\title{
ENVIRONMENTAL ASSESSMENT FOR THE WARREN STATION EXTERNALLY FIRED COMBINED CYCLE DEMONSTRATION PROJECT
}

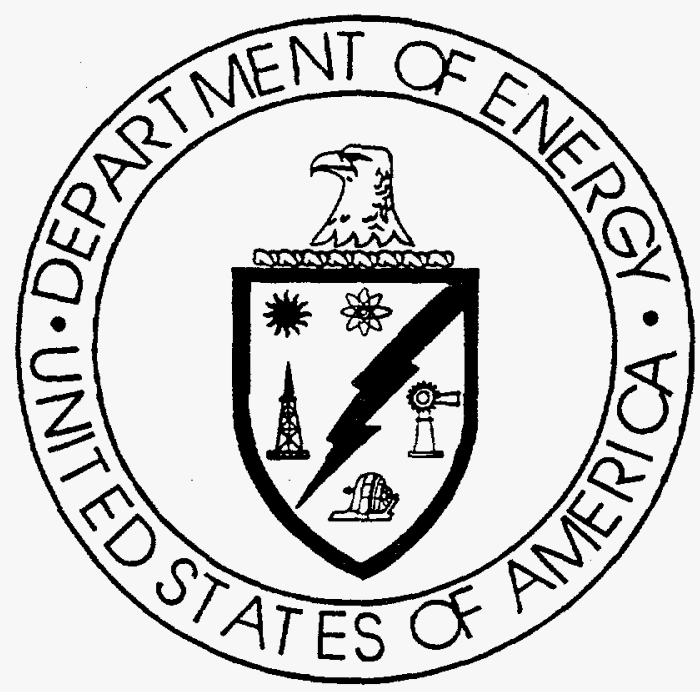

April 1995

\section{U.S. DEPARTMENT OF ENERGY}





\section{DISCLAIMER}

This report was prepared as an account of work sponsored by an agency of the United States Government. Neither the United States Government nor any agency thereof, nor any of their employees, make any warranty, express or implied, or assumes any legal liability or responsibility for the accuracy, completeness, or usefulness of any information, apparatus, product, or process disclosed, or represents that its use would not infringe privately owned rights. Reference herein to any specific commercial product, process, or service by trade name, trademark, manufacturer, or otherwise does not necessarily constitute or imply its endorsement, recommendation, or favoring by the United States Government or any agency thereof. The views and opinions of authors expressed herein do not necessarily state or reflect those of the United States Government or any agency thereof. 


\section{DISCLAIMER}

Portions of this document may be illegible in electronic image products. Images are produced from the best available original document. 


\section{TABLE OF CONTENTS}

LIST OF FIGURES $\ldots \ldots \ldots \ldots \ldots \ldots \ldots \ldots \ldots \ldots \ldots \ldots \ldots \ldots$

LIST OF TABLES $\ldots \ldots \ldots \ldots \ldots \ldots \ldots \ldots \ldots \ldots \ldots \ldots \ldots \ldots \ldots \ldots \ldots \ldots$

ACRONYMS AND ABBREVIATIONS $\ldots \ldots \ldots \ldots \ldots \ldots \ldots \ldots \ldots \ldots$ ix

1. INTRODUCTION $\ldots \ldots \ldots \ldots \ldots \ldots \ldots \ldots \ldots \ldots \ldots \ldots \ldots \ldots \ldots \ldots$

2. PURPOSE AND NEED FOR THE PROPOSED ACTION $\ldots \ldots \ldots \ldots \ldots \ldots$

3. THE PROPOSED ACTION AND ALTERNATIVES $\ldots \ldots \ldots \ldots \ldots \ldots \ldots$ 3-1

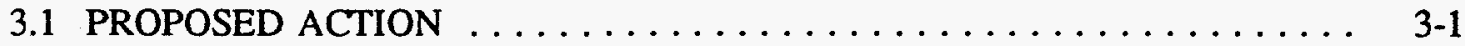

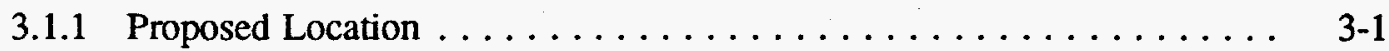

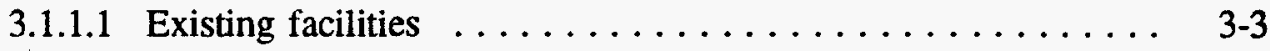

3.1.1.2 Fuel consumption, effluents, and wastes . . . . . . . . 3-3

3.1.2 Proposed Externally Fired Combined Cycle Technology . . . . . . 3 3-7

3.1.2.1 Project facilities . . . . . . . . . . . . . . . . 3-9

3.1.2.2 Process description $\ldots \ldots \ldots \ldots \ldots \ldots \ldots \ldots \ldots$ 3-9

3.1.2.3 Performance characteristics $\ldots \ldots \ldots \ldots \ldots \ldots \ldots \ldots$ 3-11

3.1.2.4 Construction activities . . . . . . . . . . . . . 3-12

3.1.2.5 Resource requirements . . . . . . . . . . . . . . . . . 3-12

3.1.2.6 Discharges and wastes ................ 3-15

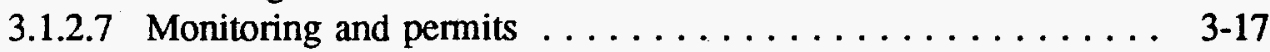

3.2 RELATED ACTIONS ... . . . . . . . . . . . . . . . . 3-19

3.3 ALTERNATIVES TO THE PROPOSED ACTION ... . . . . . . . . 3-20

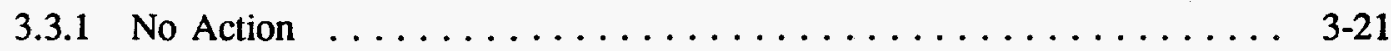

3.3.2 Alternative Technologies and Sites $\ldots \ldots \ldots \ldots \ldots \ldots \ldots$ 3-24

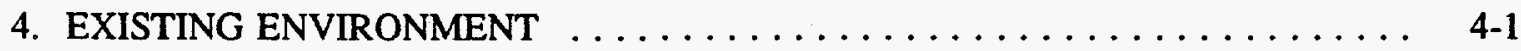

4.1 ATMOSPHERIC RESOURCES $\ldots \ldots \ldots \ldots \ldots \ldots \ldots \ldots \ldots \ldots$ 4 $4 \ldots \ldots \ldots \ldots \ldots$

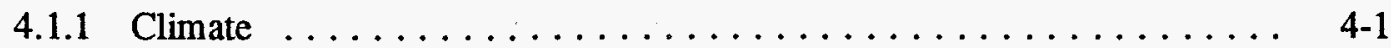

4.1 .2 Air Quality ........................... 4-3

4.2 WATER RESOURCES $\ldots \ldots \ldots \ldots \ldots \ldots \ldots \ldots \ldots \ldots \ldots \ldots$. . . . . . . . . .

4.2 .1 Surface Water Resources $\ldots \ldots \ldots \ldots \ldots \ldots \ldots \ldots \ldots$ 4-6

4.2 .2 Groundwater Resources $\ldots \ldots \ldots \ldots \ldots \ldots \ldots \ldots \ldots$ 4-8

4.2 .3 Floodplains and Wetlands . . . . . . . . . . . . . . . . 4-9

4.3 ECOLOGICAL RESOURCES . . . . . . . . . . . . . . . . . . 4-12

4.3.1 Terrestrial Ecology $\ldots \ldots \ldots \ldots \ldots \ldots \ldots \ldots \ldots \ldots . \ldots \ldots$. . . . . . . . . . . . . . . . . .

4.3 .2 Aquatic Ecology ....................... 4-13

4.3.3 Threatened and Endangered Species $\ldots \ldots \ldots \ldots \ldots \ldots \ldots . \ldots . . \ldots 44$

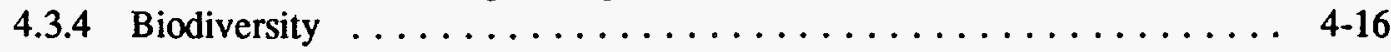

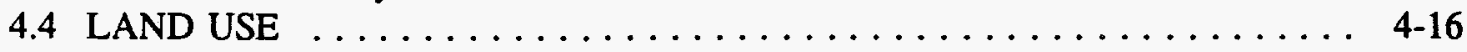

4.5 ARCHAEOLOGICAL AND CULTURAL RESOURCES . . . . . . . . . . 4-17

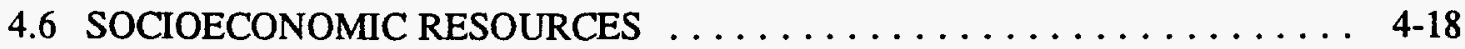

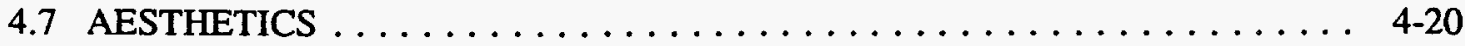

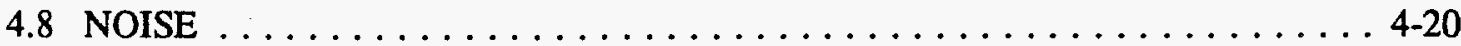


5. ENVIRONMENTAL CONSEQUENCES $\ldots \ldots \ldots \ldots \ldots \ldots \ldots \ldots \ldots \ldots$

5.1 ENVIRONMENTAL IMPACTS OF THE PROPOSED ACTION $\ldots \ldots \ldots \ldots .5-1$

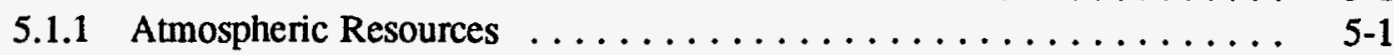

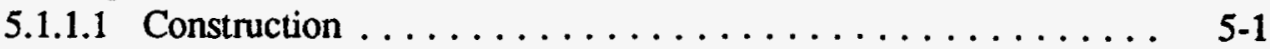

5.1 .1 .2 Operation . . . . . . . . . . . . . . . . .

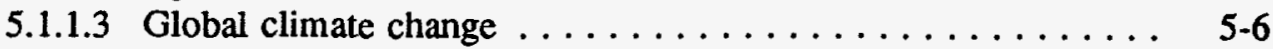

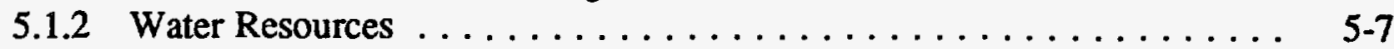

5.1.2.1 Surface water resources $\ldots \ldots \ldots \ldots \ldots \ldots \ldots \ldots \ldots . . .6$

5.1.2.2 Groundwater resources ................. 5-12

5.1.2.3 Floodplains and wetlands $\ldots \ldots \ldots \ldots \ldots \ldots \ldots \ldots$ 5-13

5.1.3 Ecological Resources ... . . . . . . . . . . . . . . . . 5-14

5.1.3.1 Terrestrial ecology $\ldots \ldots \ldots \ldots \ldots \ldots \ldots \ldots \ldots \ldots . \ldots \ldots$ 5-14

5.1.3.2 Aquatic ecology ..................... 5-15

5.1.3.3 Threatened and endangered species $\ldots \ldots \ldots \ldots \ldots \ldots \ldots$ 5-18

5.1.3.4 Biodiversity ..................... 5-19

5.1 .4 Land Use ........................ 5-19

5.1 .5 Waste Management ....................... 5-20

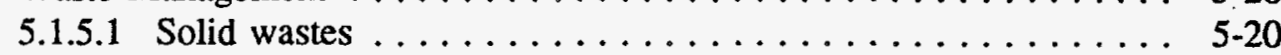

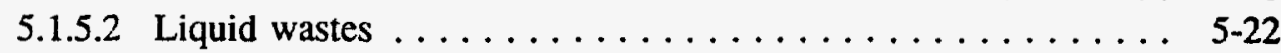

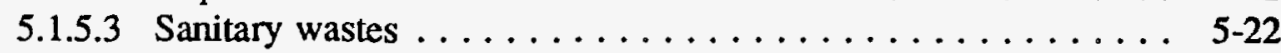

5.1 .6 Archaeological and Cultural Resources $\ldots \ldots \ldots \ldots \ldots \ldots \ldots$ 5-23

5.1 .7 Socioeconomic Resources . . . . . . . . . . . . . . . . . 5 5-24

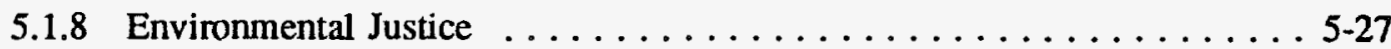

5.1 .9 Aesthetics . . . . . . . . . . . . . . . . . . . $5-28$

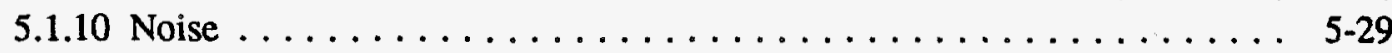

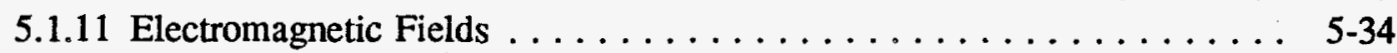

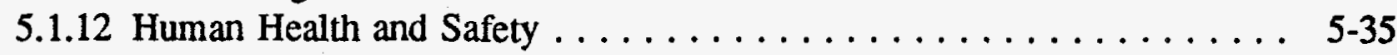

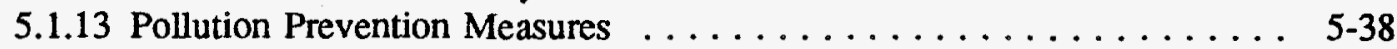

5.2 ENVIRONMENTAL IMPACTS OF NO ACTION $\ldots \ldots \ldots \ldots \ldots \ldots \ldots .5 .39$

5.3 ENVIRONMENTAL IMPACTS OF COMMERCIAL OPERATIONS ..... 541

5.4 CUMULATIVE ENVIRONMENTAL IMPACTS $\ldots \ldots \ldots \ldots \ldots \ldots \ldots .5-43$

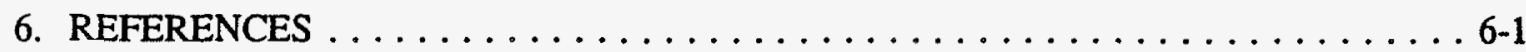

7. LIST OF AGENCIES AND PERSONS CONSULTED $\ldots \ldots \ldots \ldots \ldots \ldots \ldots \ldots$ 7-1

APPENDIX A: FISH SPECIES FOUND IN THE UPPER ALLEGHENY RIVER NEAR WARREN STATION $\ldots \ldots \ldots \ldots \ldots \ldots \ldots \ldots \ldots$ A-1

APPENDIX B: AGENCY CORRESPONDENCE $\ldots \ldots \ldots \ldots \ldots \ldots \ldots \ldots \ldots$ B-1 


\section{FIGURES}

3.1. Location of the proposed project at the existing Warren Station in northwestern Pennsylvania

3.2. Location of the proposed facility, adjacent to the existing Units 1 and $2 \ldots \ldots$ 3-6

3.3. Schematic of the externally fired combined cycle (EFCC) technology . . . . . 3-8

4.1. Wind rose for Warren Station recorded at a height of $410 \mathrm{ft} \ldots \ldots \ldots \ldots \ldots$. .

4.2. The location of the monitoring wells (MWs) at Warren Station . . . . . . 4-10

4.3. Ambient noise measurement locations near Warren Station $\ldots \ldots \ldots \ldots \ldots$ 4-22

5.1. Typical sound level ranges for construction equipment $\ldots \ldots \ldots \ldots \ldots \ldots$ 5-30

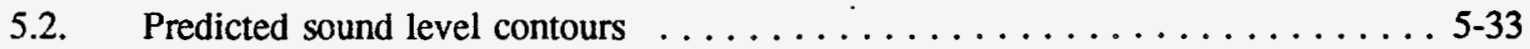





\section{TABLES}

3.1. Operating characteristics for the existing Unit 2 and the repowered Unit 2

at Warren Station . . . . . . . . . . . . . . .

3.2. Characteristics of primary test coals considered for use in the proposed Penelec project $\ldots \ldots \ldots \ldots \ldots \ldots \ldots \ldots \ldots \ldots \ldots \ldots \ldots \ldots \ldots$

3.3. Anticipated permits for the proposed Penelec project $\ldots \ldots \ldots \ldots \ldots \ldots$

3.4. Comparison of the potential environmental impacts for the proposed Penelec project versus the no-action altemative $\ldots \ldots \ldots \ldots \ldots \ldots \ldots \ldots$ 3-22

4.1. Ambient air quality monitoring data for Warren and Erie, Pennsylvania . . . . 4 4-4

4.2. Chemical characteristics of the outwash deposits aquifer and bedrock aquifer at Warren Station and in the Allegheny River valley in general . . . . 4-11

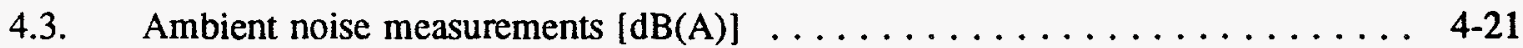

5.1. Stack and emission parameters input into the SCREEN2 model for the existing Unit 2 and the repowered Unit 2 at Warren Station $\ldots \ldots \ldots \ldots .5-4$

5.2. Maximum modeled concentrations in the ambient air from emissions of the existing Unit 2 and the repowered Unit 2 at Warren Station ....... 5-5

5.3. Composition of the peak construction work force $\ldots \ldots \ldots \ldots \ldots \ldots$

5.4. Predicted sound levels for the proposed project sources $\ldots \ldots \ldots \ldots \ldots \ldots$ 5-32

5.5. Pollution prevention measures and mitigation measures to be used during construction and operation of the proposed Penelec project $\ldots \ldots \ldots .5-40$

A.1. Fish species found in the upper Allegheny River near Warren Station . . . . . A-1 



\section{ACRONYMS AND ABBREVIATIONS}

\begin{tabular}{|c|c|}
\hline ARM & Allegheny River mile \\
\hline ASC & Air Science Consultants, Inc. \\
\hline Btu & British thermal units \\
\hline CAAA & Clean Air Act Amendments of 1990 \\
\hline $\mathrm{CCT}$ & Clean Coal Technology (Program) \\
\hline CCT-V & Clean Coal Technology (Program), fifth solicitation \\
\hline CerHx & ceramic heat exchanger \\
\hline CFR & Code of Federal Regulations \\
\hline $\mathrm{CO}$ & carbon monoxide \\
\hline $\mathrm{CO}_{2}$ & carbon dioxide \\
\hline $\mathrm{COA}$ & Consent Order and Agreement \\
\hline COE & U.S. Army Corps of Engineers \\
\hline $\mathrm{dB}(\mathrm{A})$ & decibels recorded using the A-weighted scale \\
\hline DOE & U.S. Department of Energy \\
\hline EA & Environmental Assessment \\
\hline $\mathrm{EFCC}$ & extemally fired combined cycle \\
\hline EIS & Environmental Impact Statement \\
\hline EMF & electromagnetic field \\
\hline EPA & U.S. Environmental Protection Agency \\
\hline${ }^{\circ} \mathrm{F}$ & degrees Fahrenheit \\
\hline FERC & Federal Energy Regulatory Commission \\
\hline FGD & flue gas desulfurization \\
\hline FR & Federal Register \\
\hline $\mathrm{ft}$ & foot or feet \\
\hline $\mathrm{ft}^{3} / \mathrm{s}$ & cubic feet per second \\
\hline g & gram \\
\hline gal & gallon \\
\hline gpm & gallons per minute \\
\hline h & hour \\
\hline $\mathrm{H}_{2} \mathrm{SO}_{4}$ & sulfuric acid \\
\hline HRSG & heat recovery steam generator \\
\hline ID & induced draft (fan) \\
\hline in. & inch \\
\hline $\mathbf{K}$ & Kelvin \\
\hline kV & kilovolt \\
\hline $\mathrm{kWh}$ & kilowatt-hour \\
\hline lb & pound \\
\hline$L_{d n}$ & day-night weighted sound level \\
\hline $\mathrm{L}_{\mathrm{eq}}$ & equivalent sound levels \\
\hline $\mathrm{L}_{90}$ & background noise levels \\
\hline $\mathrm{m}$ & meter \\
\hline$\mu \mathrm{g} / \mathrm{m}^{3}$ & micrograms per cubic meter \\
\hline$\mu \mathrm{m}$ & micron \\
\hline Mgd & million gallons per day \\
\hline
\end{tabular}


MMBtu million British thermal units

MMlb million pounds

MSL mean sea level

MW megawatt

NAAQS National Ambient Air Quality Standards

$\mathrm{NaOH}$ sodium hydroxide (caustic soda)

NEPA National Environmental Policy Act

$\mathrm{NO}_{2} \quad$ nitrogen dioxide

$\mathrm{NO}_{x} \quad$ oxides of nitrogen

NPDES National Pollutant Discharge Elimination System

NSC National Safety Council

OECD Organization for Economic Cooperation and Development (France)

ORNL Oak Ridge National Laboratory

OSHA Occupational Safety and Health Administration

PaDER Pennsylvania Department of Environmental Resources

PAWC Pennsylvania American Water Company

$\mathrm{Pb} \quad$ lead

PEIS Programmatic Environmental Impact Statement

PEL permissible exposure limit

Penelec Pennsylvania Electric Company

$\mathrm{pH}$ a measure of acidity: $\mathrm{pH} 0$ to $<7$ is acidic; 7 is neutral; $7+$ to 14 is alkaline

PM-10 particulate matter less than $10 \mu \mathrm{m}$ in diameter

ppm parts per million

PRWMRs Pennsylvania Residual Waste Management Regulations

PSD prevention of significant deterioration

PSIA pounds per square inch, absolute

PURTA Public Utility Realty Tax Assessment

RCRA Resource Conservation and Recovery Act

$S$ second

SCREEN2 U.S. EPA screening model for air dispersion

SIP State Implementation Plan

$\mathrm{SO}_{2} \quad$ sulfur dioxide

TDS total dissolved solids

USC U.S. Code

USGS U.S. Geological Survey

VOC volatile organic compound 


\section{INTRODUCTION}

Beginning in December 1985, Congress appropriated funding to the U.S. Department of Energy (DOE) for five separate rounds of competitive solicitations under the Clean Coal Technology (CCT) Program. As a condition of the appropriation, Congress limited DOE's funding to a maximum of $50 \%$ of the total cost of each project selected. In November 1991 , Congress passed Public Law $102-154$, which provided $\$ 600$ million to DOE for the fifth solicitation (CCT-V) under the CCT Program. The goal of CCT-V is to conduct demonstration projects that significantly advance the efficiency and environmental performance of coal technologies and that are applicable to either new or existing facilities. The solicitation emphasizes advanced, extremely clean, high-efficiency technologies that will meet the stringent post-2000 emission standards established by the Clean Air Act Amendments of 1990 (CAAA). DOE issued a Program Opportunity Notice soliciting proposals to meet this goal in June 1992. DOE's Source Evaluation Board evaluated the proposals submitted, and in May 1993, the source selection official chose five proposals as best furthering the goals and objectives of the solicitation.

For the CCT Program, DOE developed an overall, three-tiered strategy for compliance with the National Environmental Policy Act of 1969 (NEPA). This strategy is consistent with the Council on Environmental Quality regulations and the DOE regulations for NEPA compliance. First, DOE prepared a comprehensive Programmatic Environmental Impact Statement (PEIS), published in November 1989 (DOE/EIS-0146), to address the potential environmental consequences of widespread commercialization of each of 22 successfully demonstrated clean coal technologies by the year 2010. The second element in DOE's strategy involved preparing a preselection, confidential environmental review of each project based on project-specific environmental data and analyses supplied to DOE as part of the applicants' 
proposals. For this proposed project, DOE has determined that an Environmental Assessment (EA) should be prepared as the third, site-specific element of the NEPA strategy. The purpose of this EA is to provide a sufficient basis for determining whether to prepare an Environmental Impact Statement (EIS) or to issue a Finding of No Significant Impact. These documents will be publicly available.

In accordance with Council on Environmental Quality regulations, the remainder of this EA is organized into the following sections: purpose and need for the proposed action; alternatives, including the proposed action and the no-action altematives; a brief description of the affected environment; environmental consequences, including a discussion of commercial operation beyond the demonstration period; references; and a list of agencies and persons contacted. 


\section{PURPOSE AND NEED FOR THE PROPOSED ACTION}

DOE's proposed action is to provide $\$ 73$ million in federal funding (50\% of the estimated $\$ 146$ million total cost) for the design, construction, and demonstration of externally fired combined cycle (EFCC) technology. This proposed project is one of the five projects selected for potential funding under CCT-V. The costs of the proposed project would be shared by DOE and the Pennsylvania Electric Company (Penelec) under the CCT Program. The project, subsequently referred to as the Penelec project, would be constructed at Penelec's Warren Station in Warren, Pennsylvania, replacing two existing boilers. The new unit would produce about $73 \mathrm{MW}$ of electricity in a combined cycle mode of operation, which means using both gas-fired and steam turbines. DOE's decision is whether to fund the Penelec project.

The purpose of the proposed Penelec project is to demonstrate that EFCC technology is a viable candidate to meet future energy needs and is an energy-efficient technology capable of reducing emissions of sulfur dioxide $\left(\mathrm{SO}_{2}\right)$, oxides of nitrogen $\left(\mathrm{NO}_{\mathrm{x}}\right)$, and particulate matter to meet the post-2000 CAAA standards as outlined by the CCT Program goals. Data generated from the project should allow private industry to assess the potential of EFCC technology for commercial power generation.

The proposed Penelec project would fill the need for a full utility-size demonstration of the EFCC technology as the next step toward commercialization. The risk associated with advancing the EFCC technology from the current pilot stage to full commercialization is too high for the private sector to assume in the absence of strong economic incentives or legal requirements. If the technology were demonstrated as part of the cost-shared CCT Program, the risk could be reduced, and the private sector would have the data upon which to make an informed decision as to the commercial readiness of EFCC technology. 
As part of the overall NEPA strategy for the CCT Program, this EA draws upon the PEIS and preselection environmental review that analyzed many alternative technologies and their associated sites. Therefore, analysis in this EA will be limited to the technology and the site proposed by the participant. Alternatives will include options available within the planning and design of the proposed Penelec project and options reasonably foreseeable to the participant should DOE decide not to fund the project.

Detailed analyses in this EA focus on the expected level of impacts associated with atmospheric resources, water resources, and waste management. The remaining topics are analyzed to a lesser extent, commensurate with the potential for impacts on the resource area.

Sources of information upon which this EA is based include the proposal submitted by Penelec to DOE in response to the CCT-V solicitation; an Environmental Information Volume and supplemental reports submitted to DOE by Penelec; visits to the proposed site; discussions with project personnel; and coordination with federal and state agencies, specifically, the U.S. Fish and Wildlife Service (Pennsylvania District Office), the U.S. Forest Service (Allegheny National Forest), the Pennsylvania Department of Environmental Resources (PaDER), the Pennsylvania Bureau for Historic Preservation, and the Seneca Nation (New York).

In accordance with DOE's regulations implementing NEPA (10 CFR 1021.301), DOE notified the states of Pennsylvania and New York and the Seneca Nation in November 1993 of its decision to prepare an EA for the Penelec project. Copies of the EA were sent to them for review and comment in February 1995 prior to final approval. On February 22 and 25, 1995 , DOE published notices in the Warren Times Observer, a newspaper of general circulation in Warren County, Pennsylvania, that copies of the pre-approval EA were available for review and comment, either upon request from DOE or at local public reading rooms. Copies were 
available for public review in Warren, Pennsylvania, at the public library and the county courthouse and at the DOE office in Morgantown, West Virginia. Starting on February 22, 1995, the review and comment period was open for 30 days. No comments on the EA were received from the public. 


\section{THE PROPOSED ACTION AND ALTERNATIVES}

This section describes the proposed action and alternatives to the proposed action, including the no-action alternative and alternatives dismissed from further consideration.

\subsection{PROPOSED ACTION}

DOE proposes to provide $\$ 73$ million of the estimated $\$ 146$ million total cost for the design, construction, and demonstration of EFCC technology proposed by Penelec. Penelec, with team members Black \& Veatch and Hague International, proposed the project in response to DOE's CCT-V solicitation. As team members, Hague International would provide the EFCC power island equipment, and Black \& Veatch would be responsible for overall project management, design engineering, construction management, and balance-of-plant design.

\subsubsection{Proposed Location}

The proposed project would be constructed at Penelec's existing Warren Station. The station is located on 96 acres in Conewango Township, Warren County, Pennsylvania, about 1 mile west of the City of Warren. The site is bounded on the north by U.S. Highway $6 / 62$ and on the south by the Allegheny River, lying at approximately River Mile 186. The proposed site is rural in character, as evidenced by the property to the east and west of the plant boundaries. The northern border of the Allegheny National Forest is 0.8 mile south of the plant border. The closest urban areas are Erie, Pennsylvania, about 50 miles westnorthwest, and Pittsburgh, Pennsylvania, about 100 miles south-southwest (Fig. 3.1). 


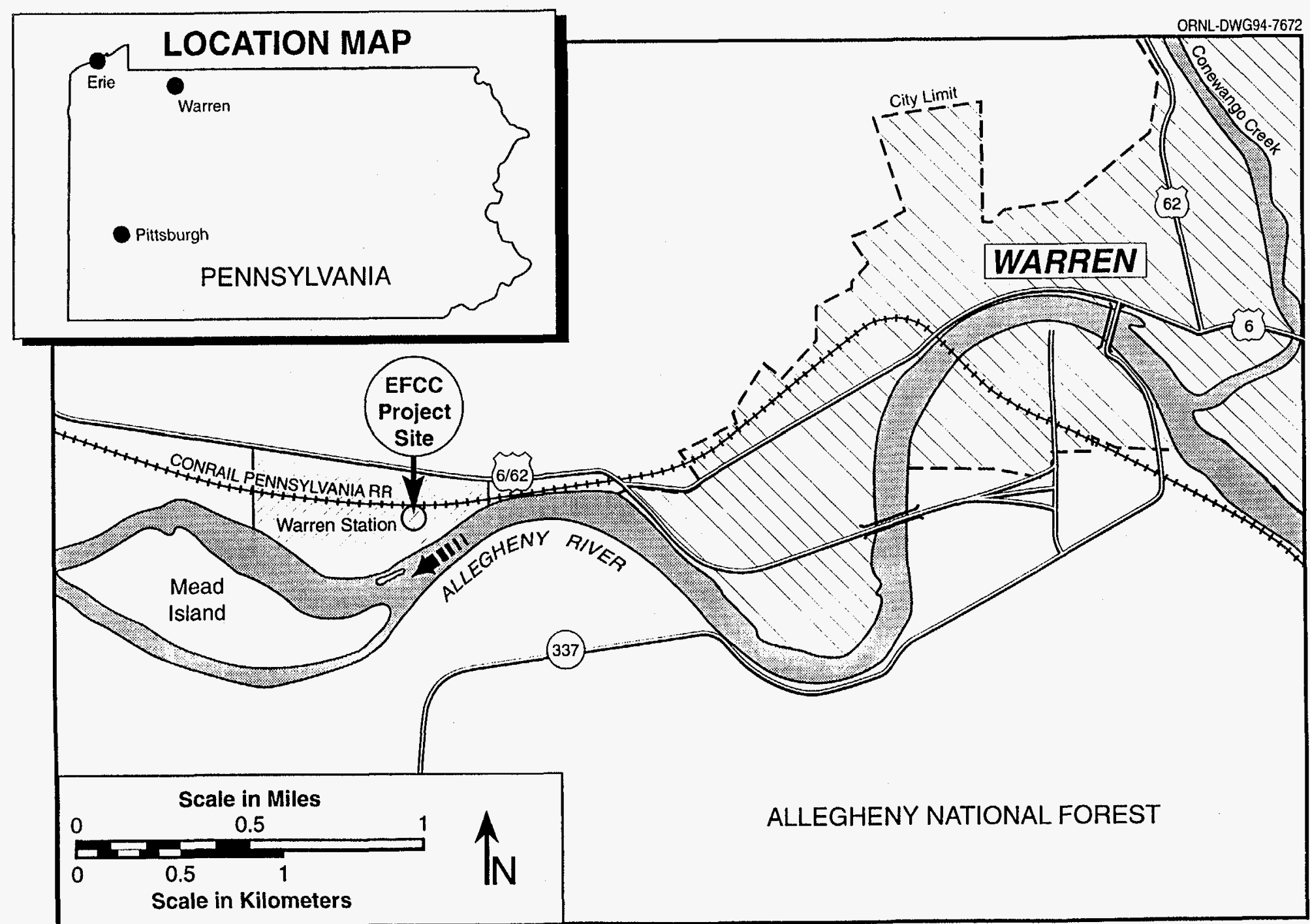

Fig. 3.1. Location of the proposed project at the existing Warren Station in northwestern Pennsylvania. 


\subsubsection{Existing facilities}

Construction and operation of the existing power station, which was built in 1948, has altered most of the 96-acre site. Warren Station has four coal-fired boilers serving two steam turbines (Units 1 and 2), which are housed in the main station building. Each turbine generates $48 \mathrm{MW}$ (gross) of electricity, for a station total of $96 \mathrm{MW}$. Each boiler is equipped with an electrostatic precipitator for particulate control. The existing $200-\mathrm{ft}$ masonry stack serves both units. Approximately 50 workers are employed at the site. Table 3.1 shows the operating characteristics and resource requirements for the power station. The existing plant layout with proposed new facilities is depicted in Fig. 3.2.

\subsubsection{Fuel consumption, effluents, and wastes}

The existing Warren Station (made up of Units 1 and 2) consumes a total of about 229,400 tons of coal per year to generate electricity. The bituminous coal has a $1.5 \%$ sulfur content, a $15 \%$ ash content, and a heating value of $12,200 \mathrm{Btu} / \mathrm{lb}$. Additionally, the power station annually uses about 163,000 gal of fuel oil during unit startup.

Actual annual air emissions at Warren Station include about 8000 tons of $\mathrm{SO}_{2}$, 1800 tons of $\mathrm{NO}_{\mathrm{x}}, 400$ tons of particulate matter, 150 tons of carbon monoxide (CO), 8 tons of volatile organic compounds (VOCs), and 578,000 tons of carbon dioxide $\left(\mathrm{CO}_{2}\right)$ (Table 3.1).

The two units contribute nearly equal amounts to the above totals.

Warren Station discharges about 58,800 gallons per minute (gpm) of heated water to the Allegheny River following once-through cooling of the turbine condensers, which results 
Table 3.1. Operating characteristics for the existing Unit 2 and the repowered Unit 2 at Warren Station (alone and in combination with Unit 1)

\begin{tabular}{|c|c|c|c|c|c|c|}
\hline Resource & Existing Unit $2^{a}$ & $\begin{array}{l}\text { Repowered } \\
\text { Unit } 2^{b}\end{array}$ & $\begin{array}{l}\text { Percent } \\
\text { change }\end{array}$ & $\begin{array}{c}\text { Existing Units } \\
1 \text { and } 2^{c}\end{array}$ & $\begin{array}{c}\text { Existing Unit } 1 \\
\text { and repowered } \\
\text { Unit } 2\end{array}$ & $\begin{array}{l}\text { Percent } \\
\text { change }\end{array}$ \\
\hline Capacity (gross), MW & 48 & 73. & +52 & 96 & 121 & +26 \\
\hline Capacity factor, $\%^{d}$ & 53 & 86 & +62 & 53 & 73 & +37 \\
\hline $\begin{array}{l}\text { Land use, acres } \\
\text { Total site area } \\
\text { Building addition }\end{array}$ & $\begin{array}{c}96 \\
0\end{array}$ & $\begin{array}{c}96 \\
1\end{array}$ & $\begin{array}{l}0 \\
-\end{array}$ & $\begin{array}{c}96 \\
0\end{array}$ & $\begin{array}{c}96 \\
1\end{array}$ & $\begin{array}{l}0 \\
-\end{array}$ \\
\hline $\begin{array}{l}\text { Fuel consumption } \\
\text { Coal, tons/year } \\
\text { Fuel oil, gal/year } \\
\text { Natural gas, } \mathrm{ft}^{3} / \text { year }\end{array}$ & $\begin{array}{c}115,300 \\
81,500 \\
0\end{array}$ & $\begin{array}{c}185,500 \\
0 \\
14,000,000\end{array}$ & $\begin{array}{l}+61 \\
-100 \\
-\end{array}$ & $\begin{array}{c}229,400 \\
163,000 \\
0\end{array}$ & $\begin{array}{c}299,600 \\
81,500 \\
14,000,000\end{array}$ & $\begin{array}{l}+31 \\
-50 \\
-\end{array}$ \\
\hline Total water consumption, gallons per minute (gpm) & 30,220 & $\leq 30,327$ & +0.4 & 60,440 & $\leq 60,547$ & +0.2 \\
\hline $\begin{array}{l}\text { Total water obtained from the Allegheny River } \\
\text { Condensers } \\
\text { Ash disposal } \\
\text { Flue gas desulfurization } \\
\text { Evaporators }\end{array}$ & $\begin{array}{c}30,218 \\
29,400 \\
800 \\
0 \\
18\end{array}$ & $\begin{array}{c}\leq 30,253 \\
29,400 \\
\leq 800 \\
53 \\
0\end{array}$ & $\begin{array}{c}+0.1 \\
0 \\
0 \\
- \\
-100\end{array}$ & $\begin{array}{c}60,436 \\
58,800 \\
1,600 \\
0 \\
36\end{array}$ & $\begin{array}{c}\leq 60,471 \\
58,800 \\
\leq 1,600 \\
53 \\
18\end{array}$ & $\begin{array}{c}+0.06 \\
0 \\
0 \\
- \\
-50\end{array}$ \\
\hline $\begin{array}{l}\text { Total water obtained from the PAWC } \\
\text { Demineralizer } \\
\text { Potable }\end{array}$ & $\begin{array}{l}2 \\
0 \\
2\end{array}$ & $\begin{array}{c}74 \\
72 \\
2\end{array}$ & $\begin{array}{c}+3600 \\
- \\
0\end{array}$ & $\begin{array}{l}4 \\
0 \\
4\end{array}$ & $\begin{array}{c}76 \\
72 \\
4\end{array}$ & $\begin{array}{c}+1800 \\
- \\
0\end{array}$ \\
\hline Lime consumption, tons/year & 0 & 10,000 & - & 0 & 10,000 & - \\
\hline Sulfuric acid consumption, tons/year & 0 & 33 & - & 0 & 33 & - \\
\hline Sodium hydroxide consumption, tons/year & 157 & 135 & -14 & 314 & 292 & -7 \\
\hline Aluminum sulfate consumption, tons/year & 0.5 & 1 & +100 & 1 & 1.5 & +50 \\
\hline Hydrazine consumption, gal/year & 20 & 20 & 0 & 40 & 40 & 0 \\
\hline Sodium phosphate consumption, gal/year & 40 & 40 & 0 & 80 & 80 & 0 \\
\hline Morpholine consumption, lb/year & 100 & 100 & 0 & 200 & 200 & 0 \\
\hline
\end{tabular}


Table 3.1 (continued)

\begin{tabular}{|c|c|c|c|c|c|c|}
\hline Resource & Existing Unit $2^{a}$ & $\begin{array}{c}\text { Repowered } \\
\text { Unit } 2^{b} \\
\end{array}$ & $\begin{array}{l}\text { Percent } \\
\text { change }\end{array}$ & $\begin{array}{c}\text { Existing Units } \\
1 \text { and } 2^{c} \\
\end{array}$ & $\begin{array}{c}\text { Existing Unit } 1 \\
\text { and repowered } \\
\text { Unit } 2 \\
\end{array}$ & $\begin{array}{l}\text { Percent } \\
\text { change }\end{array}$ \\
\hline \multicolumn{7}{|l|}{ Air emissions, tons/year } \\
\hline $\begin{array}{l}\text { Sulfur dioxide } \\
\text { Nitrogen oxides }\end{array}$ & $\begin{array}{c}3,982 \\
886\end{array}$ & $\begin{array}{l}821 \\
602 z^{2}\end{array}$ & $\begin{array}{r}-79 \\
-72\end{array}$ & $\begin{array}{l}7,964 \\
777\end{array}$ & $\begin{array}{l}4,803 \\
1,80\end{array}$ & $\begin{array}{l}-40 \\
-16\end{array}$ \\
\hline Particulate matter & 190 & 73 & -62 & 380 & 263 & -31 \\
\hline Carbon monoxide & 76 & $f$ & - & 152 & $f$ & - \\
\hline Volatile organic compounds & 4.1 & 3 & -27 & 8.2 & 7.1 & -13 \\
\hline Carbon dioxide & 289,000 & 495,000 & +71 & 578,000 & 784,000 & +36 \\
\hline \multicolumn{7}{|l|}{ Liquid effluents, gpm } \\
\hline Wastewater discharges & 800 & $\leq 800$ & 0 & 1,600 & $\leq 1,600$ & 0 \\
\hline Cooling water & 29,400 & 29,400 & 0 & 58,800 & 58,800 & 0 \\
\hline Total solid waste, tons/year & 10,500 & $35,230^{8}$ & +236 & 21,000 & 45,730 & +118 \\
\hline Bottom ash & 2,100 & 4,510 & +115 & 4,200 & 6,610 & +57 \\
\hline Scrubber waste & 0 & 15,820 & - & 0 & 15,820 & - \\
\hline Fly ash and other entrained particulate matter & 8,400 & 14,900 & +77 & 16,800 & 23,300 & +39 \\
\hline
\end{tabular}

Source: ASC 1993.

Based on $4620 \mathrm{~h}$ of operation per year at full load, which approximates historical operating conditions for Unit 2.

Based on $7500 \mathrm{~h}$ of operation per year at full load at $47.1^{\circ} \mathrm{F}, 60 \%$ relative humidity, and 14.03 psia, using primary test coal \#1 with 30 starts per year (ASC 1993 , Appendix C)

'Based on $4620 \mathrm{~h}$ of operation per year at full load, which approximates historical operating conditions for Units 1 and 2.

${ }^{d}$ Capacity factor is the ratio of the energy output during a period of time to the energy that would have been produced if the equipment had operated at its maximum power during that period.

Based on emissions of $0.25 \mathrm{lb} / \mathrm{MMBtu}$, a value that forms an upper bound of expected emissions. The Reasonably Available Control Technology analysis for the project used a value of $0.15 \mathrm{lb} M M \mathrm{~b} t u$, which is anticipated to be closer to actual emissions, but does not form an upper bound.

The predicted annual emissions are unknown. The emissions of carbon monoxide from the repowered Unit 2 are expected to be lower than those from the existing Unit 2 (ASC 1993).

Solid waste was calculated assuming the repowered Unit 2 would operate at full load using primary test coal \#1 with $8.1 \%$ ash content.

PAWC = Pennsylvania American Water Company. 


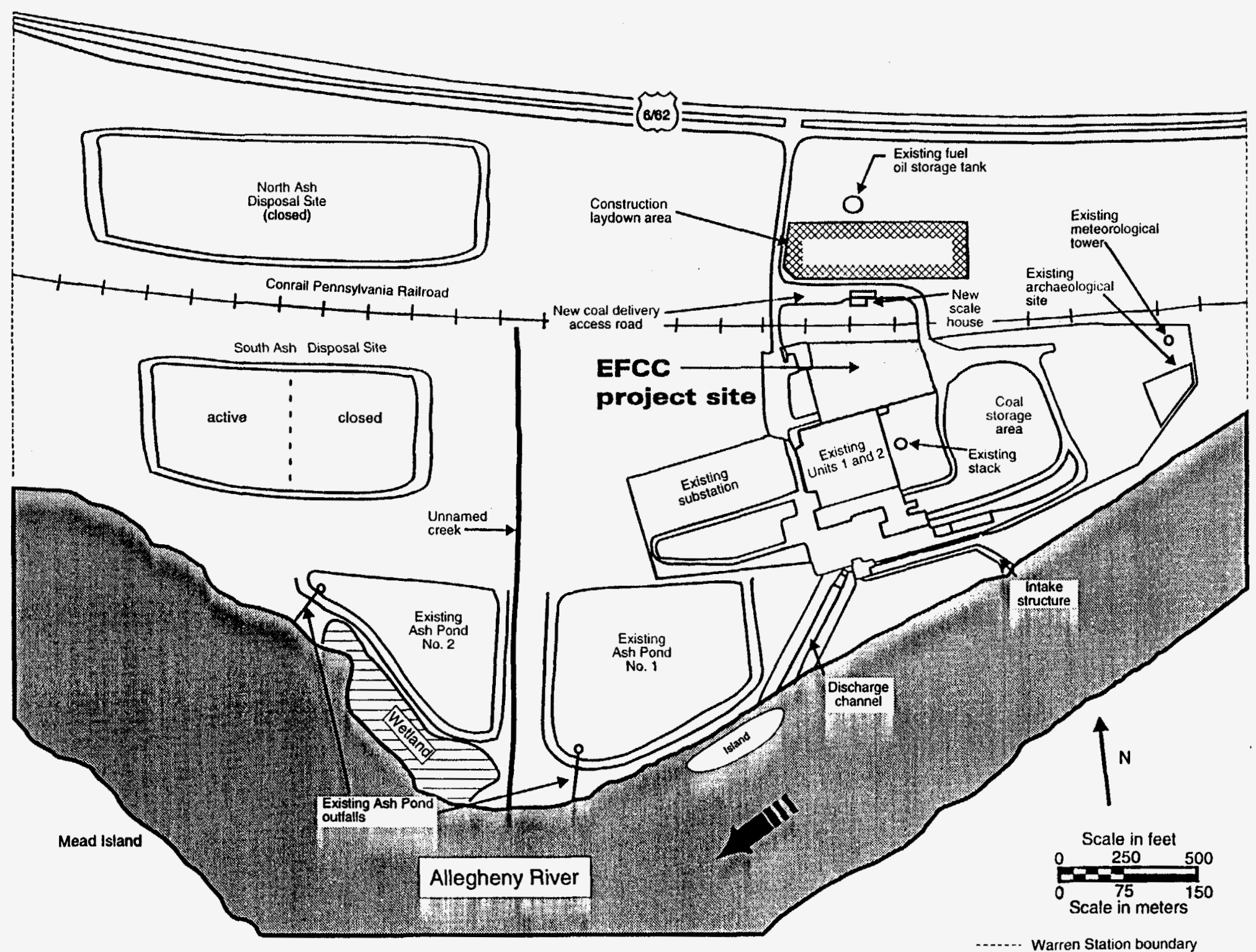

Fig. 3.2. Location of the proposed facility, adjacent to the existing Units 1 and 2 . 
in a thermal plume in the river. The heat rejection rate to the river is within the National Pollutant Discharge Elimination System (NPDES) permit limit of $186,780 \mathrm{Kw}(15,306 \times$ $\left.10^{6} \mathrm{Btu} / \mathrm{day}\right)$. In addition, the power station discharges about $1600 \mathrm{gpm}$ of wastewater from one of two unlined ash ponds into the Allegheny River. The wastewater is used primarily to sluice fly ash and bottom ash to the ash ponds.

Warren Station annually generates about 16,800 tons of fly ash and 4200 tons of bottom ash for a total of 21,000 tons. As shown in Fig. 3.2, there are two unlined on-site ash disposal areas (landfills): the North Ash Disposal Site (closed in 1985), and the South Ash Disposal Site (the eastem half of which was closed in 1992). Fly ash and bottom ash that have been sluiced to the ash ponds are later moved to the active portion of the South Ash Disposal Site.

\subsubsection{Proposed Externally Fired Combined Cycle Technology}

For the proposed Penelec project, a new "power island" consisting of a staged coal combustor, slag screen, ceramic heat exchanger (CerHx), indirectly fired gas turbine, and heat recovery steam generator (HRSG) would replace two existing boilers (Fig. 3.3). Subsequently, Unit 2 would operate in combined-cycle mode using the new gas turbine and the existing steam turbine simultaneously. The gas turbine would generate $25 \mathrm{MW}$ of electricity so that Unit 2 output would increase from the existing $48 \mathrm{MW}$ (generated in the steam turbine) to a total of $73 \mathrm{MW}$ (gross). The two existing boilers would not be dismantled but would be rendered unusable. 


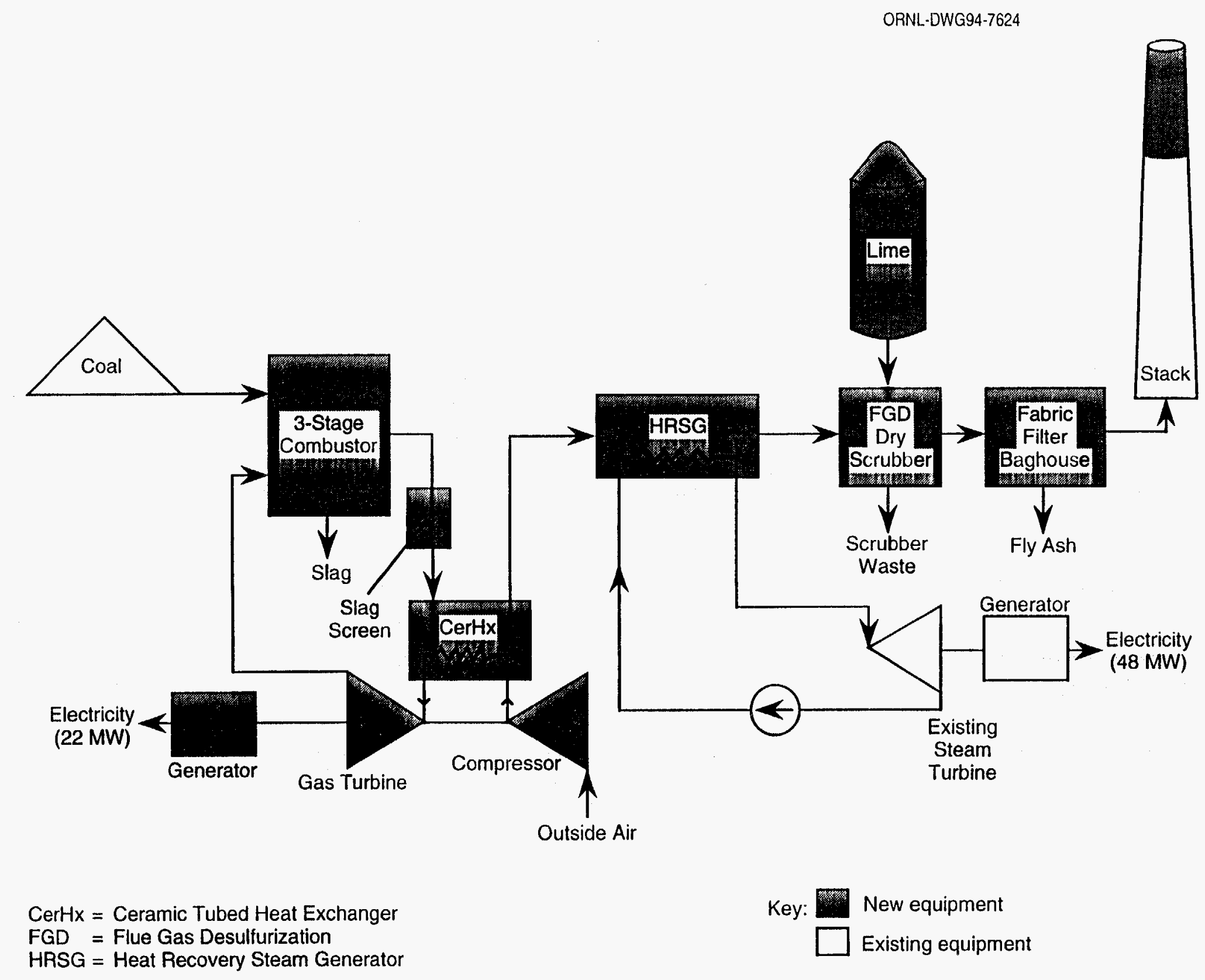

Fig. 3.3. Schematic of the externally fired combined cycle (EFCC) technology. 


\subsubsection{Project facilities}

Major new equipment for the proposed project would include the combustor, slag screen, CerHx, gas turbine and its compressor and electric generator, HRSG, lime silo, flue gas desulfurization (FGD) dry scrubber, and baghouse (Fig. 3.3). The existing steam turbine, its electric generator, and the stack would be integrated with the new equipment (Fig. 3.3). The $200-\mathrm{ft}$ stack would be extended by $112 \mathrm{ft}$ to a new height of $312 \mathrm{ft}$.

Figure 3.2 shows the general layout of the proposed facilities. Most of the new EFCC components would be housed in a new 270 - $\mathrm{ft}$ by 150 - $\mathrm{ft}$ addition located on the northem edge of the existing building that houses Units 1 and 2 . A $50-\mathrm{ft}$ by $25-\mathrm{ft}$ water treatment facility would be located on the northern edge of the new addition. The new lime silo would be located in the northeastern comer of the new addition. New generator transformers would be located near the existing substation. The project would use the existing coal storage and receiving facilities. The coal-handling system would be extended to accommodate the proposed project.

\subsubsection{Process description}

Figure 3.3 illustrates the EFCC process to be demonstrated at Warren Station. A conveyor transports pulverized coal into the top of the coal combustor. In the three-stage combustor, gas turbine exhaust air and outside air are carefully mixed to provide combustion temperature control. The amount of $\mathrm{NO}_{\mathrm{x}}$ emissions generated during staged combustion $(0.25 \mathrm{lb} / \mathrm{MMBtu})$ is about $40 \%$ of the amount typically generated during uncontrolled 
combustion. $\mathrm{CO}$ emissions are also lower because the bumers in the combustor are arranged to optimize carbon burnout.

The hot combustion gas exits the lower section of the combustor and enters a slag screen, which is composed of an array of ceramic rods. As the combustion gas flows through the slag screen, ash particles larger than $10 \mu \mathrm{m}$ are removed as they impact and stick to the ceramic rods. Periodically, ash is removed from the rods and quenched in a water pit.

The hot combustion gas exits the slag screen and enters the CerHx. In the CerHx, heat from the combustion gas passes through the walls of ceramic tubes and warms air that has been drawn from outside and pressurized in the compressor. This clean, hot, pressurized air is then expanded through the gas turbine to produce $25 \mathrm{MW}$ of electricity in its generator. This is the central feature of the EFCC technology. In this way, costly turbine components are not exposed to the corrosive and abrasive substances in the combustor exhaust gas. Instead, clean air, heated in the CerHx by the exhaust gas from the combustor, is expanded through the gas turbine. Additional efficiency is achieved by sending the exhaust air from the gas turbine to the combustor, where it serves as preheated air.

Combustion gas discharged from the CerHx enters the HRSG, where a portion of its remaining heat is used to generate steam. This steam is then expanded in the existing steam turbine to produce $48 \mathrm{MW}$ of electricity in its generator.

Combustion gas exiting the HRSG enters the FGD dry scrubber for $\mathrm{SO}_{2}$ removal. In the scrubber, $\mathrm{SO}_{2}$ reacts with lime to form calcium sulfate and calcium sulfite, which are removed at the bottom of the scrubber. An $80 \%$ reduction of $\mathrm{SO}_{2}$ in the combustion gas is achieved in this process step. The combustion gas stream exits the scrubber carrying particulate matter including fly ash, excess lime, and excess calcium sulfate and calcium sulfite. The gas then 
passes through the pulse-jet fabric filter baghouse where these solids are collected. An additional $10 \%$ reduction of $\mathrm{SO}_{2}$ is attained through the collection of sulfurous solids in the baghouse, yielding a total of $90 \% \mathrm{SO}_{2}$ removal from the combustion gas stream. Remaining $\mathrm{SO}_{2}$ in the gas stream would be limited to $0.34 \mathrm{lb} / \mathrm{MMBtu}$. Likewise, the baghouse is expected to limit particulate emissions to $0.03 \mathrm{lb} / \mathrm{MMBtu}$ and opacity to less than $20 \%$. The combustion gas would be discharged through Warren Station's existing stack (raised to a height of $312 \mathrm{ft}$ ).

\subsubsection{Performance characteristics}

The repowered Unit 2 is expected to achieve an approximate $50 \%$ increase in maximum power generation with the EFCC technology (73 MW for the repowered Unit 2 vs $48 \mathrm{MW}$ for the existing Unit 2). Because the EFCC technology is more efficient, this increase in power generation would be achieved using nearly the same amount of coal per hour as the existing Unit 2. However, annual operating time for the repowered Unit 2 is expected to increase by about $60 \%$ over the existing Unit 2's $4620 \mathrm{~h}$ (based on 1992 operating conditions) to $7500 \mathrm{~h}$ out of a possible $8760 \mathrm{~h}$ per year (ASC 1993). Consequently, annual coal consumption would also increase by about $60 \%$ from 115,300 tons for the existing Unit 2 to 185,500 tons for the repowered Unit 2. Other operating characteristics also are based on this increase in operating time for the repowered Unit 2 (Table 3.1).

To form an upper bound on expected operating time of the 48-MW Unit 1, it is assumed that the unit would continue to operate about $4650 \mathrm{~h}$ per year (1992 operating conditions) at the same power level. In actuality, Unit 1 may operate less than $4650 \mathrm{~h}$ per year 
in the future because it is less efficient than the repowered Unit 2 and many other units in the Penelec system.

The percentage change in operating characteristics at Warren Station as a whole would be half the percentage change considering Unit 2 alone. For example, maximum power generation at Warren Station would increase by about 25\% (121 MW vs $96 \mathrm{MW}$ ), and annual coal consumption would increase by about $30 \%$ (299,600 tons vs 229,400 tons) (Table 3.1$)$.

\subsubsection{Construction activities}

Construction of the proposed Penelec project is tentatively scheduled to start in August 1995 and continue for about 21 months. The 30-month demonstration period is expected to start in May 1997. Following the demonstration period, Penelec expects to operate the repowered Unit 2 as a commercial unit, independent of DOE funding, through 2012.

\subsubsection{Resource requirements}

Resource requirements for the proposed Penelec project are compared with those of the existing Unit 2 in Table 3.1; also, resource requirements for the proposed project combined with the existing Unit 1 are compared with those of the existing Warren Station (Units 1 and 2).

The proposed project would require about 25 tons of coal per hour to generate $73 \mathrm{MW}$ (gross) of electricity. Auxiliary equipment would consume about $4 \mathrm{MW}$ of the $73 \mathrm{MW}$. The proposed project would use about 185,500 tons of coal per year. Added to the 114,100 tons of 
coal used by Unit 1 in 1992 , the total annual amount of coal used at Warren Station would be 299,600 tons. The additional 70,200 tons of coal per year $(299,600$ tons vs 229,400 tons for the existing Warren Station) would be supplied by four counties in central and western Pennsylvania. The coal would be delivered by an additional 70 trucks per week. Table 3.2 displays the heating value, sulfur content, and ash content of the two primary test coals that have been considered for use in the proposed project.

Table 3.2. Characteristics of primary test coals considered for use in the proposed Penelec project

\begin{tabular}{lcc}
\hline \multicolumn{1}{c}{ Characteristic } & Primary test coal 1 & Primary test coal 2 \\
\hline Heating value, Btu/lb & 12,999 & 12,043 \\
Sulfur content, \% & 2.2 & 0.9 \\
Ash content, \% & 8.1 & 11.1 \\
\hline
\end{tabular}

Source: ASC (1993), Appendix E.

Water drawn from the Allegheny River would be used for the existing Unit 1 and Unit 2 condensers, the new FGD scrubber, a new demineralizer, and ash transfer. The amount of water drawn for the condensers would remain the same at $58,800 \mathrm{gpm}$ for Warren Station. The amount of water required for sluicing to the ash ponds is expected to decrease because the fly ash from Unit 2 would no longer be sluiced to the ash ponds. An additional $53 \mathrm{gpm}$ of water for the FGD scrubber would be required, while the existing Unit 2 evaporator would no longer require the current $18 \mathrm{gpm}$. A demineralizer would replace the existing Unit 2 evaporator and would require $72 \mathrm{gpm}$ obtained from the Pennsylvania American Water Company (PAWC), which draws water from the Allegheny River upstream of Warren Station in Warren. 
No land acquisition would be necessary for the proposed project. Construction of the project, including associated buildings and equipment, would occur within the existing plant boundaries. Solid waste associated with the project would be disposed of on land currently used for that purpose.

Small amounts of natural gas would be used during testing and startup of the combustor and gas turbine. Assuming $500 \mathrm{~h}$ of operation on natural gas during the first year, 14 million $\mathrm{ft}^{3} /$ year would be used (ASC 1993). Use of natural gas would likely decrease in subsequent years. Fuel oil used for Unit 1 startup would remain unchanged; however, the repowered Unit 2 would use no fuel oil.

In addition to natural gas, new materials required for the proposed project include lime and sulfuric acid $\left(\mathrm{H}_{2} \mathrm{SO}_{4}\right)$. The FGD scrubber would use about 10,000 tons of lime annually. About nine trucks per week would deliver lime from Centre County, Pennsylvania, or Ashtabula County, Ohio. The new lime storage silo would accommodate a 1-week supply. The new demineralizer would use 33 tons per year of $\mathrm{H}_{2} \mathrm{SO}_{4}$ (equivalent to $5110 \mathrm{gal}$ ). A new 1000-gal tank would store the $\mathrm{H}_{2} \mathrm{SO}_{4}$. The tank would be filled five or six times per year.

The demineralizer would also use about 135 tons per year of sodium hydroxide $(\mathrm{NaOH})$ (equivalent to $6570 \mathrm{gal}$ ). The $\mathrm{NaOH}$ used in the demineralizer would be stored and prepared in existing tanks already used to store $\mathrm{NaOH}$ for coal pile runoff and ash disposal treatment. The amount of $\mathrm{NaOH}$ used at Warren Station would decrease by about $10 \%$ from current levels.

The annual use of $40 \mathrm{gal}$ of hydrazine, $80 \mathrm{gal}$ of sodium phosphate, and $200 \mathrm{lb}$ of morpholine in the boiler feedwater treatment system would remain unchanged. Aluminum sulfate usage to clarify house water would be about 1.5 tons per year, which is $50 \%$ greater than the amount currently used at Warren Station. The quantities of bentonite clay used to 
clarify house water and rock salt used to soften water would each drop by $50 \%$. The above chemicals would be transported by truck to Warren Station. All chemicals would be properly labeled and stored according to fire codes and Occupational Safety and Health Administration (OSHA) requirements.

\subsubsection{Discharges and wastes}

This section discusses discharges and wastes that would result from the proposed Penelec project. Table 3.1 summarizes anticipated discharges and wastes associated with the project.

During the demonstration, annual air emissions from the repowered Unit 2 would include approximately 821 tons of $\mathrm{SO}_{2}, 603$ tons of $\mathrm{NO}_{\mathrm{x}}, 73$ tons of particulate matter, 3 tons of VOCs, and 495,000 tons of $\mathrm{CO}_{2}$. As a consequence of the project, annual $\mathrm{SO}_{2}$ emissions for Warren Station as a whole would decrease by about $40 \%$ from 7964 tons to 4803 tons. Annual $\mathrm{NO}_{\mathrm{x}}$ emissions would be reduced by about $16 \%$ from 1772 tons to 1489 tons. Annual particulate emissions would decrease by about $31 \%$ from 380 tons to 263 tons. Annual VOC emissions would be lowered by about $13 \%$ from 8 tons to 7 tons. Annual $\mathrm{CO}_{2}$ emissions would increase by about $36 \%$ from 578,000 tons to 784,000 tons.

During the proposed project, a total of 58,800 gpm of heated water would continue to be discharged to the Allegheny River from the Warren Station condensers. The proposed project would not affect the heat discharge rate to the river. Wastewater would continue to be discharged from the ash sluicing system, the truck hopper sump, and the plant sump into one of the two existing ash ponds located at Warren Station. The EFCC demineralizer would 
release about $8 \mathrm{gpm}$ of wastewater to the plant sump, which in tum discharges to the ash ponds. The EFCC steam cycle would also discharge about $8 \mathrm{gpm}$ of condensate to the plant sump. Solids settle to the bottom of the ash ponds and are periodically removed to the ash disposal area. The existing discharge rate of $1600 \mathrm{gpm}$ from the Warren Station ash ponds into the Allegheny River is expected to decrease because the fly ash from Unit 2 would no longer be sluiced to the ash ponds. Most of the $53 \mathrm{gpm}$ of river water required by the FGD scrubber would be discharged to the atmosphere as water vapor. A small fraction would be absorbed by the ash and lime sorbent in the flue gas. Sanitary wastes would continue to flow to the existing septic system at the rate of $4 \mathrm{gpm}$ and discharge without treatment to the existing leachate field.

The repowered Unit 2 would generate about 35,200 tons of solid waste per year. Solid waste for Warren Station as a whole would increase by about $118 \%$ from 21,000 tons per year to 45,700 tons per year. This increase would be a result of Unit 2's increased operating hours and the additional solid waste collected by Unit 2's FGD scrubber and baghouse. Approximately $87 \%$ of Unit 2's waste would be fly ash and scrubber waste (such as spent lime sorbent) collected by the FGD scrubber and baghouse, and $13 \%$ would be bottom ash. As in current operations, fly ash and bottom ash from Unit 1 and bottom ash from Unit 2 would be sluiced to the ash ponds and eventually disposed of in the on-site landfill. However, Unit 2's fly ash and scrubber waste would be trucked directly to the on-site landfill. Therefore, half of the existing 16,800 tons of fly ash generated annually by Warren Station would no longer be conveyed to the ash ponds.

For hazardous chemicals, an approved spill prevention and countermeasures plan would be prepared that would specify storage location, cleanup methods, training, and inspection 
procedures. The $\mathrm{H}_{2} \mathrm{SO}_{4}$ tank would have secondary containment to control accidental spillage. Waste produced from using $\mathrm{H}_{2} \mathrm{SO}_{4}$ would be neutralized with an equivalent amount of $\mathrm{NaOH}$ in the wastewater treatment system before discharge into the Allegheny River. Similarly, waste produced from using $\mathrm{NaOH}$ would be neutralized with an equivalent amount of $\mathrm{H}_{2} \mathrm{SO}_{4}$. Morpholine, hydrazine, and sodium phosphate would continue to be stored in areas surrounded by curbing; minor spills would be routed to the wastewater treatment system for treatment before discharge into the Allegheny River. Major spills would be cleaned up in a timely manner and disposed of off-site in accordance with appropriate regulations. Compliance with the Emergency Planning and Community Right-to-Know Act of 1986 (40 CFR 355 , Appendix A) would be achieved by informing appropriate individuals in the surrounding community of reportable quantities of chemicals stored at Warren Station.

\subsubsection{Monitoring and permits}

Continuous emission monitoring for $\mathrm{SO}_{2}, \mathrm{NO}_{x}, \mathrm{CO}_{2}$, and opacity, which is currently conducted in the Warren Station stack, would be expanded with the proposed Penelec project. The additional monitoring would detect the greater range in emission values as a result of lower emissions from the repowered Unit 2. As is currently done, liquid discharged into the Allegheny River would be monitored under the proposed project. Specifically, total suspended solids, $\mathrm{Ph}$ level, and oil and grease samples would be taken weekly at the ash pond discharge. Heat and flow rate of the liquid discharge would be monitored continuously.

Most permits would need to be modified for the proposed project (Table 3.3). The existing air permit would be updated to include approval of the new pollution control 
Table 3.3. Anticipated permits for the proposed Penelec project

\begin{tabular}{llll}
\hline Agency & Permit/citation & Reason required & Comments \\
\hline
\end{tabular}

State permits

\begin{tabular}{|c|c|c|c|}
\hline PaDER & $\begin{array}{l}\text { Air Quality Plan Approval } \\
25 \text { Pa. Code } \$ 127 \\
40 \text { CFR } \$ 52\end{array}$ & $\begin{array}{l}\text { Approval to allow } \\
\text { construction and startup }\end{array}$ & $\begin{array}{l}\text { Approval of air } \\
\text { pollution control } \\
\text { equipment being } \\
\text { installed }\end{array}$ \\
\hline PaDER & $\begin{array}{l}\text { National Pollutant } \\
\text { Discharge } \\
\text { Elimination System } \\
\text { (NPDES) Permit; } 25 \text { Pa. } \\
\text { Code } \$ 92 ; 40 \text { CFR } \$ 122\end{array}$ & $\begin{array}{l}\text { Discharge of industrial } \\
\text { wastewater into surface } \\
\text { waters }\end{array}$ & $\begin{array}{l}\text { Notification of process } \\
\text { changes for existing } \\
\text { permit No. } 0005053\end{array}$ \\
\hline PaDER & $\begin{array}{l}\text { Solid Waste Disposal } \\
\text { and/or Processing Facility } \\
\text { Permit; } \\
25 \mathrm{~Pa} \text {. Code } \$ 75\end{array}$ & $\begin{array}{l}\text { On-site disposal of ash } \\
\text { and scrubber waste }\end{array}$ & $\begin{array}{l}\text { Modification of } \\
\text { existing permit } \\
\text { No. } 300858\end{array}$ \\
\hline PaDER & $\begin{array}{l}\text { Earth Disturbance Permit } \\
25 \mathrm{~Pa} \text {. Code } \S 102.31\end{array}$ & $\begin{array}{l}\text { Disturbance of ground } \\
\text { surface }\end{array}$ & $\begin{array}{l}\text { Required if disturbing } \\
5 \text { or more acres }\end{array}$ \\
\hline PaDER & $\begin{array}{l}\text { Erosion and Sediment } \\
\text { Control Permit } \\
35 \mathrm{~Pa} \text { \& } 691.202 \text { et seq. }\end{array}$ & $\begin{array}{l}\text { Control of erosion during } \\
\text { construction }\end{array}$ & $\begin{array}{l}\text { Approval of soil } \\
\text { erosion plans }\end{array}$ \\
\hline $\begin{array}{l}\text { Pa. Dept. of } \\
\text { Labor }\end{array}$ & $\begin{array}{l}\text { Building Approval } \\
\text { Fire and Panic Code } \\
\text { Occupancy Permit } \\
\text { 34 Pa. Code Chapters } \\
\text { 49-59 }\end{array}$ & Means of building egress & $\begin{array}{l}\text { Permit issued after } \\
\text { final inspection }\end{array}$ \\
\hline $\begin{array}{l}\text { Pa. Dept. of } \\
\text { Labor }\end{array}$ & $\begin{array}{l}\text { Lifting Devices-Elevators } \\
34 \mathrm{~Pa} \text {. Code Chapter } 7\end{array}$ & Approv & $\begin{array}{l}\text { Required for any new } \\
\text { elevator }\end{array}$ \\
\hline
\end{tabular}

Local permit

\begin{tabular}{|c|c|}
\hline $\begin{array}{l}\text { Warren } \\
\text { County }\end{array}$ & $\begin{array}{l}\text { Zoning ordinance as } \\
\text { amended }\end{array}$ \\
\hline
\end{tabular}

PaDER = Pennsylvania Department of Environmental Resources.

$\mathrm{Pa} .=$ Commonwealth of Pennsylvania.

$\mathrm{CFR}=$ Code of Federal Regulations. 
equipment that would be installed. The NPDES permit would also require modification to include notification of process changes affecting liquid discharge. The solid waste disposal and/or processing facility permit would require updating to account for additional on-site disposal of ash and spent lime sorbent. Other local construction permits would be required.

\subsection{RELATED ACTIONS}

Penelec has undertaken three actions at Warren Station independent of the proposed action. The first two actions result from regulatory revisions that affect the existing station. The third action is being conducted to increase the reliability of Penelec's power generation system.

1. The CAAA requires each state to revise its State Implementation Plan (SIP) to outline procedures for bringing all nonattainment areas into compliance with the National Ambient Air Quality Standards (NAAQS) and for preventing significant air quality deterioration in attainment areas. Conewango Township is currently designated as being in nonattainment for $\mathrm{SO}_{2}$ in the ambient air. The nonattainment designation, which has been in effect since 1977 , was based on modeling predictions of ambient concentrations resulting from Warren Station emissions. As an important component of the SIP revision, Penelec and PaDER established a Consent Order and Agreement (COA) in April 1993 to reevaluate the air quality status resulting from $\mathrm{SO}_{2}$ emissions at Warren Station and to establish $\mathrm{SO}_{2}$ emission limits that will ensure attainment of the NAAQS. In the meantime, Warren Station has been operating under an interim $\mathrm{SO}_{2}$ emission limit of $3.0 \mathrm{lb} / \mathrm{MMBtu}$ approved by PaDER.

As a consequence of the COA, Penelec completed a study comparing two regulatory air dispersion models to determine which is more appropriate for predicting ambient air concentrations in the Conewango Township and the surrounding region. One of the two models displayed more representative results compared with observed $\mathrm{SO}_{2}$ data and was selected for use in establishing $\mathrm{SO}_{2}$ emission limits for Warren Station. Based on the results from the selected model, Penelec proposed the following $\mathrm{SO}_{2}$ emission limits to PaDER: $3.47 \mathrm{lb} / \mathrm{MMBtu}$ during operation of a single unit and $3.32 \mathrm{lb} / \mathrm{MMBtu}$ during operation of both units. These limits will ensure attainment of the NAAQS for $\mathrm{SO}_{2} . \mathrm{PaDER}$ has 
verbally accepted the emission limits, and written approval is expected in the near future. A final provision of the COA states that Penelec must implement available control technology to reduce ozone formation from $\mathrm{NO}_{\mathrm{x}}$ and $\mathrm{VOC}$ emissions at Warren Station by May 31, 1995.

2. PaDER promulgated new ash disposal regulations which became effective July 4, 1992. Under the new regulations, Pennsylvania Residual Waste Management Regulations (PRWMRs), Penelec is required to either modify the currently permitted ash disposal facilities at Warren Station to conform to the PRWMRs, or close the facilities. The modifications include installation of synthetic liners and new groundwater monitoring systems at the active ash disposal area and ash ponds (GAI 1993b). Penelec installed the groundwater monitoring system in 1994 and has committed to installing liners at the active ash disposal area and ash ponds in 1996 and 1997, respectively. This compliance schedule was developed in consultation with PaDER (Gray 1994).

3. Power distribution studies in the Warren area indicated that the existing system is marginal during peak loads if Warren Station is not operating and one of two $115-\mathrm{kV}$ transmission lines in the area becomes inoperable. However, Penelec can use a $230-\mathrm{kV}$ transmission line that passes through Warren Station as a backup source of $115-\mathrm{kV}$ electricity if it adds a transformer to convert the electricity. Consequently, Penelec is constructing a new substation with a transformer to convert the $230-\mathrm{kV}$ line to $115 \mathrm{kV}$ in case of an event like that described above. The new substation will increase system reliability and integrity in the area.

\subsection{ALTERNATIVES TO THE PROPOSED ACTION}

The alternatives discussed in the following sections were considered through all three elements of the NEPA strategy presented in Sect. 1. The no-action altemative, altemative sites, and alternative technologies were considered during the project selection process and the project-specific preselection review. Brief summaries of the altematives are presented below. 


\subsubsection{No Action}

Under the no-action alternative, DOE would not provide cost-shared federal funding to demonstrate the EFCC technology proposed by Penelec. Without DOE participation, the Penelec project would be canceled, and the technology would probably not be demonstrated elsewhere because there are no other similar projects in the CCT Program. Consequently, commercialization of the EFCC technology could be delayed or might not occur because utility and industrial sectors tend to use known and demonstrated technologies over new, unproven technologies.

If the project were canceled, the new equipment would not be installed at Warren Station, and the facility would continue to operate without change. Thus, Warren Station would require the same amount of coal, water, and other materials that are currently used and would generate the same amount of air emissions, liquid discharges, and solid wastes (see Table 3.1). An exception is that $\mathrm{SO}_{2}$ emissions may increase slightly, contingent upon written approval by PaDER of the proposed $\mathrm{SO}_{2}$ emission limits (see Sect. 3.2). It is expected that both Units 1 and 2 would be retired in 5-10 years under this altemative. Table 3.4 presents a comparison of the potential environmental impacts of the proposed Penelec project with the no-action alternative. 
Table 3.4. Comparison of the potential environmental impacts for the proposed Penelec project versus the no-action alternative

\begin{tabular}{|c|c|c|}
\hline \multirow[b]{2}{*}{ Resource } & \multicolumn{2}{|c|}{ Environmental impact } \\
\hline & Proposed project & No action \\
\hline Atmospheric resources & $\begin{array}{l}\text { During construction, minimal air } \\
\text { quality impacts are expected from } \\
\text { disturbing about } 1 \text { acre. During } \\
\text { operation, a reduced impact on the air } \\
\text { quality of the area is expected. }\end{array}$ & $\begin{array}{l}\text { No change from existing } \\
\text { conditions. }\end{array}$ \\
\hline Surface water resources & $\begin{array}{l}\text { During construction, minimal } \\
\text { degradation to Allegheny River water } \\
\text { quality is expected. During operation, } \\
\text { water consumption is expected to } \\
\text { increase slightly; however, cooling } \\
\text { water and wastewater discharges } \\
\text { would not increase. Effects of thermal } \\
\text { discharge would not change. }\end{array}$ & $\begin{array}{l}\text { No change from existing } \\
\text { conditions. }\end{array}$ \\
\hline Groundwater resources & $\begin{array}{l}\text { The installation of liners at the on-site } \\
\text { ash disposal area and ash ponds } \\
\text { should prevent contaminants from } \\
\text { reaching the groundwater. }\end{array}$ & $\begin{array}{l}\text { The installation of liners at } \\
\text { the on-site ash disposal area } \\
\text { and ash ponds should } \\
\text { prevent contaminants from } \\
\text { reaching the groundwater. }\end{array}$ \\
\hline Floodplains & $\begin{array}{l}\text { The new building addition would be } \\
\text { built above the } 500 \text {-year floodplain. } \\
\text { No impacts are expected. }\end{array}$ & None. \\
\hline Wetlands & $\begin{array}{l}\text { The existing wetland would not be } \\
\text { disturbed. }\end{array}$ & None. \\
\hline Ecological resources, terrestrial & Negligible impacts are expected. & None. \\
\hline Ecological resources, aquatic & $\begin{array}{l}\text { Effects of the thermal plume would } \\
\text { not change. Intolerant and relatively } \\
\text { immobile fish or macroinvertebrates } \\
\text { entering the channel between Warren } \\
\text { Station and the small unnamed island } \\
\text { could be affected. }\end{array}$ & $\begin{array}{l}\text { No change from existing } \\
\text { conditions. Intolerant and } \\
\text { relatively immobile fish or } \\
\text { macroinvertebrates entering } \\
\text { the channel between } \\
\text { Warren Station and the } \\
\text { small unnamed island could } \\
\text { be affected. }\end{array}$ \\
\hline $\begin{array}{l}\text { Ecological resources, threatened and } \\
\text { endangered species }\end{array}$ & $\begin{array}{l}\text { A mussel survey found no threatened } \\
\text { or endangered mussel species in the } \\
\text { immediate vicinity. }\end{array}$ & $\begin{array}{l}\text { No change from existing } \\
\text { conditions. }\end{array}$ \\
\hline Land use & $\begin{array}{l}\text { No off-site land would be required. } \\
\text { No impacts are expected. }\end{array}$ & None. \\
\hline
\end{tabular}


Table 3.4 (continued)

\begin{tabular}{|c|c|c|}
\hline \multirow[b]{2}{*}{ Resource } & \multicolumn{2}{|c|}{ Environmental impact } \\
\hline & Proposed project & No action \\
\hline Waste management & $\begin{array}{l}\text { The quantity of fly ash and scrubber } \\
\text { waste would increase. Disposal would } \\
\text { still be accommodated on-site. }\end{array}$ & $\begin{array}{l}\text { No change from existing } \\
\text { conditions. }\end{array}$ \\
\hline Archaeological and cultural resources & $\begin{array}{l}\text { Implementation of recommendations } \\
\text { from a cultural resources survey } \\
\text { would minimize disturbance during } \\
\text { construction. }\end{array}$ & None. \\
\hline Socioeconomic resources & $\begin{array}{l}\text { Minor beneficial impacts are expected } \\
\text { in employment during construction. } \\
\text { No appreciable impacts are expected } \\
\text { during operation. }\end{array}$ & $\begin{array}{l}\text { No change from existing } \\
\text { conditions. }\end{array}$ \\
\hline Aesthetics & $\begin{array}{l}\text { The new building addition and raised } \\
\text { stack are expected to be aesthetically } \\
\text { compatible with the existing power } \\
\text { plant. Therefore, no appreciable } \\
\text { impacts to the essential visual } \\
\text { characteristics of the surrounding area } \\
\text { are expected. }\end{array}$ & $\begin{array}{l}\text { No change from existing } \\
\text { conditions. }\end{array}$ \\
\hline Noise & $\begin{array}{l}\text { Minor increases are expected during } \\
\text { construction. Minimal increases are } \\
\text { expected during operation. }\end{array}$ & $\begin{array}{l}\text { No change from existing } \\
\text { conditions. }\end{array}$ \\
\hline Electromagnetic fields (EMFs) & No impacts are expected. & $\begin{array}{l}\text { No change from existing } \\
\text { conditions. }\end{array}$ \\
\hline Human health and safety & $\begin{array}{l}\text { Impacts are not expected to be } \\
\text { appreciable. }\end{array}$ & $\begin{array}{l}\text { No change from existing } \\
\text { conditions. }\end{array}$ \\
\hline Environmental justice & $\begin{array}{l}\text { No systematic impacts to minority or } \\
\text { low-income groups are expected. }\end{array}$ & $\begin{array}{l}\text { No change from existing } \\
\text { conditions. }\end{array}$ \\
\hline
\end{tabular}




\subsubsection{Alternative Technologies and Sites}

Under CCT-V, DOE solicited proposals for cost-shared demonstration projects that would advance the efficiency and environmental performance of coal-using technologies and that would be applicable to either new or existing facilities. Factors applied in the selection process included the desirability of choosing projects that collectively (1) represent a diversity of methods, technical approaches, and applications; (2) use a broad range of U.S. coals; and (3) are in U.S. locations that represent a diversity of environmental health and safety standards, regulations, and climatic conditions. Otherwise, DOE did not constrain the proposals with regard to technology or site.

The proposals received a confidential preselection environmental review. This review summarized for the source selection official the strengths and weaknesses of each project relative to environmental evaluation criteria. To the maximum extent possible based upon the information provided in the proposal, the evaluation criteria included the following: (1) a discussion of altemative technologies and sites reasonably available, (2) a brief discussion of the potential environmental impacts, (3) necessary mitigative measures, and (4) a list of permits and licenses that would be required in implementing the proposal.

Based upon the technical and environmental merits of the proposals, the source selection official selected five projects, including the Penelec project, for possible cost-shared financial assistance under CCT-V. Given the nature of the CCT selection process, DOE is limited to either accepting or rejecting a selected demonstration project as proposed by the participant, 
including the proposed technology and site. Therefore, the only technology and site addressed in this EA are those proposed by Penelec. 


\section{EXISTING ENVIRONMENT}

This section profiles the environmental resources in the vicinity of the proposed Penelec project. The resources discussed include relevant physical, biological, social, and economic conditions that might be altered through the implementation of the proposed action or alternatives to the proposed action.

\subsection{ATMOSPHERIC RESOURCES}

The climate and air quality of the area are discussed below.

\subsubsection{Climate}

The Warren area has a continental climate, with cool winters, warm and humid summers, and mild fall and spring seasons. In winter, daily high temperatures average about $37^{\circ} \mathrm{F}$, and daily low temperatures average just under $20^{\circ} \mathrm{F}$. Typical summer maximum and minimum temperatures are about $80^{\circ} \mathrm{F}$ and $55^{\circ} \mathrm{F}$, respectively. Annual precipitation is about 43 in./year (Gale Research 1985).

The prevailing winds (including strongest winds) at Warren Station are from the west. Figure 4.1 displays a wind rose ${ }^{1}$ for winds recorded at Warren Station at a height of $410 \mathrm{ft}$. These winds are measured at a meteorological tower located about $450 \mathrm{ft}$ to the east-northeast of the Warren Station stack.

\footnotetext{
'A wind rose is a graph plotting the frequency of wind blowing from each direction as a bar that extends from the center of the diagram. Wind speeds are denoted by bar widths and shading; the frequency of the wind speeds within each direction is depicted according to the length of that section of the bar. Note that the wind rose displays directions from which the wind originates; emissions would travel downwind in the opposite direction.
} 


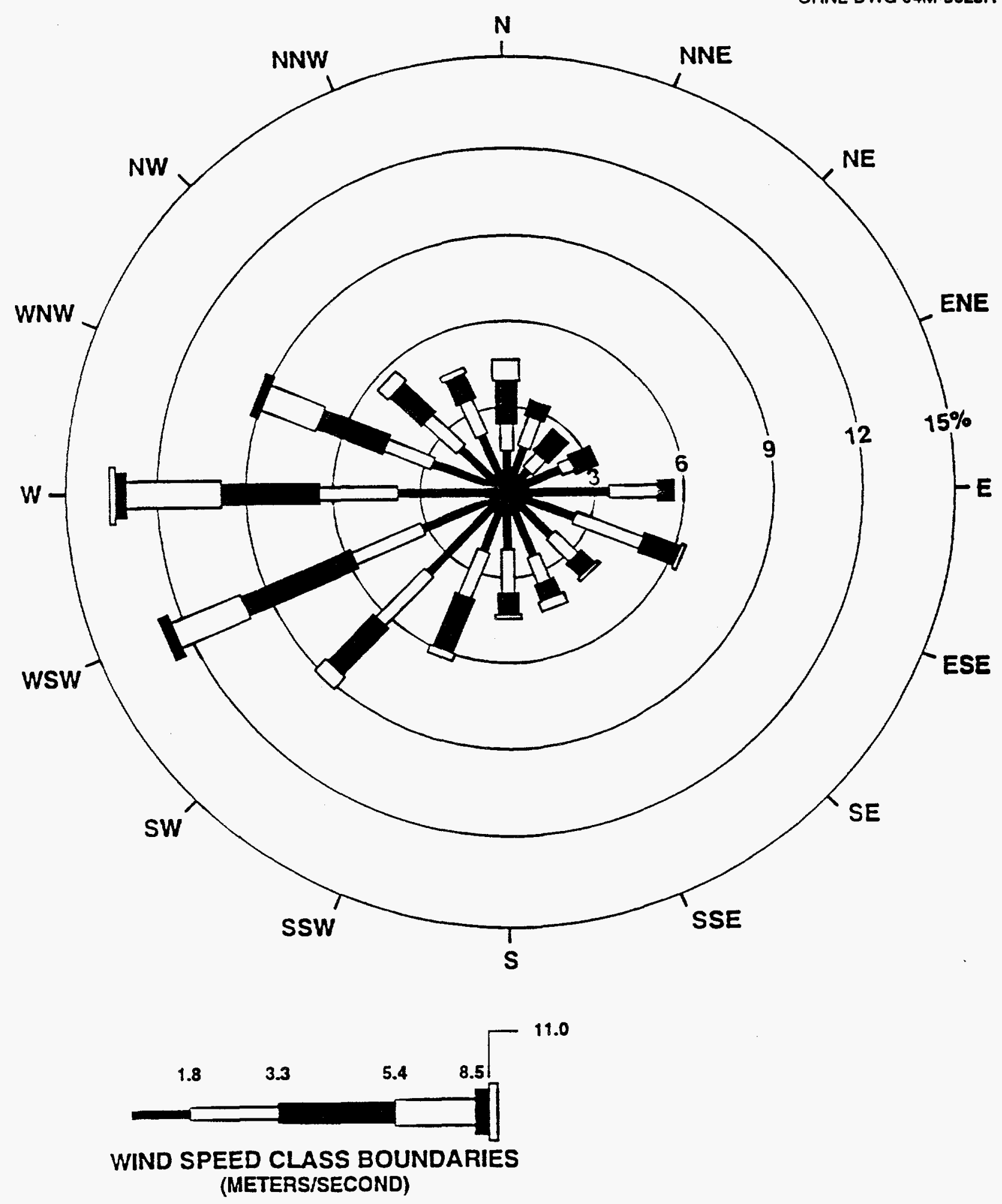

Fig. 4.1. Wind rose for Warren Station recorded at a height of $410 \mathrm{ft}$. 


\subsection{Air Quality}

NAAQS exist for the following criteria pollutants: particulate matter less than $10 \mu \mathrm{m}$ in diameter (PM-10, the inhalable particulate matter), $\mathrm{SO}_{2}$, nitrogen dioxide $\left(\mathrm{NO}_{2}\right), \mathrm{CO}$, ozone, and lead. Pennsylvania has adopted NAAQS as the state standards (Table 4.1). Conewango Township is classified as being in nonattainment for $\mathrm{SO}_{2}$ because of local emissions and those transported up the Allegheny River Valley by prevailing winds from the west. The nonattainment designation dates back to 1977 and was originally based on predicted concentrations using air dispersion models approved by the EPA. However, an ambient air monitor operated by PaDER, located in the city of Warren, recorded two exceedances of the 3-h ambient $\mathrm{SO}_{2}$ standard in October 1993. These exceedances were attributed to high emissions associated with two nonrelated malfunctions of the desulfurization process at the United Refinery in Warren [Larry Wonders, Pennsylvania State Bureau of Air Quality Control, Meadville Region, Meadville, Pennsylvania, personal communication with D. A. Lombardi, Oak Ridge National Laboratory (ORNL), Oak Ridge, Tennessee, November 23, 1993]. Until these episodes, this monitor had not recorded any exceedances of the annual, 24-h, or 3-h ambient $\mathrm{SO}_{2}$ standards (ASC 1993). Conewango Township is in attainment for all other criteria pollutants. The city of Warren monitor measures only ambient $\mathrm{SO}_{2}$ concentrations. The nearest monitor that records ambient concentrations of criteria pollutants other than $\mathrm{SO}_{2}$ is located near Erie, Pennsylvania, about 50 miles west-northwest of Warren Station. All criteria pollutants are monitored at this location. Ambient air quality monitoring data are summarized in Table 4.1. 
Table 4.1. Ambient air quality monitoring data for Warren and Erie, Pennsylvania

\begin{tabular}{|c|c|c|c|c|}
\hline Pollutant ${ }^{a}$ & $\begin{array}{l}\text { Averaging } \\
\text { time }\end{array}$ & $\begin{array}{c}\text { NAAQS }^{a} \\
\left(\mu \mathrm{g} / \mathrm{m}^{3}\right)\end{array}$ & $\begin{array}{l}\text { Concentration } \\
\left(\mu \mathrm{g} / \mathrm{m}^{3}\right)\end{array}$ & $\begin{array}{l}\text { Percent of } \\
\text { standard }\end{array}$ \\
\hline \multicolumn{5}{|c|}{ City of Warren monitor } \\
\hline \multirow[t]{3}{*}{$\mathrm{SO}_{2}$} & 3-h & 1300 & $755^{b}$ & 58 \\
\hline & 24-h & 365 & $257^{b}$ & 70 \\
\hline & annual & 80 & $37^{r}$ & 46 \\
\hline \multicolumn{5}{|c|}{ City of Erie monitor } \\
\hline \multirow[t]{3}{*}{$\mathrm{SO}_{2}$} & $3-h$ & 1300 & $401^{d}$ & 31 \\
\hline & 24-h & 365 & $272^{d}$ & 75 \\
\hline & annual & 80 & $29^{\circ}$ & 36 \\
\hline $\mathrm{NO}_{2}$ & annual & 100 & $26^{e}$ & 26 \\
\hline \multirow[t]{2}{*}{ PM-10 } & 24-h & 150 & $57^{d}$ & 38 \\
\hline & annual & 50 & $22^{e}$ & 44 \\
\hline Ozone & $1-\mathrm{h}$ & 235 & $216^{d}$ & 92 \\
\hline \multirow[t]{2}{*}{$\mathrm{CO}$} & $1-\mathrm{h}$ & 40,000 & $8970^{d}$ & 22 \\
\hline & $8-\mathrm{h}$ & 10,000 & $4600^{d}$ & 46 \\
\hline Lead & Calendar quarter & 1.5 & $0.05^{d}$ & 3 \\
\hline
\end{tabular}

Source: PaDER (Pennsylvania Department of Environmental Resources) 1993a. Pennsylvania Air Quality Report, DER 407-6/93, Commonwealth of Pennsylvania, Harrisburg.

"NAAQS = National Ambient Air Quality Standards; $\mathrm{SO}_{2}=$ sulfur dioxide; $\mathrm{NO}_{2}=$ nitrogen dioxide; $\mathrm{PM}-10=$ inhalable particulate matter with aerodynamic diameter of $10 \mu \mathrm{m}$ or less; $\mathrm{CO}=$ carbon monoxide.

${ }^{b}$ Maximum measured concentration between 1988 and 1992.

'Maximum average annual concentration between 1988 and 1992.

"Maximum measured concentration in 1992.

'Average annual concentration measured in 1992. 
The CAAA includes a new provision that no federal agency shall support any activity that does not conform to a SIP designed to achieve NAAQS. On November 30, 1993, the EPA issued a final rule implementing the new statutory requirements for this provision (58 FR 63214), effective as of January 31,1994 . The final rule requires that federal agencies prepare a written conformity analysis and determination for proposed actions in nonattainment areas for which the total of direct and indirect emissions of criteria pollutants caused by the action would exceed the threshold emission levels shown at 40 CFR Part 51.853(b).

DOE has examined the applicability of the conformity rule for the proposed project. In spite of the increase in capacity and expected increase in operating time for Unit 2, annual $\mathrm{SO}_{2}$ emissions at Warren Station are expected to decrease by about $40 \%$, from approximately 8000 tons to 4800 tons, as $\mathrm{SO}_{2}$ emissions at Unit 2 decrease from about 4000 tons to 800 tons. Thus the net change in direct and indirect $\mathrm{SO}_{2}$ emissions caused by the action would be negative (a decrease in emissions), which would be less than the conformity rule's $\mathrm{SO}_{2}$ threshold emission level of 100 tons/year. Therefore, DOE believes the proposed project would be exempt from the conformity rule. DOE has conferred with EPA and PaDER staff, who have concurred with DOE's determination (Gerry Pomerantz, EPA, Research Triangle Park, North Carolina, personal communication with Jan Wachter, DOE, September 21, 1994, and John Slade, Pennsylvania State Bureau of Air Quality Control, Harrisburg, Pennsylvania, personal communication with Wennona Brown, DOE, February 13, 1995).

Dolly Sodds Wilderness Area, 200 miles south of Warren Station, is the nearest prevention of significant deterioration (PSD) Class I area. PSD Class I areas are designated to greatly restrict the degradation of ambient air quality. Less stringent PSD requirements exist 
for Class II areas, which currently include all areas of the United States that are not designated Class I (including the nearby Allegheny National Forest).

\subsection{WATER RESOURCES}

The surface water and groundwater resources in the vicinity of Warren Station are discussed in this section.

\subsubsection{Surface Water Resources}

Warren Station is located on a glaciofluvial floodplain near Allegheny River mile (ARM) 186 between Starbrick and Warren, Pennsylvania (USGS 1981). The power plant is situated on a $20-30-\mathrm{ft}$ sand and gravel terrace that rises abruptly from the water surface. Ten storage reservoirs on the Allegheny River provide flood control, low-flow augmentation, and dilution for water quality maintenance (COE 1975; McCarren 1967). Conewango Creek joins the Allegheny River approximately 3 miles upstream from Warren Station at Warren (near ARM 189) (USGS 1981; COE 1975). Minimal storage is available in the Conewango Creek watershed for flood control.

Kinzua Dam, which became operable in 1967, forms Allegheny Reservoir approximately 12 miles upstream from Warren Station near ARM 198. The powerhouse at the base of the dam generates electricity, and the 12,000-acre reservoir provides pumped storage. Kinzua Dam maintains a minimum Allegheny River flow of $500 \mathrm{ft}^{3} / \mathrm{s}(224,000 \mathrm{gpm})(\mathrm{COE} 1975)$. The annual average discharge near ARM 189 below the confluence with Conewango Creek was 
$6836 \mathrm{ft}^{3} / \mathrm{s}(3,068,000 \mathrm{gpm})$ for 1989-1991 (adjusted for change in contents of Allegheny Reservoir) (Lescinsky et al. 1992). The flow exceeded $1580 \mathrm{ft}^{3} / \mathrm{s}(709,000 \mathrm{gpm}) 90 \%$ of the time. The 10-year, 7-day low flow of the Allegheny River is $579 \mathrm{ft}^{3} / \mathrm{s}(260,000 \mathrm{gpm}$ ) (ASC 1993).

The Allegheny River near Warren Station is not regulated by the Allegheny Wild and Scenic River Act (ASC 1993). This exempted (unregulated) segment of the river begins slightly over 1 mile upstream of Warren Station at the U.S. Highway 6 bridge in Warren and extends downstream about 6 miles past Warren Station to the Buckaloons Recreational Area. Islands, riffles, sandbars, and shoals are present along the upper Allegheny River floodplain. The main channel passes between Warren Station and the adjacent Mead Island to the south (see Fig. 3.1). The main channel is too shallow for commercial transportation, water skiing, or speedboating (ASC 1993). Recreational sports such as fishing, canoeing, and swimming predominate.

A shallow channel has been excavated to convey warmed water discharged from the condensers into the Allegheny River. A small island (see Fig. 3.2), distinct from Mead Island, exists at the end of the discharge channel and splits the discharge. Downstream of the discharge, the main river channel has been dredged for gravel by a sand and gravel company to a depth of 10-30 ft along most of the length of Mead Island.

The Warren Station local drainage system consists of a series of man-made ditches and culverts that divert stormwater into the Allegheny River, either directly or by way of the ash ponds. Construction of Warren Station changed most of the site's natural drainage. A small, unnamed, north-to-south running creek with low perennial flow trickles into the river between the ash ponds (see Fig. 3.2). 
Surface water withdrawals range from 77 to $310 \mathrm{ft}^{3} / \mathrm{s}(35,000$ to $139,000 \mathrm{gpm})$ in Warren County (Wetzel, Johnson, and Gast 1990). Approximately $70 \%$ of this withdrawal serves as cooling water for thermoelectric power generation, including water for Warren Station. Almost all thermoelectric cooling water is returned to the river. Industry and mining account for $20 \%$, while public and municipal water supplies use the remaining $10 \%$. The PAWC draws water from the Allegheny River upstream of Warren Station in Warren. The nearest downstream municipal water supply is located more than 50 miles away in the town of Emlenton, Pennsylvania.

\subsubsection{Groundwater Resources}

Warren Station is located in a region characterized as an unglaciated, maturely dissected plateau with gently rolling uplands, deep narrow valleys, and steeply rising slopes (COE 1975). The estimated normal level of the river near Warren Station is $1162 \mathrm{ft}$ above mean sea level (MSL) (GAI 1993b). The power station is located on a river terrace with elevations varying from $1170 \mathrm{ft}$ MSL near the river bank to $1194 \mathrm{ft} \mathrm{MSL}$ at the northern property line (ASC 1993). The terrace is composed of glacial outwash sediments of sand and gravel and a

3- to 5-ft top layer of more recent alluvial deposits of silt and clay. North of U.S. Highway $6 / 62$, the terrace ends at the rising bedrock wall of the hillside.

The two groundwater resources in the Warren Station area are the outwash deposits aquifer and the underlying bedrock aquifer. The top of the bedrock formation lies about 60 to $100 \mathrm{ft}$ beneath the ground. The general direction of groundwater flow in the Warren Station area is from the valley wall and surrounding uplands toward the Allegheny River to the south. 
The outwash deposits aquifer has greater potential for groundwater development than the bedrock aquifer. Some of the larger towns, such as Warren, tap the outwash deposits aquifer for their public and industrial water supplies (Deutsch et al. 1969). Yields from 100 to $2000 \mathrm{gpm}$ are common from these deposits because they are very permeable and receive recharge from the Allegheny River. PAWC, located about 1 mile upstream of Warren Station, supplies potable water from the outwash deposits aquifer to Warren Station (about $4 \mathrm{gpm}$ ) and the surrounding area (T. R. Peterson, Operations Manager, PAWC, Warren, Pennsylvania, personal communication with J. C. Wang, ORNL, Oak Ridge, Tennessee, November 16, 1993). Warren Station does not withdraw groundwater directly.

Figure 4.2 indicates the location of monitoring wells at Warren Station. The chemical characteristics of water from wells drilled into the outwash deposits aquifer (MW-5, MW-6, MW-7, MW-9, and MW-10) are compared in Table 4.2 with the general characteristics of the outwash deposits aquifer in the Allegheny River valley (Deutsch et al. 1969). Similarly, the chemical characteristics of water from well MW-4 drilled into the underlying bedrock aquifer are compared in Table 4.2 with the general characteristics of the bedrock aquifer in the Allegheny River valley (Deutsch et al. 1969).

\subsubsection{Floodplains and Wetlands}

The proposed project would be constructed north of the main generator building at elevation $1190 \mathrm{ft}$ MSL. Floodplain maps issued by the Federal Emergency Management Agency indicate that the construction area is outside the 500-year floodplain (ASC 1993). Kinzua Dam has mitigated flooding from storms that occur within its watershed. Since the 
ORNL.DWG94-7666

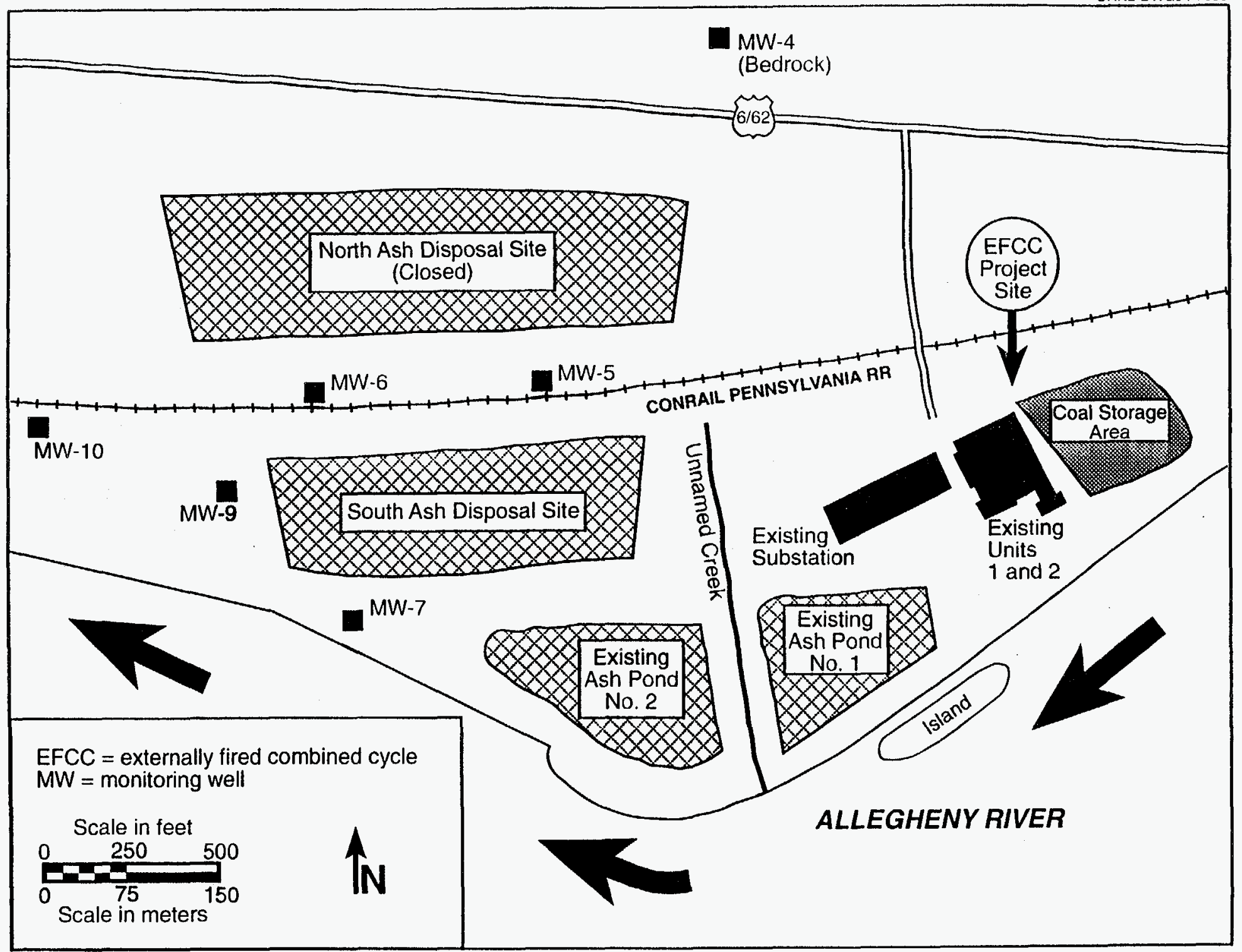

Fig. 4.2. The location of the monitoring wells (MWs) at Warren Station. 
Table 4.2. Chemical characteristics of the outwash deposits aquifer and bedrock aquifer at Warren Station and in the Allegheny River valley in general

\begin{tabular}{|c|c|c|c|c|}
\hline \multirow[b]{2}{*}{ Parameter } & \multicolumn{2}{|c|}{ Outwash deposits aquifer } & \multicolumn{2}{|c|}{ Bedrock aquifer } \\
\hline & $\begin{array}{l}\text { Warren } \\
\text { Station }\end{array}$ & $\begin{array}{c}\text { Allegheny River } \\
\text { valley in general }{ }^{b}\end{array}$ & $\begin{array}{l}\text { Warren } \\
\text { Station }^{\alpha}\end{array}$ & $\begin{array}{l}\text { Allegheny River } \\
\text { vailey in general }\end{array}$ \\
\hline $\mathrm{Ca}^{++}(\mathrm{mg} / \mathrm{L})^{c}$ & $34.7-407$ & - & 53.5 & - \\
\hline Hardness (mg/L) & 一 & $120-280$ & - & $50-190$ \\
\hline Sulfate $(\mathrm{mg} / \mathrm{L})$ & $77.3-972$ & $15-350$ & 25.7 & $1-25$ \\
\hline Chloride (mg/L) & $3.53-55.6$ & $30-90$ & 19.3 & $2-71$ \\
\hline Dissolved iron $(\mathrm{mg} / \mathrm{L})$ & $0.02-54.4$ & $0-3.0$ & 1.51 & $0.04-1.5$ \\
\hline $\begin{array}{l}\text { Total dissolved solids } \\
(\mathrm{mg} / \mathrm{L})\end{array}$ & - & $180-600$ & 一 & $140-320$ \\
\hline $\mathrm{pH}$ & $5.88-7.37$ & - & 7.15 & - \\
\hline
\end{tabular}

${ }^{\circ} \mathrm{GAI} 1993 \mathrm{a}$.

'Deutsch et al. 1969.

Divalent calcium cation.

completion of Kinzua Dam in 1967, the worst flood occurred during Hurricane Agnes in June 1972, during which flooding at Warren Station was minor. During extreme storms, occasional flooding also has occurred in low-lying areas of Warren near the confluence of Conewango Creek and the Allegheny River.

The Warren Station site has one federally designated wetland, which is $3-4$ acres in size and is located along the Allegheny River next to the ash ponds, about $1000 \mathrm{ft}$ west to southwest of the plant buildings (see Fig. 3.2). The National Wetlands Inventory classifies this wetland as a palustrine wetland that has open water/unknown bottom and is intermittently exposed/permanent. This type of wetland is a pond that dries up during extended dry weather and is dominated by open water with relatively little emergent vegetation such as cattails, rushes, shrubs, or trees (Cowardin et al. 1979). 


\subsection{ECOLOGICAL RESOURCES}

The ecological resources in the vicinity of Warren Station are discussed in this section.

\subsubsection{Terrestrial Ecology}

Power plant construction, operation, and support activities have disturbed almost all of the Warren Station site. Vacant areas generally have lawns, weedy or herbaceous vegetation, and some small stands or strips of young trees. Reclaimed ash disposal areas have a cover of herbaceous vegetation. A narrow strip of undisturbed, mature riparian woods is present on the river bank along the site boundary, and a small stand of undisturbed mature trees is located on the eastern end of the site. Also, a narrow strip of young trees and brush is located just west of the plant buildings on the banks of the small unnamed stream that flows south through the Warren Station site into the Allegheny River. Vegetation on the proposed site consists of lawn and several planted shrubs. Because natural undisturbed habitats are lacking on the Warren Station site, relatively few wildlife species occur there, and their population densities are relatively low. Thus, the site does not support any particularly important biotic resource.

The principal forest type in the Warren area is Allegheny hardwood or maplebeech-birch (Eyre 1980). Major tree species include red maple, sugar maple, beech, yellow birch, black cherry, white ash, and eastern hemlock. Wildlife is abundant in the region and includes white-tailed deer, black bear, eastem cottontail, wild turkey, ruffed grouse, red and gray foxes, red-tailed hawk, great homed owl, and many other species (U.S. Forest Service 1991). 


\subsubsection{Aquatic Ecology}

In the early 1970 s, extensive sampling of the upper Allegheny River by the Pennsylvania Fish Commission identified 70 species of fish (Table A.1, Appendix A) and 58 taxa of macroinvertebrates between Kinzua Dam (about 12 miles upstream of Warren Station) and a station near the town of Franklin (about 50 miles downstream of Warren Station). Warmwater game fish found in the study area include smallmouth bass, largemouth bass, walleye, muskellunge, and to a lesser extent northem pike. The upper Allegheny River, including the reach from Allegheny Reservoir downstream to Franklin, provides a major, selfsustaining, high-quality recreational sport fishery (Lee 1975; FERC 1988). As a result of the hypolimnetic (cold-water) release from Kinzua Dam, the flume of released water provides a fishery for both brown and rainbow trout. According to Ron Lee, Pennsylvania Fish Commission (personal communication with V. R. Tolbert, ORNL, Oak Ridge, Tennessee, November 8, 1993), there have been no appreciable changes in the density and composition of fish species in the vicinity of Warren since the 1970 s biological study.

The 58 taxa of macroinvertebrates collected between Kinzua Dam and Franklin in the early 1970 s included crayfish, isopods, a variety of insect genera, snails, and clams. Lee (1975) reported a reduced density of macroinvertebrates between Kinzua Dam and Warren, which was attributed to substrate disturbance resulting from construction of the dam rather than to lack of food sources to support these species.

Conewango Creek is important to the overall productivity of the upper Allegheny River because it provides unregulated flow into the river and constitutes approximately one-third of the river flow in the Warren Station vicinity (see Sect. 4.2.1). Because of the swamp areas 
associated with the creek, it is highly productive and can provide additional, good quality habitat for fish and benthic (bottom-dwelling) species. The predominant fish species found in Conewango Creek by Lee (1975) were carp and suckers, with smaller populations of largemouth and smallmouth bass, walleye, muskellunge, bullhead, and northem pike (Lee 1975; McCarren 1967).

\subsubsection{Threatened and Endangered Species}

In response to requests for information on threatened and endangered species, correspondence was received from the U.S. Fish and Wildlife Service (Kulp 1994), the Pennsylvania Game Commission (McDowell 1994), and PaDER (Dix 1994). No plant species listed, or proposed for listing, by the U.S. Fish and Wildlife Service as threatened or endangered is known to occur in the vicinity of Warren Station. The only listed terrestrial animal species known to occur occasionally in the vicinity of Warren Station is the endangered bald eagle, which may be found along the river during the winter. No eagle nest is known to be present in the region.

The Allegheny River near Warren Station is within the known range of two federally listed endangered mussels: the northern riffleshell mussel and the clubshell mussel. The closest reported location of the northem riffleshell mussel to Warren Station is approximately 7 miles downstream of the station (Kulp 1994). The closest reported location of the clubshell mussel to Warren Station is 30 miles downstream of the station, near the town of Tionesta (ASC 1993). The longhead darter, a candidate species for federal protection, has been found near Leek Island, about 2 miles downstream of the station, according to the Pennsylvania 
Conservancy (1989, cited in ASC 1993). Downstream of Kinzua Dam, the cold water discharge from the dam has affected the occurrence of the northern riffleshell mussel and the reproduction of the longhead darter (ASC 1993). Nevertheless, both species of mussels and the longhead darter could occur in the vicinity of Warren Station if this stretch of the Allegheny River contains suitable habitat and adequate water quality (Kulp 1994).

The Ohio lamprey, a Pennsylvania threatened species, was reported approximately 5 miles downstream of Warren Station during a survey conducted in 1985 by Pennsylvania State University (Shiels 1994). The same survey found the Pennsylvania endangered tippecanoe darter and the Pennsylvania threatened bluebreast darter and channel darter 5 miles downstream. The bluebreast darter was also found at a location near Starbrick, Pennsylvania, about 1 mile downstream from Warren Station. Any of these species may be present in the vicinity of Warren Station.

A mussel survey conducted in September 1994 as part of this EA did not find either of the two endangered mussel species present in the vicinity of Warren Station (Bogan 1994) (see Sect. 5.1.3.3). As recommended by the U.S. Fish and Wildlife Service (Carole Copeyon, U.S. Fish and Wildlife Service, State College, Pennsylvania, personal communication with R. L. Miller, ORNL, Oak Ridge, Tennessee, May 17, 1994), a survey was not conducted for the Ohio lamprey or the darters because these species are more mobile and would be able to avoid any potential areas of adverse impact. 


\subsubsection{Biodiversity}

Biodiversity is a measure of the variety or richness of our natural biotic environment (i.e., the numbers of habitat types and species provide a measure of variety). The proposed site and adjacent area that would be affected by project construction have no natural vegetation or habitat because they consist of lawn, planted shrub, and disturbed weedy areas. Therefore, there is negligible biodiversity in the area that would be affected by the proposed project. High biodiversity is present on a regional scale in the large variety of terrestrial and aquatic environments surrounding the Warren Station site. For example, many fish species are present in the Allegheny River, and many terrestrial habitat types and hundreds of animal species are present within 20 miles of Warren Station.

\subsection{LAND USE}

The 1-acre site for the proposed project (the amount of area to be physically occupied by the building addition) is part of the 96 -acre Warren Station site, which is zoned for industrial use by Warren County (ASC 1993). The site layout drawing shown in Fig. 3.2 indicates current land uses on the Warren Station site. About half of the site ( 40 acres) is dedicated to ash disposal, including the completely filled and closed North Ash Disposal Site and the active South Ash Disposal Site. The two ash ponds, substation, plant building, coal pile, and permanent archaeological research site occupy most of the remainder of the site. The proposed project site includes a maintained lawn, a plant road, and the southeast comer of the 
scale house for weighing coal trucks. The entire proposed site was previously disturbed during construction of the existing power station.

The Warren County Comprehensive Plan map shows that existing land use on the Warren Station site is industrial and land use adjacent to the site is predominantly commercial, with a few residences. Existing land use within 3 miles of the Warren Station site is roughly $70 \%$ forest, $15 \%$ commercial or residential, $10 \%$ agricultural, and $5 \%$ miscellaneous (ASC 1993). The Allegheny National Forest occupies most of the area south of the site across the Allegheny River.

No prime farmland is located on the Warren Station site. The Farmland Protection Policy Act of 1981 (7 U.S.C. 4201 et seq.) states that the designation "prime farmland" does not include land already (i.e., before 1981) in or committed to urban development. The Warren Station site has been committed to urban development since the plant started operation in 1948.

\subsection{ARCHAEOLOGICAL AND CULTURAL RESOURCES}

Archaeological investigations have identified significant prehistoric, protohistoric, and historic occupations on the Warren Station site (Carnegie Museum and Pennsylvania Bureau for Historic Preservation Site 36 Wa 152). There has been an ongoing investigation at this site; the study site is fenced and located $825 \mathrm{ft}$ east of the proposed project site near the station's eastem boundary. The area planned for construction of the proposed project has previously been disturbed (ASC 1993). Section 5.1.6 discusses the results of two cultural resources surveys of the Warren Station site. 


\subsection{SOCIOECONOMIC RESOURCES}

Warren County had a population of 45,050 in 1990 , down $5.1 \%$ from the 1980 population. The city of Warren had a population of 11,162 in 1990 , down $8.1 \%$ from 1980 . The declining population reflects, to some extent, the general trend of declines in industrial and mining employment in westem Pennsylvania. Warren County's population is $99.4 \%$ Caucasian.

Total employment in Warren County was about 21,600 in 1990 (Regional Economic Information System, Bureau of Economic Analysis, April 1992). In 1992, unemployment in Warren County averaged $7.4 \%$, which was essentially the same as the rate for Pennsylvania and the United States (Pennsylvania Department of Labor and Industry, Department of Statistics, personal communication with J. W. Van Dyke, ORNL, Oak Ridge, Tennessee, November 3,1993 ). In 1990 , per capita income for Warren County was $88 \%$ of the average per capita income in Pennsylvania and $86 \%$ of the per capita income in the United States. However, only $9.5 \%$ of Warren County households were below the poverty line, compared with $11.4 \%$ for Pennsylvania and $13.1 \%$ for the United States.

The housing vacancy rate for Warren County was $22.5 \%$, compared with Pennsylvania's rate of $6.9 \%$. The high vacancy rate partially reflects the declining population. The median home value was $\$ 43,943$, compared with $\$ 69,689$ for Pennsylvania.

Vehicle access to the proposed project would be via U.S. Highway 6/62, a divided highway with two lanes in each direction which runs just north of the Warren Station site. The latest average daily traffic count for U.S. Highway $6 / 62$, taken in 1992 , was 13,420 (total for both directions) for the road segment along Warren Station (Bill Swartzfager, Pennsylvania 
Department of Transportation, Traffic Unit for District 10, personal communication with J. W. Van Dyke, ORNL, Oak Ridge, Tennessee, November 17, 1993). Traffic along this road is not congested during normal rush hours. Around 3:30 P.M. there can be delays of 2 to 3 min at the "jughandles" (turnoff points along the highway that provide for crossing the median and going in the opposite direction) due to increased traffic from the National Forge and Blair plants, both about 4 miles west of Warren Station (Jim Ostergard, Permit Inspector for Warren and Forest Counties, Pennsylvania Department of Transportation, personal communication with J. W. Van Dyke, ORNL, Oak Ridge, Tennessee, November 16, 1993).

Coal is transported to the plant by truck from a distance of approximately 50-85 miles from Clearfield, Elk, Jefferson, and Clarion counties. Delivery routes include Highways 6, 36, 59, and 219. No coal trucks are routed through downtown Warren (ASC 1993). Although the Allegheny Railroad track skirts the Warren Station site, the power plant does not use the railroad's services because it does not have the infrastructure in place to unload coal transported by train. The Allegheny River is not used for commercial transportation.

Potable water is supplied by PAWC. Warren Station has on-site sewage disposal, including septic tanks and a leach field. Sanitary waste is disposed of at local landfills. The Starbrick volunteer fire department, about 1 mile west of Warren Station, provides fire protection. Police protection is through the Conewango Township Police Department, located about 1 mile west of Warren Station. The proposed site is within the Warren District County School System. 


\subsection{AESTHETICS}

Warren Station is clearly visible from U.S. Highway $6 / 62$ and has the most prominent structures in the area, including the facility's generation building, coal storage area, and substation. Other facilities associated with Warren Station that are visible from the highway include a closed ash disposal area and a fuel oil tank. Many of Warren Station's facilities are also visible from the Allegheny River, which is used for recreational water activities. In general, Warren Station, built in 1948, is a long-time fixture within a rural/commercial setting.

\subsection{NOISE}

Sensitive noise receptors near Warren Station include sparsely situated residences (approximately $1200-3000 \mathrm{ft}$ from the generation building at Warren Station in various directions, particularly to the west and southeast); a hotel $1000 \mathrm{ft}$ to the north; a hospital about 2 miles to the east; a school about 1 mile to the west; and a nursing home about 1 mile to the east-southeast. Major sources of noise in the area include traffic along U.S. Highway $6 / 62$ and industrial noise from a quarry located about $3000 \mathrm{ft}$ west of the facility on the north shore of the Allegheny River and on Mead Island. The existing Warren Station also contributes to the background noise levels in the area. While most noise-generating equipment at Warren Station is located indoors, mobile equipment operates during the daytime in the area of the coal pile and the ash disposal area. This equipment is generally not audible off-site except for the backup alarms on the equipment. During periods of minimal background sound levels, such as 
at night, the switchyard transformer hum and some airflow sound from the exhaust duct, precipitators, and stack are audible at nearby residences.

A noise survey conducted in October 1993 measured ambient sound levels at four locations that represent the site boundary and nearby residences (Fig. 4.3) (Black and Veatch 1993). Measurements were taken at 1-h averaging times over 3 days at each location.

Table 4.3 presents the ranges of equivalent sound levels $\left(\mathrm{L}_{\mathrm{eq}}\right.$, the energy-averaged sound level integrated over the measurement period) and background noise levels ( $\mathrm{L}_{90}$, the noise level exceeded for $90 \%$ of the averaging time) for each location. The measured background levels are in the range of about 40 to $60 \mathrm{~dB}(\mathrm{~A}){ }^{2}$ These levels, which characterize a relatively quiet environment, are similar to those at an average residence or of conversational speech at a distance of $3 \mathrm{ft}$. The $43 \mathrm{~dB}(\mathrm{~A})$ background level at location 1 was measured during the night and reflects the sound level attributable to the steady operation of the existing Warren Station equipment.

Table 4.3. Ambient noise measurements ${ }^{2}[\mathrm{~dB}(\mathrm{~A})]$

\begin{tabular}{lcc}
\hline \multicolumn{1}{c}{ Noise measurement location } & Range of 1-h $\mathrm{L}_{\mathrm{eq}}$ Range of 1-h $\mathrm{L}_{90}$ \\
\hline $\begin{array}{l}\text { 1. Northern plant boundary } \\
\text { 2. Nearest residences to the north (across U.S. }\end{array}$ & $54-70$ & $43-62.5$ \\
Highway 6/62) & $50-61.5$ & $43-56$ \\
3. Nearest residences to the west (western boundary) & $41-61$ & $40-55$ \\
4. Nearest residences to the south (across the river) & $42.5-55$ & $41-47$ \\
\hline
\end{tabular}

Source: Adapted from Black and Veatch (1993).

'Includes some rainy periods that can cause increased noise; excludes erroneous or justifiably rejected points; measurements were taken over a 3-day period. levels.

${ }^{2}$ Decibels using the A-weighted scale; best simulates the frequency response of the human ear to audible sound 


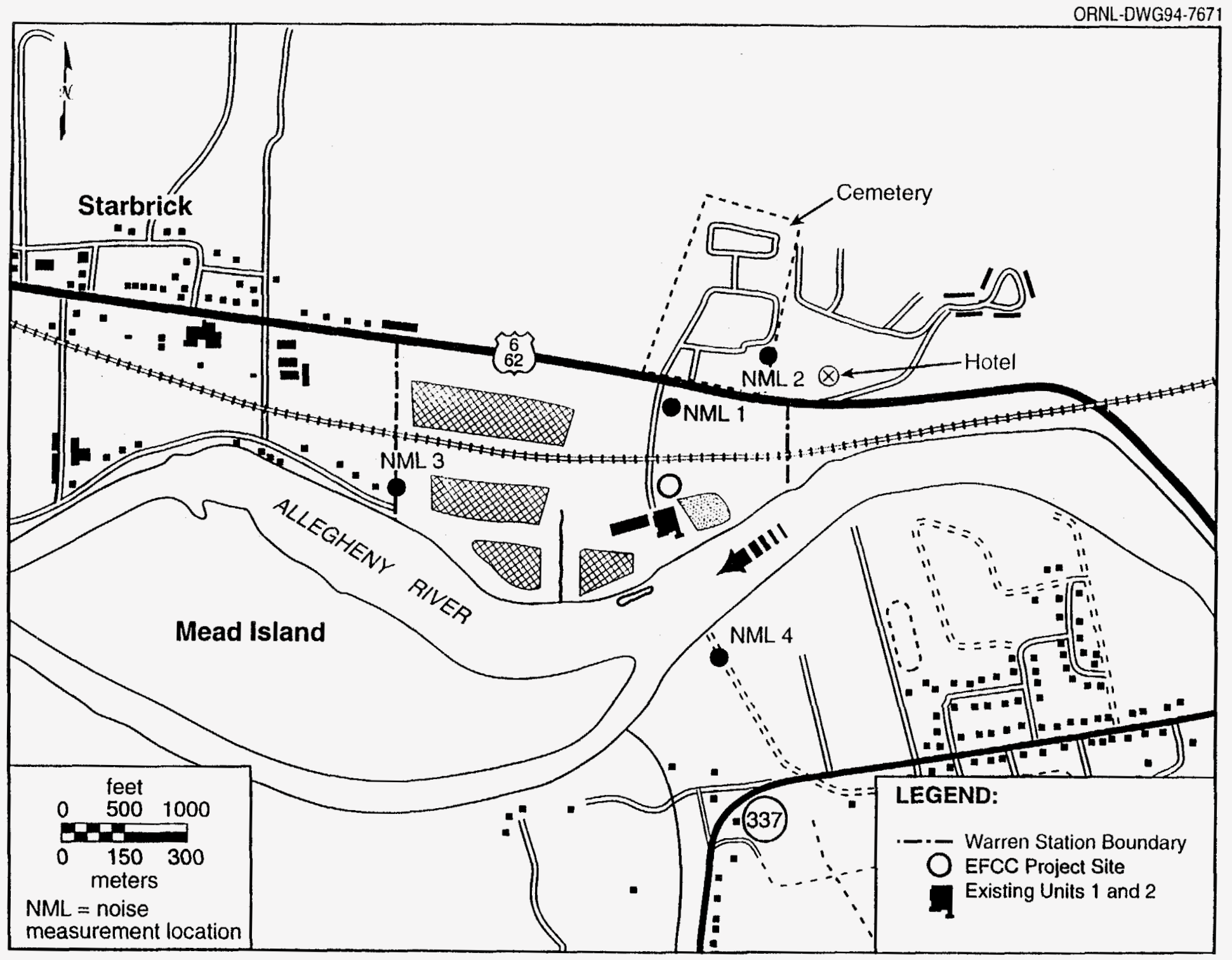

Fig. 4.3. Ambient noise measurement locations near Warren Station. 


\section{ENVIRONMENTAL CONSEQUENCES}

This section analyzes the potential impacts to human and environmental resources resulting from the proposed action and no action. Also included are discussions of the environmental impacts of commercial operations following the demonstration, cumulative environmental impacts, and pollution prevention measures.

\subsection{ENVIRONMENTAL IMPACTS OF THE PROPOSED ACTION}

This section evaluates the potential impacts resulting from construction and operation of the proposed Penelec project during the demonstration.

\subsubsection{Atmospheric Resources}

Potential effects on atmospheric resources are discussed, including changes in ambient air quality and global climate change.

\subsubsection{Construction}

Air quality effects during construction of the proposed Penelec project would occur intermittently from August 1995 to May 1997 and would be limited primarily to emissions of fugitive dust and exhaust emissions from construction equipment and vehicles. Combustion of diesel fuel and gasoline in medium- and heavy-duty construction vehicles would generate localized emissions of $\mathrm{NO}_{x}, \mathrm{CO}$, and VOCs. Additionally, combustion of diesel fuel would generate localized $\mathrm{SO}_{2}$ and particulate emissions. Heavy construction vehicles, as well as 
vehicles traveling on dirt during construction, would generate fugitive dust emissions. Strong winds acting on the loosened earth would also generate fugitive emissions. Fugitive dust consists primarily of large particles that settle quickly and pose minimal adverse health impacts.

The total surface area to be developed during construction of the proposed project would be about 1 acre. Additionally, a small amount of vacant land (probably less than 5 acres) on the Warren Station site might be disturbed temporarily while being used for laydown of construction materials. Because construction would occur in the existing plant yard, much less site clearing would be necessary than for an undisturbed site. Therefore, levels of fugitive dust emissions should be relatively low. As a mitigation measure, open construction areas would be sprinkled with water (ASC 1993) to reduce fugitive dust emissions by approximately 50\% (Jutze, Axetell, and Parker 1974). In summary, minimal air quality impacts would be expected during the construction period.

\subsubsection{Operation}

During the demonstration, annual air emissions from the repowered Unit 2 would include approximately 821 tons of $\mathrm{SO}_{2}, 603$ tons of $\mathrm{NO}_{x}, 73$ tons of particulate matter, and 3 tons of VOCs. As shown in Table 3.1, these emissions would be less than corresponding emissions from the existing Unit 2. Similarly, plantwide emissions from the combined operation of the repowered Unit 2 and existing Unit 1 would be less than current plantwide emissions. Although the annual emissions of $\mathrm{CO}$ from the repowered Unit 2 cannot be quantified, they are expected to be less than the 76 tons released from the existing Unit 2 . 
Ozone is not directly produced by combustion but forms in the atmosphere because of complex photochemical reactions between $\mathrm{NO}_{x}$ and VOCs in the presence of sunlight. Because $\mathrm{NO}_{x}$ and VOC emissions would decrease with the proposed project, ozone formation would also likely decrease.

Although annual emissions would be lower and the stack would be raised for the proposed project, the temperature at which the effluent exits the stack would be less because of the FGD dry scrubber and the baghouse, thereby reducing plume rise. Decreased plume rise would partially offset the benefits achieved by the lower emissions and raised stack because it would allow for less dilution of the plume before it contacts the ground. To determine the net effects of these changes in the ambient air (at and beyond the Warren Station boundary), a simplified EPA screening model for air dispersion (SCREEN2) was used. SCREEN2 was run to estimate ambient ground-level concentrations in simple terrain (terrain with elevations below the stack height), complex terrain (terrain with elevations above the plume centerline height), and intermediate terrain (terrain with elevations between the stack height and the plume centerline height) (EPA 1991). Table 5.1 gives the emission and stack parameters input to the SCREEN2 model for the existing Unit 2 and the repowered Unit 2 (alone and in combination with Unit 1). To form an upper bound, future $\mathrm{SO}_{2}$ emissions from Unit 1 were based on the proposed increase of the emission limit from the current limit of $3.0 \mathrm{lb} / \mathrm{MMB}$ tu to a limit of $3.47 \mathrm{lb} / \mathrm{MMBtu}$ (see Sect. 3.2).

Maximum modeled concentrations in the ambient air from emissions of the repowered Unit 2 (operating alone) are compared in Table 5.2 with those of the existing Unit 2 (operating alone). During the demonstration, the model predicts that maximum $\mathrm{SO}_{2}$ concentrations would 
Table 5.1. Stack and emission parameters input into the SCREEN2 model for the existing Unit 2 and the repowered Unit 2 at Warren Station (alone and in combination with Unit 1)

\begin{tabular}{lcc|cc}
\hline Parameter & $\begin{array}{c}\text { Existing } \\
\text { Unit 2 }\end{array}$ & $\begin{array}{c}\text { Repowered } \\
\text { Unit 2 }\end{array}$ & $\begin{array}{c}\text { Existing } \\
\text { Units 1 and 2 }\end{array}$ & $\begin{array}{c}\text { Existing Unit 1 and } \\
\text { repowered Unit 2 }\end{array}$ \\
\hline Stack height $(\mathrm{m})$ & 61 & 95 & 61 & 95 \\
Stack inside diameter $(\mathrm{m})$ & 4.7 & 4.7 & 4.7 & 4.7 \\
Stack exit temperature $(\mathrm{K})$ & 474 & 342 & 481 & 399 \\
Stack exit velocity $(\mathrm{m} / \mathrm{s})$ & 7.7 & 7.2 & 13.5 & 14.9 \\
$\mathrm{SO}_{2}$ emission rate $(\mathrm{g} / \mathrm{s})^{a}$ & $225^{b}$ & 28 & $449^{b}$ & $288^{c}$ \\
$\mathrm{NO}_{\mathbf{x}}$ emission rate $(\mathrm{g} / \mathrm{s})^{d}$ & $47^{b}$ & 20 & $95^{b}$ & 67 \\
Particulate emission rate $(\mathrm{g} / \mathrm{s})$ & $8^{b}$ & 2 & $20^{b}$ & 10 \\
\hline
\end{tabular}

${ }^{a} \mathrm{SO}_{2}=$ sulfur dioxide.

${ }^{5}$ Short-term emission rates for existing Units 1 and 2 were calculated from 1992 annual emissions assuming $4620 \mathrm{~h}$ of operation at full load, which approximates historical operating conditions.

Future $\mathrm{SO}_{2}$ emissions for Unit 1 were calculated assuming an increase of the emissions limit from the current limit of $3.0 \mathrm{lb} / \mathrm{MMB}$ tu to a limit of $3.47 \mathrm{lb} / \mathrm{MMBtu}$.

${ }^{\mathrm{NO}} \mathrm{z}=$ oxides of nitrogen.

decrease by $85 \%$ (compared with the existing Unit 2), maximum $\mathrm{NO}_{\mathrm{x}}$ concentrations would decrease by $48 \%$, and maximum particulate concentrations would decrease by about $64 \%$. Additionally, Table 5.2 displays the maximum modeled concentrations for the combined operation of the existing Unit 1 and repowered Unit 2, as compared with those for the existing Units 1 and 2. During the combined Unit 1 and repowered Unit 2 operation, maximum $\mathrm{SO}_{2}$ concentrations would decrease by $40 \%$, maximum $\mathrm{NO}_{\mathrm{x}}$ concentrations would decrease by $33 \%$, and maximum particulate concentrations would decrease by about $52 \%$. The results of the SCREEN2 model are estimates that overpredict actual ambient concentrations (58 FR 137 1993). However, the results are useful in predicting whether proposed changes would result in net improvement or deterioration of air quality. For the proposed Penelec project, the changes 
Table 5.2. Maximum modeled concentrations in the ambient air from emissions of the existing Unit 2 and the repowered Unit 2 at Warren Station (alone and in combination with Unit 1)

\begin{tabular}{|c|c|c|c|c|c|c|c|}
\hline \multirow[b]{2}{*}{ Pollutant } & \multirow[b]{2}{*}{$\begin{array}{l}\text { Averaging } \\
\text { period }\end{array}$} & \multicolumn{2}{|c|}{$\begin{array}{l}\text { Maximum modeled concentration } \\
\qquad\left(\mu \mathrm{g} / \mathrm{m}^{3}\right)\end{array}$} & \multirow[b]{2}{*}{$\begin{array}{l}\text { Percent } \\
\text { change }\end{array}$} & \multicolumn{2}{|c|}{$\begin{array}{l}\text { Maximum madeled concentration } \\
\qquad\left(\mu \mathrm{g} / \mathrm{m}^{3}\right)\end{array}$} & \multirow[b]{2}{*}{$\begin{array}{l}\text { Percent } \\
\text { change }\end{array}$} \\
\hline & & $\begin{array}{l}\text { Existing } \\
\text { Unit } 2\end{array}$ & $\begin{array}{l}\text { Repowered } \\
\text { Unit } 2\end{array}$ & & $\begin{array}{c}\text { Existing Units } 1 \\
\text { and } 2\end{array}$ & $\begin{array}{l}\text { Existing Unit } 1 \text { and } \\
\text { repowered Unit } 2\end{array}$ & \\
\hline \multirow[t]{3}{*}{$\mathrm{SO}_{2}^{b}$} & $3-h$ & 5022 & 743 & -85 & 7759 & 4659 & -40 \\
\hline & $24-h$ & 1395 & 206 & -85 & 2155 & 1294 & -40 \\
\hline & annual $^{\mathrm{c}}$ & 558 & 83 & -85 & 862 & 518 & -40 \\
\hline $\mathrm{NO}_{\mathrm{x}}{ }^{d}$ & annual $^{c}$ & 117 & 61 & -48 & 181 & 121 & -33 \\
\hline \multirow[t]{2}{*}{ Particulate matter } & $24-\mathrm{h}$ & 49 & 18 & -63 & 97 & 46 & -53 \\
\hline & annual ${ }^{c}$ & 20 & 7 & -65 & 39 & 19 & -51 \\
\hline
\end{tabular}

${ }^{a}$ Concentrations were determined using the SCREEN2 air dispersion model (EPA 1991).

${ }^{b} \mathrm{SO}_{2}=$ sulfur dioxide.

'Annual concentrations are based on full-time operation; actual concentrations would be less, especially for Unit 1 and the existing Unit 2 because their capacity factor has historically been only about $53 \%$. Consequently, the percentage change (for the repowered Unit 2 vs the existing unit 2 ) would be less pronounced if the capacity factor were incorporated into the comparison. For example, annual $\mathrm{SO}_{2}$ concentrations for the existing Unit 2 would be $294 \mu \mathrm{g} / \mathrm{m}^{3}$, annual $\mathrm{SO}_{2}$ concentrations for the repowered Unit 2 would be $71 \mu \mathrm{g} / \mathrm{m}^{3}$, and the percentage change would be -76 . Annual concentrations in this table are based on full-time operation because the SCREEN2 model cannot estimate concentrations during the combined operation of Units 1 and 2 for less than fulltime operation. A more sophisticated model would be required, but is not necessary for this analysis.

$\mathrm{NO}_{\mathrm{x}}=$ oxides of nitrogen. 
in maximum $\mathrm{SO}_{2}, \mathrm{NO}_{\mathrm{x}}$, and particulate concentrations would clearly be beneficial. Furthermore, results of the modeling indicate that improvement would occur in the entire region surrounding Warren Station. Ambient concentrations were not modeled for $\mathrm{CO}$ and specific VOCs because emission rates have not been established for these pollutants.

Because annual operating time for the repowered Unit 2 would increase, annual mercury emissions at Warren Station would rise by $34 \%$ from $32 \mathrm{~g}$ to $43 \mathrm{~g}$. These increased emissions are very small, and concentrations at the stack exit would be nearly two orders of magnitude lower than the EPA reference guideline for annual ambient air concentrations for mercury $\left(0.3 \mu \mathrm{g} / \mathrm{m}^{3}\right)$ (40 CFR Pt. 266, App. IV). Therefore, ground-level concentrations at and beyond the site boundary (typically $0.1 \%$ of concentrations at the stack exit) would be well below the EPA guideline for mercury. Ambient concentrations of other pollutants, including air toxics, resulting from the proposed project should be minimal.

In summary, the proposed project is expected to improve the overall air quality of the surrounding region (including the Allegheny National Forest). The proposed project would not affect air quality at the Dolly Sodds Wilderness Area (the nearest PSD Class I area), located 200 miles to the south, because of the large distance from Warren Station and low frequency of northerly wind in the region (see Fig. 4.1).

\subsubsection{Global climate change}

A major worldwide environmental issue is the possibility of appreciable changes in the global climate (e.g., global warming) because of increasing atmospheric concentrations of "greenhouse" gases, especially $\mathrm{CO}_{2}$ (Mitchell 1989). Because $\mathrm{CO}_{2}$ is stable in the atmosphere 
and essentially uniformly mixed throughout the troposphere and stratosphere, the climatic impact does not depend on the geographic location of sources. Therefore, an increase in $\mathrm{CO}_{2}$ emissions at a specific source is effective in altering $\mathrm{CO}_{2}$ concentrations only to the extent that it contributes to the global total produced by energy use.

As shown in Table 3.1, the proposed project would increase annual $\mathrm{CO}_{2}$ emissions at Warren Station by $36 \%$. This annual increase of 206,000 tons is equivalent to $0.001 \%$ of the annual total emitted by global fossil fuel combustion. However, Penelec is expected to require less use of its units at other sites because of the increased efficiency and power-generating capability of the repowered Unit $2(73 \mathrm{MW}$ vs the existing $48 \mathrm{MW})$. Because of this increased efficiency and capacity, Penelec probably would choose to decrease the use of its older, lessefficient units that require more coal and emit more $\mathrm{CO}_{2}$ for a given amount of electricity than the repowered Unit 2. Therefore, the predicted increase in $\mathrm{CO}_{2}$ emissions at Warren Station would be offset by a reduction in total $\mathrm{CO}_{2}$ emissions over the Penelec system and, consequently, could result in lower global emissions of $\mathrm{CO}_{2}$.

\subsubsection{Water Resources}

This section discusses potential effects on surface water resources, groundwater resources, floodplains, and wetlands. 


\subsubsection{Surface water resources}

Excavation and earthwork during construction of the proposed 1-acre facility would disturb a small portion of the Warren Station reservation. Construction would disturb soils and increase the potential for runoff, erosion, and sedimentation near the site. Standard engineering practices such as straw berms, liners, cover materials, and grading would be implemented to control runoff. Uncontrolled runoff into the Allegheny River would be minimal. No impacts would be expected because the river has a relatively large minimum flow of $500 \mathrm{ft}^{3} / \mathrm{s}$ (224,000 gpm) maintained by releases from Kinzua Dam. Accidental spills of construction materials such as solvents, paint, sealer, caulk, oil, and grease that could contain hazardous substances would be cleaned up in a timely manner so that runoff to the river or seepage into the ground would be mitigated. Impacts from accidental spills would be minimal.

Water consumption would increase by $107 \mathrm{gpm}$ during operation of the proposed project (ASC 1993). Approximately two-thirds of this increase would be supplied by PAWC with water obtained from groundwater and induced infiltration from the river, and the remainder would be supplied directly by the Allegheny River. The increased water requirements would not deplete the PAWC water supply because excess capacity is at least $1300 \mathrm{gpm}$ (Tom Peterson, PAWC, Warren, Pennsylvania, personal communication with R. L. Miller, ORNL, Oak Ridge, Tennessee, January 14, 1994). Similarly, the increased surface water requirements would not impact the Allegheny River, whose $500 \mathrm{ft}^{3} / \mathrm{s}(224,000 \mathrm{gpm})$ minimum flow is regulated by Kinzua Dam and maintained by storage in Allegheny Reservoir (COE 1975).

Presently, condenser cooling water is taken from the Allegheny River, is heated while passing through the facility, and is retumed to the river. The total flow entering the two 
condensers is $131 \mathrm{ft}^{3} / \mathrm{s}(58,800 \mathrm{gpm})$ (ASC 1993). The proposed project would not affect the flow of condenser cooling water or heat discharge rate to the river. However, the annual operating time for the repowered Unit 2 is expected to increase by about $60 \%$ over the existing Unit 2's $4620 \mathrm{~h}$ (based on 1992 operating conditions) to $7500 \mathrm{~h}$ out of a possible $8760 \mathrm{~h}$ per year.

The existing heat rejection rate is within the NPDES permit limit of $186,780 \mathrm{~kW}$ $\left(15,306 \times 10^{6} \mathrm{Btu} / \mathrm{day}\right)$. The NPDES heat rejection rate was established based on calculations allowing a maximum river water temperature of $87^{\circ} \mathrm{F}$ downstream of the discharge and a maximum increase in river water temperature of $5^{\circ} \mathrm{F}$ caused by cooling the condensers (ASC 1993). The NPDES limit was formulated using the total 10-year, 7-day Allegheny River low flow of $579 \mathrm{ft}^{3} / \mathrm{s}(260,000 \mathrm{gpm})$ in compliance with PaDER Title 25 Rules and Regulations (PaDER 1980, 1989a, 1989b).

The existing thermal plume from Warren Station extends from the condenser outlet into the shallow outfall channel and flows around both sides of the small unnamed island (see Fig. 3.2). Rapid cooling occurs after the flow in the main channel intercepts the plume at and beyond the small island (Bogan 1994). An analysis was performed using a steady-flow energy balance that accounts for the heat that the proposed facility would reject to the river (the same heat rejection rate as the existing facility). River water in the main channel passing north of Mead Island would be available to dilute the thermal plume, while river water passing south of Mead Island would not be available (see Fig. 3.1). The fraction of river water in the main channel passing north of Mead Island is not known exactly, but it is much more than the fraction passing south of Mead Island. As a very conservative estimate of the split of the river flow around Mead Island, the 10-year, 7-day low flow [579 $\left.\mathrm{ft}^{3} / \mathrm{s}(260,000 \mathrm{gpm})\right]$ was divided 
into two equal flows [290 $\left.\mathrm{ft}^{3} / \mathrm{s}(130,000 \mathrm{gpm})\right]$ passing on each side of Mead Island. The analysis indicates that water temperatures in the main channel would occasionally exceed $87^{\circ} \mathrm{F}$ and could reach a maximum of $91^{\circ} \mathrm{F}$. These temperatures would be reached less than $10 \%$ of the time because the total river flow exceeds $1580 \mathrm{ft}^{3} / \mathrm{s}(709,000 \mathrm{gpm}) 90 \%$ of the time, the discharge from Kinzua Dam is relatively cool (because water exits near the bottom of Allegheny Reservoir), and the climate is also relatively cool (see Sect. 4.1.1). Furthermore, the analysis forms an upper bound of potential water temperatures because much more than onehalf of the total flow is actually available in the main channel to mix with the discharge.

Two ash ponds serve as settling basins for liquid wastes generated at Warren Station. Concrete weirs decant excess supernatant and discharge into the Allegheny River in accordance with NPDES permit limitations. The ash sluicing system, nunoff from the ash disposal area, neutralized coal pile runoff, neutralized demineralizer wastewater, and plant general sump discharge to the ash ponds. The plant general sump collects equipment cooling water, bottom ash hopper discharges, precipitator sludge blowdown, filter backwash, spent water softeners, flows from equipment floor drains, evaporator blowdown, and boiler blowdown. The proposed project would not increase the volumetric flow discharged to the ash ponds.

The leachability of fly ash constituents determines the potential for water quality impacts. Fly ash is more leachable than bottom ash, which is a glassy, vitrified, granular, relatively inert, nearly insoluble solid. The surface area of the fused bottom ash is much smaller than that of an equal volume of fine-grained fly ash. The larger fly ash surface area promotes leaching. Fly ash leachate would be expected to contain trace inorganics such as boron, arsenic, copper, zinc, chromium, lead, molybdenum, nickel, titanium, and vanadium 
(Zubovic 1976). The precise quantity and type of trace inorganics depend on the composition of coal burned at the facility. The rate at which trace inorganics would be discharged into the Allegheny River from the ash ponds at Warren Station would decrease by about $50 \%$ in proportion to the $50 \%$ decrease in fly ash being conveyed to the ponds (Sect. 3.1.2.6). Improved Allegheny River water quality would reflect the reduced influx of trace inorganics.

Warren Station currently is authorized by PaDER and the EPA to discharge effluent into the Allegheny River under conditions specified in NPDES permit 0005053 (including Amendment No. 1) in accordance with the Clean Water Act (PaDER 1991; ASC 1993). The NPDES permit regulates the discharge to the river of residual chlorine $(0.2 \mu \mathrm{g} / \mathrm{L}$ instantaneous maximum), total suspended solids ( $30 \mu \mathrm{g} / \mathrm{L}$ monthly average and $100 \mu \mathrm{g} / \mathrm{L}$ daily maximum), oil and grease (15 $\mu \mathrm{g} / \mathrm{L}$ monthly average, $20 \mu \mathrm{g} / \mathrm{L}$ daily maximum, and $30 \mu \mathrm{g} / \mathrm{L}$ instantaneous maximum), $\mathrm{pH}$ (6.0 to 9.0 standard units at all times), and heat $\left(15,306 \times 10^{6} \mathrm{Btu} / \mathrm{day}\right.$ monthly average total from both units). Monitoring is performed to ensure compliance with NPDES permit limits.

Demineralizer wastewater would be rerouted to the coal pile runoff neutralization system for treatment prior to release at the ash pond outfalls. The NPDES permit may require modification to accommodate demineralizer wastewater (ASC 1993).

Construction and operation of the North and South Ash Disposal Sites have already altered the hydrologic environment of the unnamed creek between the ash ponds (see Fig. 3.2). The proposed project would cause no additional impacts to the flow and water quality of the creek. 


\subsubsection{Groundwater resources}

The quantity and properties of the solid waste produced at Warren Station would change during the proposed project. Currently, both the fly ash and bottom ash are sluiced into the ash ponds (21,000 tons/year for the two units) before being placed in the South Ash Disposal Site (GAI 1993b). Under the proposed project, solid waste from the two units would increase by $118 \%$ to 45,730 tons/year (see Table 3.1 ). Of this, 30,720 tons/year would be fly ash and scrubber waste from the repowered Unit 2 , which would be conveyed to an on-site silo for interim storage before transfer by truck to the ash disposal site (without being sluiced into the ash ponds) (ASC 1993). About 15,010 tons/year of ash (10,500 tons/year of fly ash and bottom ash from Unit 1 and 4510 tons/year of bottom ash from Unit 2) would continue to be sluiced into the ash ponds before disposal.

As at many other coal-fired power plants, the ash disposal sites and ash ponds at Warren Station are unlined. Groundwater investigations near the ash disposal sites have indicated that some of the regulated groundwater parameters such as sulfate and dissolved iron exceeded their Mandatory Abatement Trigger Levels (GAI 1993a). The groundwater beneath the ash ponds probably has been affected similarly. As a result, a groundwater assessment plan for determining the source(s) of these occurrences was submitted to PaDER in June 1993. While the impacts on the groundwater from current operations are unclear, the new PRWMRs require that Penelec either apply for modification of the presently permitted ash disposal facilities or close them (see Sect. 3.2). In consultation with PaDER, Penelec has committed to installing liners at the active ash disposal site and ash ponds in 1996 and 1997, respectively (Gray 1994). The active ash disposal site would be lined first (before the start of the 
demonstration in November 1996) because the fly ash and scrubber waste from the repowered Unit 2 would be delivered dry to the ash disposal site and thus would have the potential to produce more concentrated leachate and be a greater source of groundwater degradation (if the site remained unlined) than sluiced ash at the ash ponds. In addition, the scrubber waste would contain more calcium sulfate, heavy metals, and organic compounds than the currently generated ash contains. The installation of liners at the facilities should prevent constituents from leaching into the groundwater. Reduced impacts are expected because groundwater quality would improve after Penelec meets the new requirements of PaDER.

The groundwater is not being monitored near the unlined coal pile at Warren Station. Although the coal pile runoff is collected, treated in a neutralization system, and discharged to the ash ponds, it is possible that coal pile acidic leachate with elevated levels of iron, dissolved solids, sulfate, and possibly some trace metals may reach the groundwater (OECD 1983). The existence or extent of this effect at Warren Station is unknown. However, under the proposed project, the existing coal receiving and storage facilities would be used without modification. Because the increased coal consumption would only change the coal shipment from the current 210 to about 280 truck loads per week and would not affect the size of the coal pile, any impacts to the groundwater as a result of coal pile runoff would not increase during the proposed project.

\subsubsection{Floodplains and wetlands}

Construction of the proposed Penelec project would occur outside of the 500-year floodplain; therefore, no impacts would be expected. Operations during the proposed project 
would not affect existing on-site structures such as the ash ponds, whose surrounding berms rise above the 100 -year floodplain but are below the 500 -year floodplain.

Construction and operation of the proposed project would not disturb the existing wetland. No surveys are required to identify additional wetlands.

\subsubsection{Ecological Resources}

This section discusses potential effects on terrestrial and aquatic ecology, including threatened and endangered species and biodiversity.

\subsubsection{Terrestrial ecology}

The small acreage that would be affected by construction activities ( 1 acre for the building addition and no more than 5 acres for construction laydown) has previously been disturbed and has no important plant or animal resource (see Sect. 4.3.1). Construction would not affect the relatively undisturbed habitats on the site. Construction noise and activities would have negligible impact on wildlife because no important wildlife resource is located near the proposed site and because any nearby wildlife would be accustomed to activities and associated noise at the existing facility. Therefore, impacts of construction for the proposed project would be negligible.

Operation of the proposed project would not cause appreciable changes in land use (Sect. 5.1.4) or terrestrial habitats on the Warren Station site; the area used for ash disposal 
activities is expected to increase only slightly. Any effect on terrestrial plant and animal resources resulting from noise and air emissions from project operation would be negligible.

\subsubsection{Aquatic ecology}

Construction would disturb about 1 acre of the existing 96-acre Warren Station site and would increase the potential for runoff, erosion, and sedimentation in the Allegheny River near the site. Standard erosion and sediment control measures and ongoing measures to prevent or reduce pollution at the site in compliance with the Pollution Prevention Act of 1990 (ASC 1993) (see Sect. 5.1.13) would minimize sediment movement and any potential impacts to aquatic biota. Accidental spills of construction-related materials such as solvents, oil, and grease would be cleaned up as specified in the existing spill control plans (ASC 1993). Therefore, these materials would not be available for transport into the river and would not affect aquatic biota.

During operation, water requirements for the proposed project would increase Warren Station water usage by 107 gpm (ASC 1993), a 0.2\% increase. Approximately one-third of this increased demand would be supplied from the Allegheny River. An increased withdrawal of $35 \mathrm{gpm}$ from the river, which is only a $0.06 \%$ increase, is expected to result in a similarly small percentage increase in entrainment (uptake of small organisms in the water) and impingement (entrapment of large organisms on the screens of intake structures). There should be little effect on aquatic biota in the river, even at a minimum release of $500 \mathrm{ft}^{3} / \mathrm{s}$ (224,000 gpm) from Kinzua Dam. 
The existing thermal plume from Warren Station extends from the condenser outlet into the outfall channel, passes on both sides of the small unnamed island, and cools rapidly after the flow in the main channel intercepts the plume (see Fig. 3.2). The proposed project would not affect the temperature of the plume or the plume's areal extent. The maximum thermal tolerance for most fish species found in the Warren vicinity, either originating in the upper Allegheny River or from Conewango Creek, ranges from 85 to $88^{\circ} \mathrm{F}$ (Jones 1964). The temperatures in the outfall channel and narrow channel between Warren Station and the small unnamed island occasionally exceed the thermal tolerance for many of these species (Bogan 1994). Intolerant and relatively immobile fish or macroinvertebrates entering these channels could be trapped and killed in the thermal plume. However, the mussel survey by Bogan (1994) found adults of four species of mussels residing in the outfall channel. Because of the small size of the channels, use by fish is expected to be minimal compared with the main channel of the river (see Fig. 3.2). Mobile species are expected to be capable of avoiding these areas of elevated temperatures (Marcy and Thorpe 1976). A very conservative analysis for the proposed project indicated that the water temperature in the main channel downstream of the outfall could reach a maximum of $91^{\circ} \mathrm{F}$ at a flow of $290 \mathrm{ft}^{3} / \mathrm{s}(130,000 \mathrm{gpm})$, a flow equal to half the 10-year, 7-day low flow of the Allegheny River (see Sect. 5.1.2.1). Because the thermal plume extends downstream on the main channel's north side only, those species preferring cold-water habitats can avoid the plume by staying in the unaffected portion of the main channel. Some species may actively seek the heated plume, especially during winter (Langford 1983).

No incidents to aquatic life have been reported as a consequence of the existing thermal plume in over 40 years of Warren Station operation. Except for an approximately $60 \%$ 
increase in the annual operating time of the repowered Unit 2, there would be no change in the thermal discharge from Warren Station associated with the proposed project. No appreciable change is expected from increased annual exposure of the aquatic species to the thermal plume. The potential for impacts to aquatic biota would be minimized by dilution of the thermal plume during river flows that exceed $1580 \mathrm{ft}^{3} / \mathrm{s}(709,000 \mathrm{gpm}) 90 \%$ of the time. Penelec will comply with whatever heat rejection rate or temperature limits are established after reevaluation of its NPDES permit by PaDER in 1996 (PaDER 1991; ASC 1993).

An approximate $50 \%$ reduction in the amount of fly ash discharged to the ash ponds (see Sect. 3.1.2.6) would result in a corresponding decrease of about $50 \%$ in the rate of trace metal discharge from Warren Station and an improvement in the water quality of the Allegheny River. Therefore, any potential chronic effects of leachate from trace metals on aquatic biota would be decreased as a result of the proposed project.

Compliance with the NPDES permit requirements for residual chlorine, total suspended solids, oil and grease, and $\mathrm{pH}$ (which are set lower than levels known to have an effect on aquatic biota) would minimize the potential effects of adverse water quality on aquatic biota. NPDES permit requirements also regulate stormwater runoff; consequently, the effects of sediment transport from Warren Station should be minimal. Demineralizer wastewater from the proposed project would be treated before discharge to the ash pond outfall and would be regulated by modification of the NPDES permit (see Sect. 5.1.2.1). After dilution in the river, concentrations of constituents would decrease. Therefore, the potential for effects on aquatic biota in the main channel of the Allegheny River would be further decreased. 


\subsubsection{Threatened and endangered species}

Construction and operation of the proposed project should not affect the few bald eagles that reside during the winter along the Allegheny River in the Warren area. Construction disturbance to any eagles along the river should be negligible because the river in the site vicinity does not appear to be of above average importance to eagles. Further, construction would be (1) temporary, (2) located on the north side of the existing plant facing away from the river, and (3) located at least $500 \mathrm{ft}$ from the river. Operation of the proposed project would not adversely affect the eagle's food resource (primarily fish), because the river's hydrology would not be appreciably affected and its water quality would be improved (Sect. 5.1.2.1).

By improving the water quality of the Allegheny River, the proposed project may reduce the potential for impacts from effluent discharge for any threatened or endangered aquatic species in the vicinity of Warren Station (Sect. 4.3.3). Thermal plume effects on any protected species would remain unchanged from existing conditions, except for increased annual exposure because of the increased annual operating time of the repowered Unit 2. Protected fish species and the Ohio lamprey which may occur in the river (Kulp 1994; Shiels 1994) should be able to avoid the thermal plume by staying in the unaffected portion of the main channel. During the mussel survey, no endangered northem riffleshell and clubshell mussels were found in the outfall channel, in the narrow channel between Warren Station and the small unnamed island, or in the river upstream and downstream of the thermal discharge (Bogan 1994). Therefore, there would be no effect on these species from the continued discharge at Warren Station. The U.S. Fish and Wildlife Service has concurred with this 
finding and has stated that no further consultation under Sect. 7 of the Endangered Species Act is required (see Appendix B).

\subsubsection{Biodiversity}

Construction and operation of the proposed project would have minimal impacts on biota, as discussed in the previous sections. Therefore, the impact on biodiversity would be negligible.

\subsubsection{Land Use}

The primary change in land use on the Warren Station site would be an approximate 1-acre increase in the amount of developed area, resulting from the building addition for the proposed project. Also, construction activities would temporarily disturb less than 5 acres of currently vacant land on the site. Because the Warren Station site is zoned as industrial, these land uses would be consistent with Warren County zoning. No prime farmland would be affected by construction because none is located on the Warren Station site (see Sect. 4.4). Effects on land use off the site are not expected during construction.

Operation of the proposed facility would be consistent with the industrial zoning of the adjacent land areas. The amount of land used for coal storage, ash handling and disposal, and other operations would not change appreciably. The amount of land used for operations related to ash disposal could increase only slightly because very little (if any) unused land would be available for additional disposal adjacent to the existing South Ash Disposal Site. 
The capacity of the ash disposal site would be depleted at a faster rate as a result of the proposed project because of increased coal use and ash production. The two existing units annually produce about 21,000 tons of solid waste, whereas about 45,700 tons would be produced at Warren Station under the proposed project (see Table 3.1). Calculations indicate that the existing area at the South Ash Disposal Site would easily accommodate this increased level of solid waste production during the period of the demonstration from November 1996 through August 1999. The calculations assume a solid waste density of $75 \mathrm{lb} / \mathrm{ft}^{3}$ and assume that waste would be piled $36 \mathrm{ft}$ high on average, as anticipated by the project participant. No effects on land use outside the Warren Station site are expected. Section 5.3 considers land availability during the combined period of the demonstration and commercial operation.

\subsubsection{Waste Management}

This section discusses potential impacts from solid, liquid, and sanitary wastes.

\subsubsection{Solid wastes}

The 20-acre South Ash Disposal Site, regulated by PaDER solid waste permit 300858 (ASC 1993), is the only permitted solid waste landfill still in use at Warren Station. Solid wastes approved for disposal include fly ash, bottom ash, pyritic refuse, coal pile drainage sludge, asphalt, stones, rock, concrete, brick, and soil. The Warren Station ash ponds are cleaned once annually, and the resulting solids (primarily fly ash and bottom ash) from the bottom of the ash ponds are transported to the on-site landfill for disposal. The landfill also 
receives spent fireclay brick used to insulate boiler walls. The landfill consists of a series of terraces which, when filled, are covered with soil and seeded. Soil is obtained from a private sand and gravel company located on Mead Island.

The quantities of fly ash, bottom ash, and scrubber residuals generated annually at Warren Station would increase during operation of the proposed project (see Table 3.1). Sections 5.1.4 and 5.3 discuss land availability for disposal of solid waste. Fly ash is exempted from the Resource Conservation and Recovery Act (RCRA), as amended [40 CFR 261.4(b)(4) and 40 CFR 266.112], and disposal requires no RCRA permit because fly ash is not considered to be hazardous waste. The EFCC scrubber residuals would consist of hydrated calcium sulfite, calcium sulfate, calcium hydroxide, and various inert solids. Disposal of scrubber residuals in the South Ash Disposal Site could require modification of PaDER solid waste permit 300858 . As part of a permit modification, chemical analysis of the fly ash generated by the proposed project may be required to determine RCRA classification as a basis to select disposal options.

Solid wastes such as wood, cardboard, and glass generated by construction activities are transported to the McKean County landfill by Valentine Disposal Company for disposal. The landfill is regulated under PaDER solid waste permit 100-361. Sufficient unfilled capacity would be available to receive increased quantities of solid wastes generated during construction of the proposed project.

Soils contaminated with fuel oil, contaminated absorbent pads, and asbestos-containing materials are handled and disposed of off-site by licensed contractors in accordance with federal and state solid waste regulations. The quantities of these wastes that would be 
generated during construction and operation of the proposed project would not add appreciably to the quantities already being generated at Warren Station.

The decommissioned boilers would remain on-site at Warren Station. Dismantling and disposal would not occur until the entire plant was decommissioned.

PaDER issued new PRWMRs, which became effective July 4, 1992 (ASC 1993). Existing or proposed facilities that are or will be required to have a residual waste permit must obtain a permit modification under the new PRWMRs following an established schedule. Facility upgrades may be required at Warren Station to achieve compliance with new regulations.

\subsubsection{Liquid wastes}

Licensed contractors handle and dispose of solvents, waste oils, fuel oil spills, and other miscellaneous liquid wastes in accordance with federal and state liquid waste regulations. Quantities of liquid wastes that would be generated during construction and operation of the proposed project would not add appreciably to the quantities now being produced at Warren Station (approximately one 55-gal drum per month).

\subsubsection{Sanitary wastes}

Sanitary wastes flow to an underground septic tank, which in turn discharges to an onsite drain field. Increased sanitary wastes generated during construction would be accommodated using portable toilets. Expansion of the septic system would not be required for 
the proposed project. The 4-gpm flow discharged into the septic system would not increase during operation of the proposed project (ASC 1993).

\subsubsection{Archaeological and Cultural Resources}

Archaeologists performed a cultural resources survey of the Warren Station site to evaluate the potential effects of the proposed project on archaeological and cultural resources (Fiedel and Klein 1994a). The survey included a walkover reconnaissance of the proposed construction site and three related areas on December 15, 1993, with Stanley Lantz, who has excavated the existing dig site (Bureau for Historic Preservation Site 36 Wa 152) (see Sect. 4.5).

Recommendations from the survey included no further investigation of the proposed construction site because it already has been extensively disturbed and graded. The survey team also suggested that a plan be developed for dealing with unanticipated finds during construction.

The three areas related to construction activities which were examined during the survey included two areas for laydown of construction materials and equipment and a new access road for coal delivery. Because the eastern edge of the proposed eastem laydown area was almost adjacent to Site $36 \mathrm{Wa} 152$, it was removed from consideration as a laydown area. The northern laydown area lies east of the plant access road between the active railroad tracks to the south and U.S. Highway $6 / 62$ to the north (see Fig. 3.2). The survey team recommended a shovel test for the eastem section of this area at $45-$ to $75-\mathrm{ft}$ intervals. Because the westem section of the laydown area has been previously disturbed, no further investigation was 
suggested. The new access road for coal delivery would be adjacent to the northem laydown area (see Fig. 3.2). The recommendation for shovel testing the eastem section of the laydown area would also apply to the eastern section of the road.

The Pennsylvania Bureau for Historic Preservation reviewed the survey recommendations and concurred, with the following exception (Carr 1994). For the northem laydown area, the bureau recommended shovel testing at 45 -ft intervals.

A second cultural resources survey of the Warren Station site was performed on October 12 and 13, 1994, in accordance with the bureau recommendations (Fiedel and Klein 1994b). Shovel testing indicated that the area has suffered extensive prior disturbance. No prehistoric or historic remains were found. No additional work was recommended. The Pennsylvania Bureau for Historic Preservation reviewed the survey recommendations in accordance with Sect. 106 of the National Historic Preservation Act and agreed that no further archaeological investigation is necessary (see Appendix B).

\subsubsection{Socioeconomic Resources}

Construction employment for the proposed Penelec project would last about 18 months, with a construction force ranging from about 75 to 250 workers and peak employment occurring in 1996. Table 5.3 shows the composition of the peak construction work force. The employment opportunities would be mostly for skilled crafts, and much of the labor would commute to the proposed construction site from Warren and surrounding counties. For instance, the Plumbers and Pipefitters Union for this area is Local 47. This local includes 
Table 5.3. Composition of the peak construction work force

\begin{tabular}{lcc}
\hline Craft & $\begin{array}{c}\text { Workers } \\
\text { at peak }\end{array}$ & Percent \\
\hline Boilermakers & 22 & 9 \\
Carpenters & 23 & 9 \\
Electricians & 41 & 16 \\
Insulators & 6 & 2 \\
Ironworkers & 40 & 16 \\
General laborers & 16 & 6 \\
Millwrights & 8 & 3 \\
Equipment operators & 24 & 10 \\
Plumbers and pipefitters & 52 & 21 \\
Miscellaneous & 20 & 8 \\
\hline
\end{tabular}

Source: Mo Bary, Penelec Project Manager for Black and Veatch, Kansas City, Missouri, personal communication with J. Van Dyke, Oak Ridge National Laboratory, Oak Ridge, Tennessee, November 15, 1993.

Warren and ten other counties in northwestern Pennsylvania. It should easily be able to supply the workers for this job without going outside the Warren jurisdiction (Mo Bary, Penelec Project Manager for Black and Veatch, Kansas City, Missouri, personal communication with J. Van Dyke, ORNL, Oak Ridge, Tennessee, November 15, 1993). In this area, most union members are within commuting distance (1.5-h drive) to the proposed project. Because plumbers and pipefitters are required in the largest numbers, these results can be extended for the other crafts. Therefore, few (if any) construction workers would relocate to Warren County because of this project, causing little (if any) effect on population or housing. A small percentage of workers having long commutes might stay in local motels during the work week. Businesses serving transient needs, such as restaurants, service stations, motels, and convenience stores, could receive a temporary benefit from increased spending during the construction period. 
During operation, the project would provide some income and employment to workers in areas of Pennsylvania supplying coal and lime to the proposed project. The coal would be obtained from Clearfield, Elk, Jefferson, and Clarion counties, all in Pennsylvania. The lime would be supplied from either Centre County, Pennsylvania, or Ashtabula County, Ohio. Expenditures for coal and lime would provide some employment and income in these counties. This would be a positive impact, although not large enough to appreciably affect socioeconomic resources in any of these communities.

During construction, additional traffic would result from the arrival and departure of construction workers. The operating work force would not decrease, so there would be a small net increase in traffic. Also, there would be increased traffic due to delivery of supplies during construction. Currently, U.S. Highway $6 / 62$ does not have any congestion problems (see Sect. 4.6.2). The increased traffic during construction and increased truck delivery of coal and lime after construction would not result in congestion problems or degrade the highway's level of service. Currently, coal is delivered to the plant by truck at the rate of 70 truck loads per day on Monday, Wednesday, and Friday. The proposed project would require an additional 70 trucks per week for coal and 9 trucks per week for lime. However, the additional coal trucks would be scheduled for days that do not now have coal delivery. There would not be a major traffic effect even if all deliveries were limited to 3 days.

The construction work force would have minimal demands on public services. The construction firm would provide sanitary waste services for construction employees. Because there would be little (if any) increase in population, there would be no perceptible effects on public services such as schools, libraries, or residential utility services. 
The proposed project would pay about $\$ 1.5$ million in Public Utility Realty Tax Assessment (PURTA) to the Commonwealth of Pennsylvania over the 1994-1999 period (Bradish 1994). This tax would have little effect on the local governments that include Warren Station within their jurisdiction because the PURTA revenue is not returned exclusively to the local govemments from which it is generated but is spread among all local governments in Pennsylvania (Charles Fisher, Corporation Tax Officer, Pennsylvania Department of Revenue, personal communication with J. W. Van Dyke, ORNL, Oak Ridge, Tennessee, February 11, 1994). The project also would generate a gross receipts tax of $\$ 3.9$ million paid over the 1996-1999 period based on electrical generation. The Commonwealth of Pennsylvania collects this tax, which does not result in local revenues.

In summary, the principal socioeconomic effects from the proposed project would be increased traffic during construction and operation and increased taxes paid by Warren Station. To the extent that this project would allow Warren Station to continue operating, it would sustain the existing employment and income benefits and help stabilize declining population levels.

\subsubsection{Environmental Justice}

Recent studies have suggested that minority communities receive a disproportionately large impact from environmental pollution and hazards (EPA 1992). The Executive Order on Environmental Justice requires that "federal agencies identify the economic and social impacts of major Federal Actions significantly affecting the quality of the environment of minority and low-income communities" in accordance with NEPA. The major impacts of fossil power plants 
are usually considered to result from air emissions released by elevated stacks and dispersed by the atmosphere. Therefore, unlike toxic waste sites, emissions from fossil power plants are frequently not considered a disproportionate threat to nearby residents. Air emissions are not selective in their effects with respect to income or race. For instance, all races and income groups have individuals who suffer from pulmonary disease that may be related to air emissions from burning fossil fuel. The proposed project would reduce most emissions from Warren Station. Therefore, the project would tend to decrease negative environmental effects on air quality.

To the extent that negative environmental effects might occur in Warren County, there is no reason to believe that they would result in disproportionate impacts on minorities or lowincome groups. Only $0.6 \%$ of Warren County's population is nonwhite. Also, while average income in Warren County is somewhat lower than for the United States or the Commonwealth of Pennsylvania, the county also has a lower rate of households with income below the poverty level. This suggests that any effects from the project within Warren County would not systematically impact minority or low-income groups.

\subsubsection{Aesthetics}

The view from U.S. Highway $6 / 62$ would be altered by the construction of two new buildings for the proposed Penelec project. The power island building, housing the new EFCC technology and its auxiliary equipment, would extend from the northem facade of the present service building. The dimensions of this addition would be $270 \mathrm{ft}$ east-west (parallel to the highway), $150 \mathrm{ft}$ north-south, and $125 \mathrm{ft}$ high. A water treatment building, $50 \mathrm{ft}$ east-west, 
$25 \mathrm{ft}$ north-south, and lower than the power island building, would be adjacent to the northem facade of this addition. The new buildings would be visible from the highway and possibly from the Allegheny River on the other side of Warren Station. The height of the existing 200-ft stack, which is the most visible structure on the Warren Station site, would increase to $312 \mathrm{ft}$. The stack would include red lights or strobe lights, depending on the requirements of the Federal Aviation Administration (Kenneth M. Gray, Penelec, personal communication with J. W. Van Dyke, ORNL, November 8, 1994). The raised stack would be more perceptible than the existing stack from the surrounding vicinity, including the Allegheny River, which is used for recreational activities. However, the new buildings and raised stack would be aesthetically compatible with the existing power plant, which is a long-time feature of the area. Therefore, the proposed project would not affect the essential visual characteristics of the area.

\subsubsection{Noise}

Ambient noise levels would increase temporarily in the immediate vicinity of the Warren Station site during construction activities. Figure 5.1 lists typical noise levels emitted by various types of construction equipment. Construction for the proposed project would require use of the following types of equipment: air compressor and compaction equipment, concrete placing equipment, cranes, excavation equipment, trucks, and miscellaneous equipment. Noise would be intermittent and would vary during construction with different activities (e.g., ground clearing and excavation). Noise from construction could be above background for the area and would likely be perceptible to the nearest residents. Backup alarms from trucks would be distinctly audible over background transport noise. However, the 


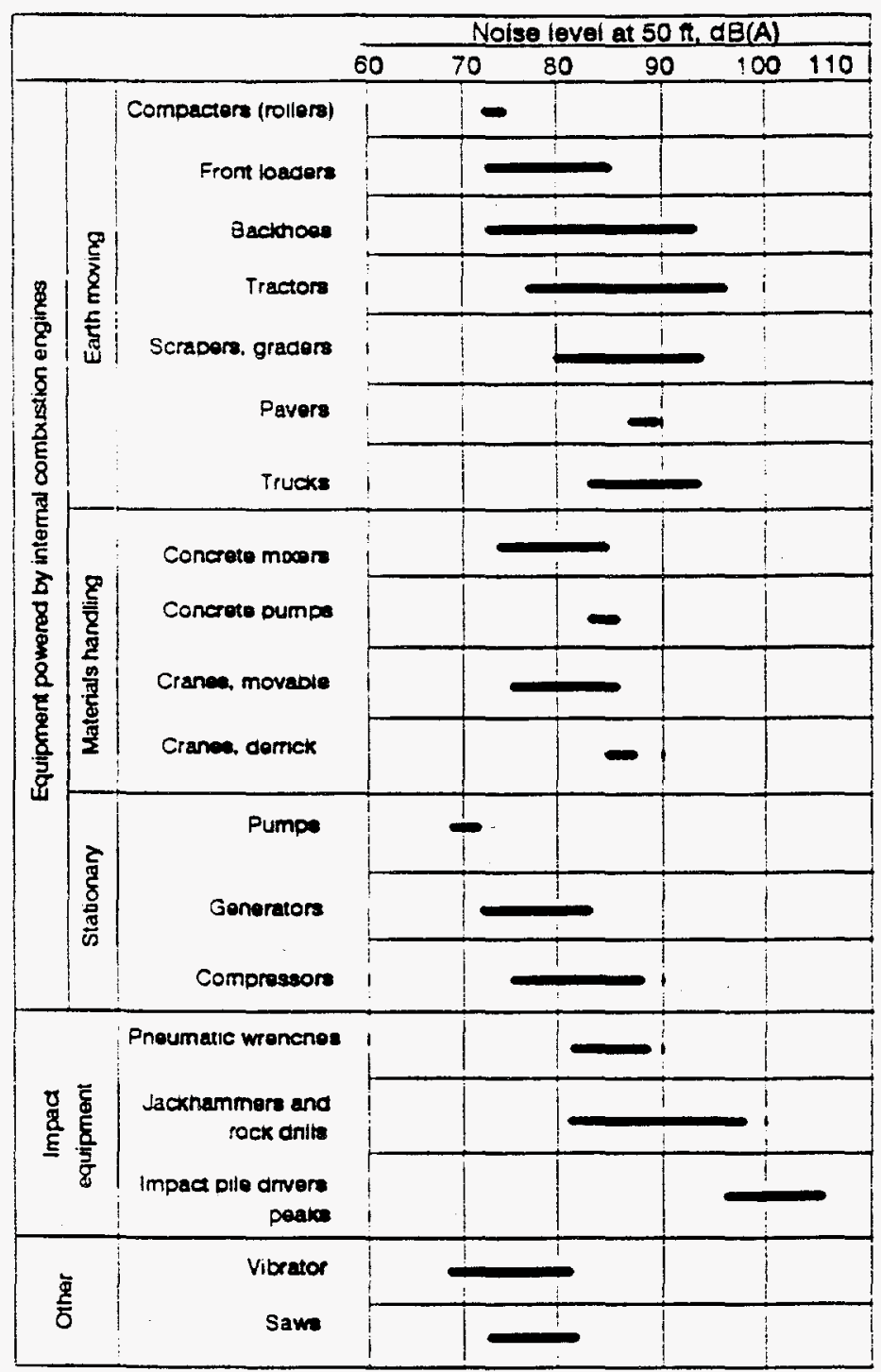

Fig. 5.1. Typical sound level ranges for construction equipment. Source:

Canter, L. W. 1977. Environmental Impact Assessment, McGraw-Hill, New York (based on limited available data samples). 
overall impacts are not expected to be major because construction activities would occur during daylight hours, would not be continuous, and would cease after 21 months.

The boiler building, gas turbine inlet. induced draft (ID) fans, and generator transformers are expected to dominate the noise emissions from the proposed project during operation. The only new equipment that would be located outdoors would be the main and auxiliary transformers, the gas turbine inlet, and ID fans. All other equipment would be indoors. Table 5.4 shows the sound levels predicted for the project sources (Black and Veatch 1993).

Based on the levels shown in Table 5.4, Black and Veatch (1993) modeled the acoustic impact for the surrounding area. Figure 5.2 depicts the predicted sound level contours (24-h $\mathrm{L}_{\mathrm{eq}}$ ) around Warren Station from continuous operation of the facility. The EPA's recommended level to protect against hearing loss is $70 \mathrm{~dB}(\mathrm{~A}) 24-\mathrm{h} \mathrm{L}_{\mathrm{eq}}$. The predicted levels are well below concem for protecting hearing loss. Because these measurements were estimated based on continuous operations (and not intermittent material handling during the day), they are typical of nighttime levels. The acoustic assessment found that the only off-site areas that would experience a nighttime sound level of $45 \mathrm{~dB}(\mathrm{~A})$ or greater would be at a cemetery and a hotel, both located across U.S. Highway 6/62 (see Fig. 5.2). All residences and other sensitive receptors would experience sound levels below $45 \mathrm{~dB}(\mathrm{~A})$ during nighttime hours. The predicted $L_{d n}$ (Black and Veatch 1993) would be $6 \mathrm{~dB}$ greater than the 24-h $\mathrm{L}_{\mathrm{eq}}$ values depicted on Fig. 5.2.' For example, the innermost contour line would represent a $57 \mathrm{~dB}(\mathrm{~A}) \mathrm{L}_{\mathrm{dn}}$ and the outermost contour line would represent a $42 \mathrm{~dB}(\mathrm{a}) \mathrm{L}_{\mathrm{dr}}$. The hotel would

\footnotetext{
${ }^{\mathrm{I}} \mathrm{L}_{\mathrm{m}}=$ day-night weighted sound level. This accounts for the fact that people are more sensitive to noise in the nighttime when background noises are low.
} 
Table 5.4. Predicted sound levels for the proposed project sources

\begin{tabular}{lc}
\hline Source & $\begin{array}{c}\text { Sound level } \\
\mathrm{dB}(\mathrm{A})^{a}\end{array}$ \\
\hline Boiler building & 94 \\
Gas turbine inlet & 103 \\
Induced draft exhaust (with fan silencer) & 109 \\
Generator transformers & 90 \\
\hline
\end{tabular}

"Sound level at the source.

Source: Black and Veatch 1993. Pennsylvania Electric Company, Warren Power Station, Externally Fired Combined Cycle Clean Coal Technology V Demonstration Project-Acoustic Assessment Report, Chemtrics, Inc.

be in the 51-54 dB(A) $L_{d n}$ range. The EPA's recommended level to protect speech communication with an adequate margin of safety is $55 \mathrm{~dB}(\mathrm{~A})\left(\mathrm{L}_{\mathrm{dn}}\right)$ for outdoor residential locations. An outdoor level of 51-54 dB(A) $L_{d n}$ is associated with an indoor $L_{d n}$ of slightly less than $40 \mathrm{~dB}(\mathrm{~A})$, with windows partly open. The nighttime portion of this would be about $32 \mathrm{~dB}(\mathrm{~A})$ which, according to EPA, should in most cases protect against sleep interference (EPA 1974). Therefore, speech and sleep at the hotel should not be adversely affected.

The proposed project would introduce new equipment that would contribute a new, steady, broadband sound source which should blend into the background sound level. The proposed project would not produce appreciable tonal emissions. Two tonal sources typically found at power facilities include ID fans and transformer "hum." The proposed project's ID fans would be equipped with silencers, which would be specially designed to minimize the tonal component. The new transformers would be of such a small size that the hum associated with their operation should not annoy neighboring residents. In summary, noise from the proposed project should not be intrusive or cause disturbance to any sensitive receptors. 


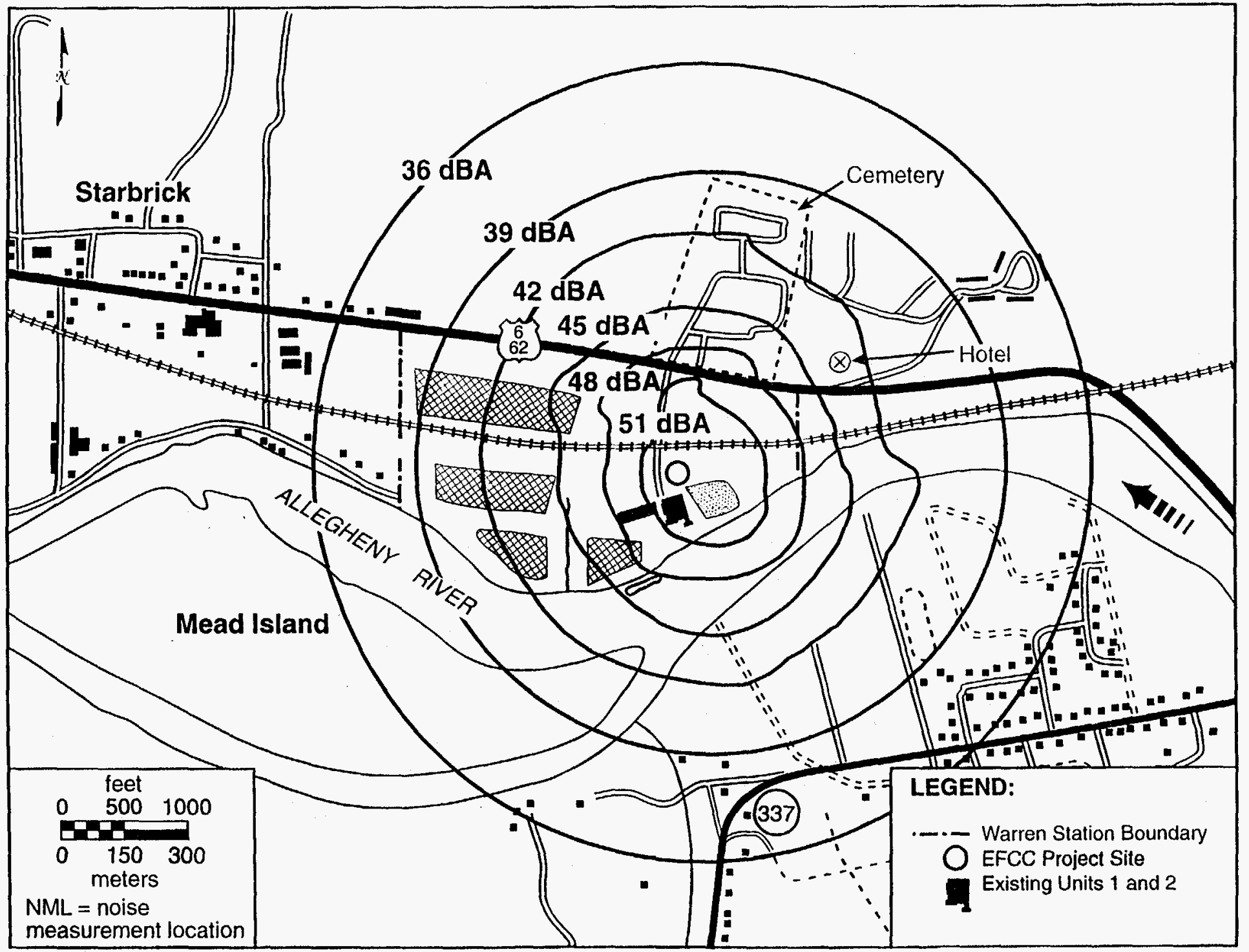

Fig. 5.2. Predicted sound level contours. 


\subsubsection{Electromagnetic Fields}

Electrical substations and transmission lines produce electromagnetic fields (EMFs). Electric fields associated with transmission lines are a function of voltage carried by conductors and the conductor height above ground. Magnetic fields are a function of the amount of current carried by the line and the height of the conductors.

The $110-\mathrm{kV}$ substation used at Warren Station would not need to be upgraded as a result of the new gas turbine's output to the system. The transmission lines and system would also remain the same, except for a new step-up transformer that would be needed to connect the new gas turbine generator to a spare position in the $110-\mathrm{kV}$ substation. There would be some rerouting of on-site transmission lines. All of the rerouting would occur on the Warren Station site on ground already disturbed during the construction of the existing facilities. Connecting the generator to the substation would increase the amount of power being carried by the transmission lines. With an increase in power supply but no change in voltage, the electric field would not change from existing conditions, but the magnetic field would increase proportionately to the increase in power.

Many epidemiological and animal studies have been conducted to assess the health effects associated with EMFs, and findings have pointed in opposing directions. Some studies suggest that exposure to EMFs (such as those found near transmission lines) increases the risk of developing cancer, including childhood leukemia (NSC 1991). The basic nature of the interaction between EMFs and biological processes is still not understood; thus it is considered inappropriate to make generalizations about the exposure-response relationship between EMFs 
and certain cancer outcomes (EPA 1990). Research is ongoing to assess the human health effects of EMFs and to attempt to resolve this scientific debate.

\subsubsection{Human Health and Safety}

Workers would be protected during routine construction activities through compliance with OSHA's Safety and Health Regulations for Construction (29 CFR Pt. 1926). Physical hazards associated with construction of the facility would be considered standard industrial hazards. In 1991, there were approximately 30 disabling injuries (including temporary disabilities, but excluding deaths) for every 1000 workers in the U.S. construction industry. Most accidents in the construction industry result from overexertion, falls, or being struck by equipment (NSC 1992). Assuming the same injury rate at Warren Station, approximately 2 to 6 injuries would statistically be expected to occur out of the 75 to 250 construction workers. Standard construction-related illnesses could also occur (e.g., exposure to chemical substances from spills). No illnesses would statistically be expected to occur from construction activities based on national incidence rates (NSC 1992). Public health would not be threatened by construction activities.

Programs are in place at Warren Station to prevent and minimize public and employee health and safety risks during operation. Penelec has a performance-based comprehensive safety program that covers all aspects of OSHA compliance, employee safety and health, industrial hygiene, fire protection and prevention, and training. In addition, a comprehensive contractor safety program covering nonemployee workers was instituted in 1991. The following programs, which address safe handling and management practices for chemicals and 
spills in the workplace, would continue to be implemented for the proposed project (Black and Veatch 1993):

- Preparedness, Prevention, and Contingency Plan;

- Spill Prevention and Counter Contingency Measures Plan;

- Community Right to Know;

- Hazardous Waste Reporting;

- Storage Tank Registration Program;

- Penelec Ongoing Employee Safety Program;

- Worker Right to Know Program; and

- Industrial Hygiene Program.

The programs are implemented to comply with federal and/or state laws (e.g., the Comprehensive Environmental Response, Compensation, and Liability Act; RCRA; OSHA; and the Pennsylvania Worker and Community Right-to-Know Law).

Potentially hazardous and toxic chemicals used during current operations at Warren Station include caustic soda $(50 \% \mathrm{NaOH})$, hydrazine, and morpholine. For the proposed project, the annual consumption of these substances would either remain the same or decrease. There would be no major change in the handling and use of these substances.

Approximately 33 tons/year of $\mathrm{H}_{2} \mathrm{SO}_{4}$ would be added for the proposed project. Penelec would ensure that airborne exposures resulting from volatilization of $\mathrm{H}_{2} \mathrm{SO}_{4}$ would meet the OSHA permissible exposure limit (PEL), the level below which workers may be exposed day after day without adverse effect. The 8-h time-weighted PEL is an airborne concentration of 
$1 \mu g / \mathrm{m}^{3}$ (29 CFR Pt. 1910.1000). Under normal operating conditions, worker exposures should remain below the PEL. To control potential accidental spills, a 1000-gal tank for storing the $\mathrm{H}_{2} \mathrm{SO}_{4}$ would have secondary containment. The tank would also be inspected and monitored under Penelec's Inspection and Monitoring Program, and the inventory would be reported under the Superfund Amendments Reauthorization Act Title III (also known as the Emergency Planning and Community Right-to-Know Act).

Physical hazards to workers during operation could include (but not be limited to) equipment accidents, noise, heat stress, and confined spaces. All applicable OSHA provisions would be implemented to mitigate safety concerns. For example, noises generated in the power plant buildings are in the $60-90 \mathrm{~dB}(\mathrm{~A})$ range, with exceedances of $90 \mathrm{~dB}(\mathrm{~A})$. Penelec would provide hearing protection to comply with OSHA's PEL of $90 \mathrm{~dB}(\mathrm{~A})$ for occupational exposure.

In general, public health effects can result from exposure to toxic chemicals through various exposure pathways (e.g., airbome exposures, waterborne exposures, direct contact, and food-chain intake). Expected air emissions from the proposed project are described in Sect. 5.1.1. The airbome contaminants include particulate matter, acid gases $\left(\mathrm{SO}_{2}\right.$ and $\left.\mathrm{NO}_{x}\right)$, heavy metals, and organic compounds (e.g., dioxin and benzpyrene). Particulate matter and acid gases can cause respiratory tract irritation in humans, while toxic metals and organic compounds can also cause systemic (e.g., neurological or carcinogenic) effects. Because emissions of particulate matter, acid gases, and organics are expected to decrease, the public should experience no adverse human health effects due to the proposed project. Heavy metals emitted from the coal combustion process include lead, cadmium, arsenic, mercury, selenium, chromium, and nickel. Many heavy metals leave the combustor in a vapor phase and condense 
on or are adsorbed by fly ash and other solid particles. Consequently, these metals are removed from the flue gas during particulate removal. For example, $90 \%$ of lead and cadmium emissions are expected to be removed in the baghouse (ASC 1993). As described in

Sect. 5.1.1.2, annual mercury emissions may increase slightly. However, the change in human exposure to airborne mercury would be negligible.

Impacts are not expected from other exposure pathways such as drinking water, foodchain uptake, and direct contact. In summary, any adverse public health effects from activities related to the proposed project should be negligible.

\subsubsection{Pollution Prevention Measures}

The proposed Penelec project includes pollution prevention measures to minimize the environmental impacts associated with construction and operation of the facilities. These measures are in accordance with the Pollution Prevention Act of 1990, which affirms Congressional commitment to a new approach in improving environmental quality. The act establishes as national policy the following hierarchy of actions for environmental protection:

- prevent or reduce pollution at the source wherever feasible,

- recycle in an environmentally safe manner the pollution that cannot be prevented,

- treat in an environmentally safe manner the pollution that cannot be prevented or recycled, and

- dispose of pollution as a last resort. 
Table 5.5 lists the pollution prevention measures and mitigation measures expected during construction and operation of the proposed project (with a cross-reference to their citation in the text). A key objective of the proposed project is to demonstrate that the EFCC technology would release less emissions to the atmosphere than conventional technology without controls. Table 5.5 shows the substantial reductions of $\mathrm{SO}_{2}, \mathrm{NO}_{x}$, and particulate matter expected with the proposed project.

\subsection{ENVIRONMENTAL IMPACTS OF NO ACTION}

Under the no-action alternative, DOE would not provide cost-shared federal funding to demonstrate the EFCC technology proposed by Penelec. Units 1 and 2 would continue to operate in their existing configuration until their retirement in 5-10 years. These units would require the same amounts of coal, water, and other materials as are currently being used and would generate the same amounts of air emissions, liquid discharges, and solid wastes (see Table 3.1). An exception is that $\mathrm{SO}_{2}$ emissions may increase slightly, contingent upon written approval by PaDER of the proposed $\mathrm{SO}_{2}$ emission limits (see Sect. 3.2). As with the proposed project, Penelec would install liners at the active ash disposal site and ash ponds in 1996 and 1997, respectively (see Sect. 3.2). Environmental impacts would remain the same as the baseline conditions during the existing operation of Warren Station, except that beneficial effects on groundwater quality are expected following installation of the liners. Any change in impacts from the slight increase in $\mathrm{SO}_{2}$ emissions would be negligible. 
Table 5.5. Pollution prevention measures and mitigation measures to be used during construction and operation of the proposed Penelec project

\begin{tabular}{|c|c|c|}
\hline Section & Page & Measure \\
\hline 3.1 .2 .6 & $3-15$ & $\begin{array}{l}\text { During demonstration of the EFCC technology, }{ }^{a} \text { annual } \mathrm{SO}_{2} \text { and } \mathrm{NO}_{\mathrm{x}} \\
\text { emissions would decrease by about } 40 \% \text { and } 16 \% \text {, respectively, from } \\
\text { existing levels at Warren Station. }\end{array}$ \\
\hline 3.1 .2 .6 & $3-15$ & $\begin{array}{l}\text { Annual particulate emissions would decrease by about } 31 \% \text { from } \\
\text { existing levels at Warren Station through the use of a baghouse } \\
\text { employing pulse-jet fabric filters. }\end{array}$ \\
\hline 5.1.1.1 & $5-2$ & $\begin{array}{l}\text { Open construction areas would be sprinkled with water to reduce } \\
\text { fugitive dust emissions by approximately } 50 \% \text {. }\end{array}$ \\
\hline 5.1 .2 .1 & $5-8$ & $\begin{array}{l}\text { Straw berms, liners, cover materials, and grading would be used to } \\
\text { minimize erosion and sediment runoff during construction. }\end{array}$ \\
\hline 5.1.2.1 & $5-8$ & $\begin{array}{l}\text { Accidental spills of construction materials such as solvents, paint, } \\
\text { caulk, oil, and grease would be cleaned up in a timely manner to } \\
\text { prevent runoff into the Allegheny River or seepage into the ground. }\end{array}$ \\
\hline $\begin{array}{l}5.1 .2 .1 \\
\text { and } \\
5.1 .3 .2\end{array}$ & $\begin{array}{l}5-10 \\
\text { and } \\
5-17\end{array}$ & $\begin{array}{l}\text { The amount of ash sluiced to the ash ponds would decrease because } \\
\text { fly ash and scrubber waste from the repowered Unit } 2 \text { would be } \\
\text { trucked directly to the on-site ash disposal facility. An approximate } \\
50 \% \text { reduction in fly ash sluiced to the ash ponds would result in a } \\
\text { proportionate decrease in the amount of trace inorganics that are } \\
\text { discharged into the Allegheny River. }\end{array}$ \\
\hline 5.1 .2 .2 & $5-12$ & $\begin{array}{l}\text { Installation of synthetic liners at the on-site ash disposal facility and } \\
\text { ash ponds would prevent pollutants from leaching into the } \\
\text { groundwater. }\end{array}$ \\
\hline 5.1 .9 & $5-33$ & $\begin{array}{l}\text { The proposed project's induced draft fans would be equipped with } \\
\text { silencers to minimize tonal noise emissions. }\end{array}$ \\
\hline
\end{tabular}

"EFCC = externally fired combined cycle. 


\subsection{ENVIRONMENTAL IMPACTS OF COMMERCIAL OPERATION}

As discussed in Sect. 3.1.2.4, the demonstration of the proposed Penelec project would start in May 1997 and proceed through November 1999. If the demonstration were successful, commercial operation of the project would begin at the end of the demonstration period and continue through the year 2012. Conceivably, the repowered Unit 2 could operate for up to 30 years if the demonstration were successful, but current projections call for it to be retired in 2012. If the demonstration were unsuccessful, the project would be discontinued and Unit 2 would be retired at the end of the demonstration.

Regardless of whether the demonstration is successful, it is expected that Unit 1 will be retired in 5-10 years at the end of its economic life. Subsequently, the 10,500 tons/year of fly ash and bottom ash being sluiced from Unit 1 into the ash ponds and then moved to the South Ash Disposal Site will not be generated. The discharge to the Allegheny River of trace inorganics from the Unit 1 fly ash and heat from the Unit 1 condenser will cease. Several options are being evaluated to dispose of bottom ash, fly ash, and scrubber waste that would be generated by the repowered Unit 2 during the period of commercial operation between the retirement of Unit 1 and 2012 (ASC 1993). The currently preferred option would divide one of the ash ponds into two smaller ponds. The renovated ponds would have liners, leak-detection systems, and monitoring systems that comply with 1992 PRWMRs. The other ash pond would be converted to an ash disposal area to accommodate waste for the remaining life of Unit 2 through 2012. Calculations indicate that the total of this ash pond area and the remaining area at the South Ash Disposal Site would provide the 13 acres of land required to accommodate solid waste disposal through 2012. As in Sect. 5.1.4, the calculations assume a solid waste 
density of $75 \mathrm{lb} / \mathrm{ft}^{3}$ and assume that waste would be piled $36 \mathrm{ft}$ high on average. To provide an upper bound of the volume of solid waste generated, the calculations conservatively assume that Unit 1 would not be retired until 2012.

If Penelec were able to extend the lifetime of the repowered Unit 2 beyond 2012, it would examine its options to accommodate disposal of the additional solid waste. At least two options would be available: (1) Penelec would purchase adjacent or nearby land, obtain necessary permits, and prepare solid waste disposal areas to dispose of the waste on the purchased land; or (2) Penelec would contract with another company for off-site disposal at a permitted solid waste disposal area. In addition, Penelec is interested in finding a commercial market that could use the solid waste (e.g., for use in manufacturing wallboard).

Within a 60-mile radius of Warren Station, there are three solid waste disposal areas with operating permits. The Clarion County Landfill, located about 45 miles south of Warren, should easily accommodate the additional solid waste from the repowered Unit 2 through the year 2027, 30 years after the expected start of the proposed project in 1997 (Tom Badowski, Clarion County Landfill, Leeper, Pennsylvania, personal communication with R. L. Miller, ORNL, Oak Ridge, Tennessee, April 6, 1995). The McKean County Landfill, located about 45 miles east of Warren, is expected to accommodate solid waste until about the 2019-2024 timeframe. Finally, the Lakeview Landfill, located about 60 miles west-northwest of Warren, should have a lifetime lasting until about 2016 to 2031. The latter two locations would be able to accept the solid waste from the proposed project after the on-site disposal areas at Warren Station are filled to capacity, but it is uncertain whether they would have space available through 2027. Regardless, the availability of the Clarion County Landfill ensures that adequate 
off-site disposal would be available if Penelec were able to extend the lifetime of the repowered Unit 2 beyond 2012.

If the repowered Unit 2 were continued commercially, continued public exposure to air emissions would occur for a longer period than if the project were discontinued after the demonstration or if both units were retired in 5-10 years under the no-action altemative. Emissions over longer time periods, if large enough, can contribute to chronic health responses (e.g., $\mathrm{SO}_{2}$ and other pollutants may cause chronic respiratory effects). For Warren Station, however, most emissions during commercial operation would be substantially lower than existing emissions and are not expected to cause any adverse effects. Furthermore, the increased power-generating capabilities of the proposed project would result in decreased use of less efficient units in the Penelec system, which generate more emissions for a given amount of electricity. Therefore, the continued public exposure locally would be offset by a reduction in emissions over the Penelec system.

\subsection{CUMULATIVE ENVIRONMENTAL IMPACTS}

This section evaluates potential environmental impacts from other existing or proposed facilities or activities in the region which, combined with the proposed Penelec project, may contribute to cumulative impacts. The only major emission source in the region that might contribute to cumulative impacts is the United Refinery, located immediately east of the city of Warren. The United Refinery is a major emitter of $\mathrm{SO}_{2}$, particulate matter, $\mathrm{NO}_{x}, \mathrm{VOCs}$, and CO. Existing emissions from the refinery are included as part of the baseline conditions (see Sect. 4.1.2). If any increase in emissions were planned for the future, the United Refinery or 
any new emission source in the area would be required to demonstrate that no additional adverse air quality impacts would be expected (Larry Wonders, Pennsylvania State Bureau of Air Quality Control, Meadville Region, Meadville, Pennsylvania, personal communication with D. A. Lombardi, ORNL, Oak Ridge, Tennessee, January 5, 1994). Emissions from Warren Station would be included in such an analysis to determine overall impacts to the surrounding region. However, the proposed project would reduce most emissions at Warren Station and would lower ambient concentrations of $\mathrm{SO}_{2}, \mathrm{NO}_{x}$, and particulate matter in the region surrounding Warren Station (see Sect. 5.1.1.2). Therefore, replacement of the existing Unit 2 with the proposed project would reduce impacts on the surrounding area, regardless of existing and future emissions from the United Refinery and any new major emission sources that may be constructed in the region.

The United Refinery, located upstream from Warren Station, manufactures oil products and may discharge some organic compounds into the Allegheny River. The proposed project would not increase quantities of the oil and grease discharged to the river by Warren Station. Additional cumulative water quality impacts are not anticipated. Oil and grease are monitored to ensure compliance with the NPDES permit limit.

There are no known projects that in combination with the proposed project would result in appreciable cumulative socioeconomic effects. The project's need for additional coal would provide a continuing source of employment and income for the communities in Pennsylvania where the mines are located. This is a positive effect that may lessen the negative cumulative socioeconomic effects associated with the long-term decline in the Pennsylvania coal mining industry. 


\section{REFERENCES}

ASC (Air Science Consultants, Inc.) 1993. Final Environmental Information Volume, Pennsylvania Electric Company, Warren Station EFCC Demonstration Project at the Warren Generating Station, Warren, Pennsylvania, Warren EFCC, Final EIV, 10-26-93, prepared for Pennsylvania Electric Company, Johnstown, Pa., by ASC, Bridgeville, Pa.

Black and Veatch 1993. Pennsylvania Electric Company, Warren Power Station, Externally Fired Combined Cycle Clean Coal Technology V Demonstration Project-Acoustic Assessment Report, Kansas City, Mo.

Bogan, A. E. 1994. Survey of the Freshwater Bivalves (Mollusca: Unionidae) of the Allegheny River in the Vicinity of the Warren Station Power Plant, Conewango Township, Warren County, PA., Freshwater Molluscan Research, Sewell, N.J., September 26.

Bradish, T. J. 1994. Pennsylvania Electric Company (Penelec), letter to R. A. Bajura, DOE, Morgantown Energy Technology Center, Morgantown, W.Va., January 21.

Carr, K. W. 1994. Chief Division of Archaeology and Protection, Pennsylvania Historical and Museum Commission, letter to K. M. Gray, Penelec, March 15.

COE (U.S. Army Corps of Engineers) 1975. Allegheny River, Pennsylvania (Mile 0 to Mile 72), Final Environmental Impact Statement on the Operation and Maintenance of the Navigation System, U.S. Army Engineer District, Pittsburgh Corps of Engineers, Pittsburgh.

Cowardin, L. M., V. Carter, F. C. Golet, and E. T. LaRoe 1979. Classification of Wetlands and Deepwater Habitats of the United States, FWS/OBS-79/31, U.S. Fish and Wildlife Service, Washington, D.C. 
Warren Station Environmental Assessment

Deutsch, M., et al. 1969. Preliminary Survey of Groundwater Distribution and Potential in the Ohio River Basin, Ohio River Basin Comprehensive Survey Vol. VI, U.S. Geological Survey, Cincinnati.

Dix, E. T. 1994. Pennsylvania Department of Environmental Resources, letter to W. A. Brown, DOE, Morgantown Energy Technology Center, Morgantown, W. Va., August 3.

EPA (U.S. Environmental Protection Agency) 1974. Information on Levels of Environmental Noise Requisite to Protect Public Health with an Adequate Margin of Safety, EPA/550/9-74-004, Washington, D.C., March.

EPA (U.S. Environmental Protection Agency) 1990. Evaluation of the Potential Carcinogenicity of Electromagnetic Fields (review draft). EPA/600-6-90-005A.

EPA (U.S. Environmental Protection Agency) 1991. SCREEN Model User's Guide, Office of Air Quality and Protection, Office of Air Quality Planning and Standards, Research Triangle Park, N.C., November.

EPA (U.S. Environmental Protection Agency) 1992. Environmental Equity, Reducing Risk for all Communities, Vol. 1, Workgroup Report to the Administrator, EPA/230-R-92-008, Washington, D.C., June.

Eyre, F. H. 1980. Forest Cover Types of the United States and Canada, Society of American Foresters, Washington, D.C.

FERC (Federal Energy Regulatory Commission) 1988. Hydroelectric Development in the Upper Ohio River Basin, Ohio, Pennsylvania, West Virginia. Final Environmental Impact Statement, FERC Docket No. EL85-19-114. Federal Energy Regulatory Commission, Office of Hydropower Licensing, Washington, D.C., September. 
Fiedel, S., and J. Klein 1994a. Phase $1 A$ Cultural Resources Survey, Penelec Warren Power Station, Warren County, Pennsylvania, prepared for Black \& Veatch and Pennsylvania Electric Company, by Enserch Environmental Corporation (formerly Ebasco Services, Inc., Environmental Division), January.

Fiedel, S., and J. Klein 1994b. Phase IB Cultural Resources Survey, Penelec Warren Power Station, Warren County, Pennsylvania, prepared for Black \& Veatch and Pennsylvania Electric Company, by Enserch Environmental Corporation (formerly Ebasco Services, Inc., Environmental Division), November.

U.S. Forest Service 1991. Final Environmental Impact Statement for Understory Vegetation Management, Allegheny National Forest, Warren, Pa.

GAI (GAI Consultants, Inc.) 1993a. Ground-Water Assessment Plan for the Warren Generating Station, South Ash Disposal Landfill, Warren County, Pennsylvania, Permit \#300858, Monroeville, Pa. (Appendix F in ASC 1993), May.

GAI (GAI Consultants, Inc.) 1993b. Conceptual Engineering Report, Residual Waste Compliance Project, Monroeville, Pa. (Appendix R in ASC 1993), August.

Gale Research Company 1985. Climates of the States, 3rd ed., Book Tower, Detroit.

Gray, K. M. 1994. Penelec, letter to R. A. Bajura, DOE, Morgantown Energy Technology Center, Morgantown, W. Va., March 30.

Jones, J. R. E. 1964. Fish and River Pollution, Butterworth, London, as cited in Langford 1983, Table 5.2B.

Jutze, G. A., K. Axetell, Jr., and W. Parker 1974. Investigation of Fugitive Dust-Sources Emissions and Control, PEDCo Environmental Specialists, Inc., Cincinnati, prepared for 
the Environmental Protection Agency, Research Triangie Park, N.C., under Contract No. 68-02-0044, Publication No. EPA-450/3-74-036a, June.

Kulp, C. J. 1994. U.S. Fish and Wildlife Service, State College, Pa., letter to W. A. Brown, DOE, Morgantown Energy Technology Center, Morgantown, W. Va., April 4.

Langford, T. E. 1983. Electricity Generation and the Ecology on Natural Waters, Liverpool University Press, Liverpool, England.

Lee, R. D. 1975. Allegheny River Study, Report on Project Number F-39-R (inventory and survey), Fish and Wildlife Service, U.S. Department of the Interior, Washington, D.C.

Lescinsky, J. B., M. B. Coll, Jr., and R. W. Siwicki 1992. Water Resources Data

Pennsylvania, Water Year 1991, Volume 3. Ohio River and St. Lawrence River Basins, U.S. Geological Survey Water-Data Report PA-91-3, National Technical Information Service, Springfield, Va.

Marcy, B. C., and L. M. Thorpe 1976. “The Connecticut River Ecological Study, The Impact of a Nuclear Power Plant," Amer. Fish. Soc., Monograph, No. 1.

McCarren, E. F. 1967. Chemical Quality of Surface Water in the Allegheny River Basin Pennsylvania and New York, U.S. Geological Survey Water-Supply Paper 1835. U.S. Government Printing Office, Washington, D.C.

McDowell, D. A. 1994. Pennsylvania Game Commission, letter to W. A. Brown, DOE, Morgantown Energy Technology Center, Morgantown, W. Va., March 18.

Mitchell, J. F. B. 1989. "The 'Greenhouse' Effect and Climate Change," Rev. of Geophysics 27, 115-139, February.

NSC (National Safety Council) 1991. Accident Facts 1991 Edition, Chicago.

NSC (National Safety Council) 1992. Accident Facts 1992 Edition, Itasca, Ill. 
OECD (Organization for Economic Cooperation and Development) 1983. Coal, Environmental Issues and Remedies, Paris.

PaDER (Pennsylvania Department of Environmental Resources) 1980. Title 25. Rules and Regulations, PART I. Department of Environmental Resources, SUBPART C. Protection of Natural Resources, ARTICLE II. Water Resources, CHAPTER 97. Industrial Wastes, Commonwealth of Pennsylvania, Division of Water Quality, Bureau of Water Quality Management, Meadville, Pa.

PaDER (Pennsylvania Department of Environmental Resources) 1989a. Staff Guidance for Implementation of Temperature Criteria, Commonwealth of Pennsylvania, Division of Water Quality, Bureau of Water Quality Management, Meadville, Pa., October 3.

PaDER (Pennsylvania Department of Environmental Resources) 1989b. Transmittal dated December 29, from Edward R. Brezina, Chief, Division of Water Quality, Bureau of Water Quality Management, to Regional Water Quality Managers, Division Chiefs, Bureau of Water Quality Management, with revised versions of Table 3, page 11, and Examples 1 and 2 from the October 3, 1989, Implementation Guidance for Temperature Criteria, Commonwealth of Pennsylvania, Meadville, Pa. (DER File No. 18-3).

PaDER (Pennsylvania Department of Environmental Resources) 1991. Authorization to discharge under the National Pollutant Discharge Elimination System Industrial Permit Nos. PA 0005053 and 0005053-Amendment No. 1, dated July 24 and August 27, respectively, authorized by D. E. Milhous, P. E., Regional Water Quality Manager, Field Operations-Northwest Region, Commonwealth of Pennsylvania, Division of Water Quality, Bureau of Water Quality Management, Meadville, Pa. (expires July 23, 1996). 
PaDER (Pennsylvania Department of Environmental Resources) 1993a. Pennsylvania Air Quality Report, Report DER \#407-6/93, Commonwealth of Pennsylvania, Harrisburg, Pa.

Regional Economic Information System, Bureau of Economic Analysis 1992. CD ROM on state and county data, April.

Shiels, A. 1994. Pennsylvania Fish \& Boat Commission, Bellefonte, Pa., letter to W. A. Brown, DOE, Morgantown Energy Technology Center, Morgantown, W. Va.

USGS (U.S. Geological Survey) 1981. Warren Quadrangle Pennsylvania-Warren County 7.5 Minute Series Topographic Map, (photorevision of 1954 map), scale 1:24,000, contour interval $20 \mathrm{ft}$, National Geodetic Vertical Datum of 1929, DMA 5167 I SW, Series V831, Denver.

Wetzel, K. L., B. Johnson, and W. Gast 1990. "Pennsylvania Water Supply and Use," pp. 433-440 in National Water Summary 1987-Hydrologic Events and Water Supply and Use, compiled by J. E. Carr, E. B. Chase, R. W. Paulson, and D. W. Moody, U.S. Geological Survey Water-Supply Paper 2350, Books and Open-File Reports Section, Denver.

Zubovic 1976. "Geochemistry of Trace Elements in Coal," in Proceedings: Environmental Aspects of Fuel Conversion Technology, II, December, 1975, Hollywood, Florida. Report EPA 600/2-76-146, Research Triangle Institute, Research Triangle Park, N.C. 


\section{LIST OF AGENCIES AND PERSONS CONSULTED}

Kurt W. Carr

Pennsylvania Historical and Museum

Commission

Bureau for Historic Preservation

Division of Archaeology and Protection

P.O. Box 1026

Harrisburg, PA 17108-1026

Carole Copeyon

U.S. Department of the Interior

Fish and Wildlife Service

Suite 322

315 South Allen Street

State College, PA 16801-4850

Edward T. Dix

Commonwealth of Pennsylvania

Department of Environmental Resources

Bureau of Forestry

P.O. Box 8552

Harrisburg, PA 17105-8552

Charles Fisher

Pennsylvania Department of Revenue

Bureau of Corporation Taxes

Harrisburg, PA 17128-0703

Dan Glotz

Warren County Planning and

Zoning Commission

333 Hickory Street

Warren, PA 16365

Heather Harvey

U.S. Forest Service

Allegheny National Forest

222 Liberty Street

Warren, PA 16239
Nina Huizinga

Department of Environmental Resources

Secretary's Office of Policy

P.O. Box 2063

Harrisburg, PA 17105-2063

Ronald D. Lee

U.S. Department of the Interior

Fish and Wildlife Service

Washington, D.C.

Thomas J. McDonald

New York State Clearinghouse

Division of Budget

State Capitol

Albany, NY 12224

Denver A. McDowell

Commonwealth of Pennsylvania

Pennsylvania Game Commission

Division of Environmental Planning and

Habitat Protection

Bureau of Land Management

2001 Elmerton Avenue

Harrisburg, PA 17110-9797

Christina S. Nagy

Commonwealth of Pennsylvania

Department of Environmental Resources

Bureau of Water Management

Northwest Region

1012 Water Street

Meadeville, PA 16335

Jim Ostergard

Pennsylvania Department of Transportation

Permit Inspector for Warren and

Forest Counties

P.O. Box 985

Warren, PA 16365 
Tom R. Peterson

Pennsylvania American Water Company

Warren, PA 16365

Gerry Pomerantz

U.S. Environmental Protection Agency

Office of Air and Radiation

Research Triangle Park, NC 27709

The Honorable Ernest D. Preate, Jr.

Attorney General

State of Pennsylvania

16th Floor, Strawberry Square

Harrisburg, PA 17120

Andrew L. Shiels

Commonwealth of Pennsylvania

Pennsylvania Fish and Boat Commission

Division of Fisheries Management

450 Robinson Lane

Bellefonte, PA 16823-9685

John Slade

Commonwealth of Pennsylvania

Department of Environmental Resources

Bureau of Air Quality Control

P.O. Box 8468

400 Market St., 12th Floor

Harrisburg, PA 17105-8468
Bill Swartzfager

Pennsylvania Department of Transportation

Traffic Unit for District 10

P.O. Box 985

Warren, PA 16365

The Honorable Dennis C. Vacco

Attorney General

State of New York

New York State Department of Law

State Capitol

Albany, NY 12224

Douglas Wiggins

Seneca Nation of Indians

Environmental Protection Department

1508 Route 438

Irving, NY 14081

Larry Wonders

Commonwealth of Pennsylvania

Department of Environmental Resources

Pennsylvania State Bureau of Air

Quality Control

Meadeville Region

1012 Water Street

Meadeville, PA 16335 
APPENDIX A

FISH SPECIES FOUND IN THE UPPER ALLEGHENY RIVER NEAR WARREN STATION 
Table A.1. Fish species found in the upper Allegheny River near Warren Station

\begin{tabular}{|c|c|c|c|}
\hline Common name & Scientific name & Common name & Scientific name \\
\hline \multicolumn{2}{|c|}{ Game fish } & \multicolumn{2}{|c|}{ Forage fish (cont.) } \\
\hline Muskellunge & Esox masquinongy & Golden shiner & Notemigonus crysoleucas \\
\hline Northern pike & E. lucius & Silver shiner & Notropis photogenis \\
\hline Walleye & Stizostedion vitreum vitreum & Emerald shiner & N. atherinoides \\
\hline Smallmouth bass & Micropterus dolomieui & Rosyface shiner & N. rubellus \\
\hline Largemouth bass & M. salmoides & Sand shiner & N. stramineus \\
\hline Rainbow trout & Salmo gairdneri & Mottled sculpin & Cottus bairdi \\
\hline Brown trout & S. trutta & Longhead darter & Percina macrocephala \\
\hline Brook trout & Salvelinus frontinalis & Gilt darter & P. evides \\
\hline Brown bullhead & Ictalurus nebulosus & Blackside darter & P. maculata \\
\hline Yellow bullhead & I. natalis & Slenderhead darter & P. phoxocephala \\
\hline Channel catfish & I. punctatus & Greenside darter & Etheostoma blennioides \\
\hline Flathead catfish & Pylodictis olivaris & Johnny darter & E. variatum \\
\hline & & Banded darter & E. zonale \\
\hline & & Rainbow darter & E. caeruleum \\
\hline \multicolumn{2}{|c|}{ Panfish } & Fantail darter & E. flabellare \\
\hline & & Spotted darter & E. maculatum \\
\hline Black crapple & Pomoxis nigromaculatus & Bluebreast darter & E. cumurum \\
\hline Wnite crapple & P. annularis & Tippecanoe darter & E. tippecanoe \\
\hline White bass & $\begin{array}{l}\text { Ambloplites rupestris } \\
\text { Morone chrysops }\end{array}$ & $\begin{array}{l}\text { Variegate aarter } \\
\text { Channel darter }\end{array}$ & $\begin{array}{l}\text { E. varicatum } \\
\text { Percina copelandi }\end{array}$ \\
\hline
\end{tabular}

Bluegill

Pumpkinseed

Lepomis macrochirus

Yellow perch

Trout perch

L. gibbosus

Perca flavescens

Percopsis omiscomaycus

\section{Rough fish}

\section{Forage fish}

$\begin{array}{ll}\text { Stonecat } & \text { Noturus flavus } \\ \text { Stoneroller } & \text { Campostom spp. } \\ \text { Madtom } & \text { Noturus spp. } \\ \text { Trout perch } & \text { Percopsis omiscomaycus } \\ \text { Logperch } & \text { Percina caprodes } \\ \text { Longnose dace } & \text { Rhinichthys cataractae } \\ \text { Bluntnose minnow } & \text { Pimephales notatus } \\ \text { Cutlips minnow } & \text { Exoglossum maxillingua } \\ \text { River chub } & \text { Nocomis micropogon } \\ \text { Streamline chub } & \text { Hybopsis dissimilis } \\ \text { Bigeye chub } & \text { Hybopsis amblops } \\ \text { Common shiner } & \text { Notropis cornutus } \\ \text { Mimic shiner } & \text { N. volucellus }\end{array}$

Carp

River quillback

White sucker

Northern hog sucker

Silver redhorse

Shorthead redhorse

River redhorse

Greater redhorse

Black redhorse

Golden redhorse

Ohio lamprey

Allegheny brook lamprey

American brook lamprey

Shortnose gar

American eel

Burbot
Brook stickleback

\author{
Cyprinus carpio \\ Carpiodes cyprinus \\ Catostomus commersoni \\ Hypentelium nigrucans \\ Moxostoma anisurum \\ $M$. macrolepidotum \\ $M$. carinatum \\ $M$. valenciennesi \\ $M$. duquesnei \\ M. erythrurum \\ Ichthyomyzon bdellium
}

Source: Modified from Lee, R. D. 1975. Allegheny River Study, Report on Project Number F-39-R (inventory and survey), Fish and Wildlife Service, U.S. Department of the Interior. 
APPENDIX B

AGENCY CORRESPONDENCE 


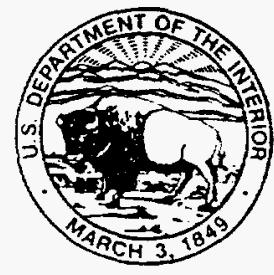

\section{United States Department of the Interior}

FISH AND WILDLIFE SERVICE

315 South Allen Street

State College, Pennsylvania 16801

November 10, 1994

Ms. Wennona A. Brown

Department of Energy

Morgantown Energy Technology Center

P.O. Box 880

Collins Ferry Road

Morgantown, WV 26507-0880

Dear Ms. Brown:

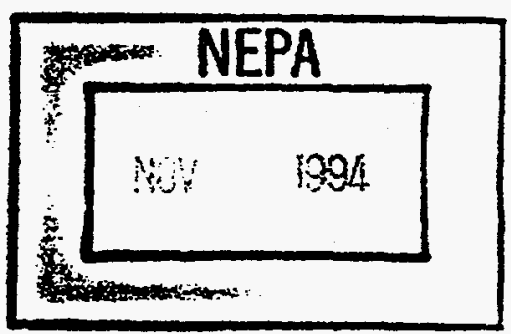

This responds to your October 13, 1994 submission of the "Survey of the Freshwater Bivalves of the Allegheny River in the Vicinity of the Warren Station Power Plant, Conewango

Township, Warren County, Pennsylvania" (prepared by Dr. Arthur E. Bogan) for our review and comment. The following comments are provided pursuant to the Fish and Wildlife Coordination Act (48 Stat. 401, 16 U.S.C. 661 et seq.) and the Endangered Species Act of 1973 (87 Stat. 884 , as amended; 16 U.S.C. 1531 et seq.) to ensure the protection of endangered, threatened and candidate species.

The Service appreciates your willingness to survey this reach of the Alleglieriy fiva tü itis presence of mussel species so that informed management decisions can be made regarding the effluent discharge from Warren Station, as relates to protection of mussel species of special concern. Dr. Bogan's report states that the heated effluent "travels 300 feet in a channel until it meets the head end of a small island and splits, part of the flow goes to the left, directly into the main channel of the Allegheny River, while the rest of the effluent goes down the back channel behind the small island." The effluent travels around both sides of this small island, merging below the small island in the main channel of the Allegheny River. About 300 feet beyond the small island, the main channel of the Allegheny River has been dredged to a depth of $10-20$ feet.

The mussel survey report details the resuits of surveys conducted above, within and below the effluent plume and within the back channel of Mead Island. Note that the effluent plume does not extend into the back channel of Mead Island. In the area above the effluent plume, shells of five mussel species were found, however, only one live individual of one species was located. The area within the effluent plume was mostly devoid of mussels, except for the presence of seven adult individuals of four species within the 300-foot discharge channel; no mussels, live or dead, were found in the area surrounding or below the small island. After circuiting the small island, the effluent follows the main channel of the Allegheny River (which flows to the north of Mead Island), quickly mixing in the dredged zone of the river. No suitable mussel habitat exists in the dredged area, and it is unlikely that the effluent would cause adverse effects to any mussels downstream of the dredged area. No live individuals or shells of either the endangered clubshell (Pleurobema clava) or northern riffleshell mussel (Epioblasma torulosa rangianal were found in any of the above survey areas. 
The area of highest relative mussel diversity is found in the back channel of Mead Island. Due to the flow of the Allegheny River and the location of the outfall, this back channel does not receive effluent from Warren Station. Live individuals of eight mussel species, and shells from three additional species were found in this area. Small individuals of two species were found, indicating that some reproduction is occurring. No live individuals or shells of either the clubshell or northern riffleshell mussel were found, although it appears that suitable habitat for these species occurs in the back channel of Mead Island.

Based on the reported survey results the heated effluent is probably having an adverse effect on the mussel fauna within the effluent plume, extending from the outfall location, around the small island and downstream to the beginning of the dredged area in the main channel of the Allegheny River. Although a few live adult individuals were found, the elevated water temperatures produced by the effluent are likely impairing or preventing mussel reproduction. Other factors, such as the coldwater discharge from Kinzua Dam, effluents from the city of Warren, and dredging of the main channel of the Allegheny River have also contributed to losses in the quality and quantity of mussel habitat in this reach of the Allegheny River.

Because no live or dead individuals of the clubshell or northern riffleshell mussel were found in any of the survey areas, the Service concurs that the Warren Station discharge is not likely to adversely affect these species, therefore, no further Section 7 consultation under the Endangered Species Act is required with the Service. Should project plans change, or if additional information on listed or proposed species becomes available, this determination may be reconsidered. Due to the mussel diversity found in the back channel of Mead Island, the Service would recommend against any future relocation of the Warren Station outfall, especially if the relocation would divert effluent into the back (south) channel of Mead Island.

Again, thank you for your cooperation in conducting this survey. Please contact Carole Copeyon of my staff at 814-234-4090 if you have any questions regarding this matter.

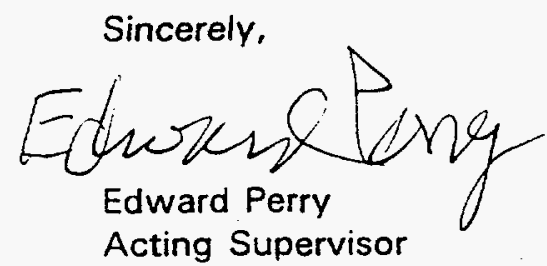




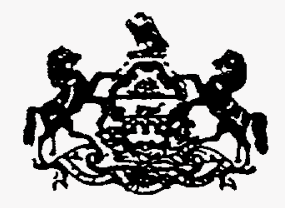

\section{Commonwealth of Pennsylvania \\ Pennsylvania Historical and Museum Commission \\ Burean for Historic Preservation \\ Post Office Box 1026}

Harrisburg, Pennsylvania 17108-1026

December 20, 1994

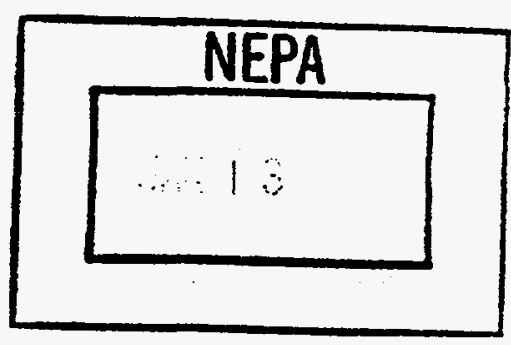

Stuart J. Fiedel, Ph.D.

1290 Wall Street West

P.O. Box 661

Lynähurst, NJ 07071-0661

Re: ER\# 94-1395-123-D

DOE, Unit 2 Repowering Project, PENELEC Warren Power Station, Phase IB Archaeological Survey Report, Warren County

Dear Dr. Fiedel:

The above named project has been reviewed by the Bureau for Historic Preservation (the State Historic Preservation office) in accordance with Section 106 of the National Historic Preservation Act of 1966, as amended in 1980 and 1992, and the regulations ( 36 CFR 800 ) of the Advisory Council on Historic Preservation.

The Bureau for Historic Preservation finds the abovereferenced report meets our standards and specifications. We agree with the recommendations of this report and in our opinion no further archaeological investigation of the project area is necessary.

Please provide 2 copies of this report ( 1 bound, 1 unbound, all with original photographs) for our files. In future submissions please use black and white photographs as color prints are not as stable over time. If you have any questions or comments regarding our review of this project, please contact Andrew Wyatt at (717) 772-0923.

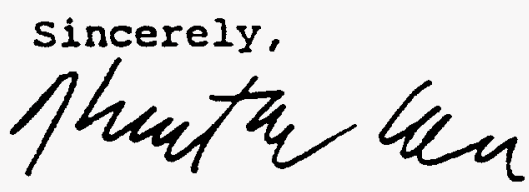

Kurt w. Carr, Chief

Division of Archaeology

CC:Wennona Brown, DOE and Protection

KWC : aW 


\title{
U.S. DEPARTMENT OF ENERGY
}

\author{
MORGANTOWN ENERGY TECHNOLOGY CENTER
}

Finding of No Significant Impact

Warren Station Externally Fired

Combined Cycle Demonstration Project

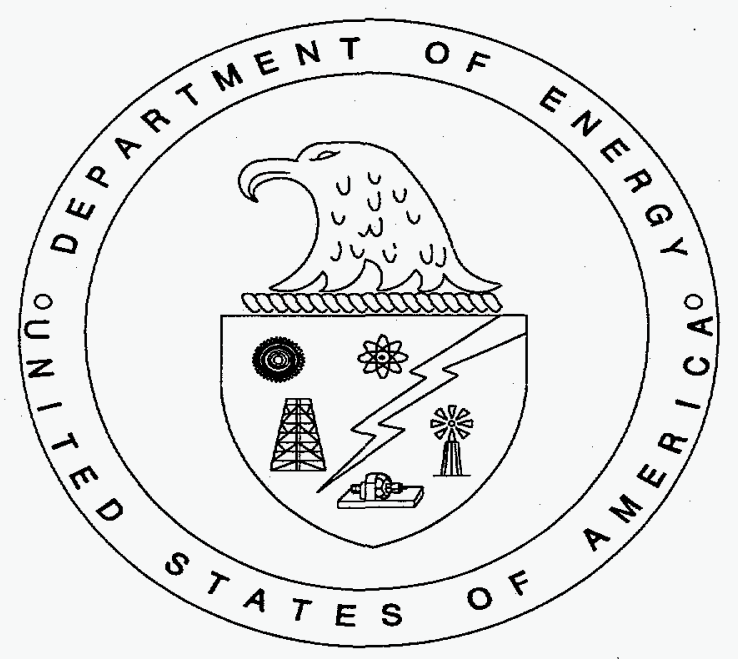

May 18, 1995 


\section{Finding of No Significant Impact}

\section{Warren Station Externally Fired Combined Cycle Demonstration Project}

AGENCY: U.S. Department of Energy

ACTION: Finding of No Significant Impact (FONSI)

SUMMARY: The Department of Energy (DOE) has prepared an Environmental Assessment (DOE/EA-1007) for a project proposed by the Pennsylvania Electric Company (Penelec) to demonstrate externally fired combined cycle technology. The project, subsequently referred to as the Penelec project, would be located at Penelec's existing Warren Station in Warren, Pennsylvania. DOE's proposed action is to provide approximately $\$ 73$ million in federal funding (50 percent of the estimated $\$ 146$ million total cost) for cost-shared design, construction, and demonstration of the Penelec project. The new unit would produce about 73 megawatts of electricity in a combined cycle mode of operation. Based on the analyses in the Environmental Assessment, DOE has determined that the proposed action is not a major Federal action significantly affecting the quality of the human environment, within the meaning of the National Environmental Policy Act (NEPA) of 1969, 42 U.S.C. 4321 et seq. Therefore, the preparation of an environmental impact statement is not required and the Department is issuing this FONSI. 
COPIES OF THE environmental assessment ARE AVAILABLE FROM:

Wennona A. Brown, Environmental Project Manager

Morgantown Energy Technology Center

P.O. Box 880

Morgantown, WV 26507-0880

(304) 285-4294

FOR FURTHER INFORMATION CONTACT:

John R. Ganz, NEPA Compliance Officer

Morgantown Energy Technology Center

P.O. Box 880

Morgantown, WV 26507-0880

(304) 285-4346

\section{SUPPLEMENTARY INFORMATION:}

BACKGROUND: Beginning in December 1985, Congress appropriated funding to DOE for five separate rounds of competitive solicitations under the Clean Coal Technology Program. As a condition of the appropriation, Congress limited DOE's funding to a maximum of 50 percent of the total cost of each project selected. In November 1991, Congress passed Public Law 102-154, which provided $\$ 600$ million to DOE for the fifth solicitation (CCT-V) under the Clean Coal Technology Program. Under CCT-V, DOE solicited proposals for cost-shared demonstration projects that would advance the efficiency and environmental performance of coal-using technologies and that would be applicable to either new or existing facilities. Factors applied in the selection process included the desirability of choosing projects that collectively (1) represent a diversity of methods, technical approaches, and applications; (2) use a broad range of U.S. coals; and (3) are in U.S. locations that represent a diversity of environmental health and safety standards, regulations, and climatic conditions. DOE issued a 
Program Opportunity Notice soliciting proposals to meet this goal in June 1992.

DOE's Source Evaluation Board evaluated the proposals submitted. In May 1993, the source selection official chose five proposals, including the Penelec project, as best furthering the goals and objectives of the solicitation.

The purpose of the proposed Penelec project is to demonstrate that the externally fired combined cycle technology is a viable candidate to meet future energy needs and is an energy-efficient technology capable of reducing emissions of sulfur dioxide, oxides of nitrogen, and particulate matter to meet the post-2000 Clean Air Act Amendments of 1990 standards as outlined by the Clean Coal Technology Program goals. The proposed Penelec project would fill the need for a full utility-size demonstration of the externally fired combined cycle technology as the next step toward commercialization.

DESCRIPTION OF THE PROPOSED ACTION: DOE's proposed action is to provide costshared federal funding to the Penelec project, which would be constructed at Penelec's Warren Station. The station borders the north side of the Allegheny River in Conewango Township, Warren County, about 1 mile west of the City of Warren, Pennsylvania. The current Warren Station has four coal-fired boilers and two steam turbines (Units 1 and 2) that each produce 48 megawatts for a station total of 96 megawatts of electricity. The Penelec project would repower steam turbine Unit 2. The demonstration period of the proposed project is expected to start in May 1997, 
and continue for 30 months. Following the demonstration period, Penelec expects to operate the repowered Unit 2 as a commercial unit through the year of 2012. However, the expected life of the repowered Unit 2 could be up to 30 years. If the unit is operating satisfactorily, Penelec may choose to continue commercial operation beyond the year of 2012 .

Technology Description: For the project, a new "power island" would replace two existing boilers and integrate with the existing Unit 2 steam turbine, its electric generator, and the stack, which would be raised from 200 feet to 312 feet. New "power island" equipment includes a staged coal combustor, slag screen, ceramic heat exchanger (ceramic heat exchanger), indirectly fired gas turbine and electric generator, heat recovery steam generator (heat recovery steam generator), lime silo, flue gas desulfurization dry scrubber, and baghouse. Unit 2 would then operate in a combined-cycle mode using the new gas turbine and the existing steam turbine simultaneously, thus increasing Unit 2 output from 48 megawatts to 73 megawatts (gross), yielding a new station total of 121 megawatts of electricity.

The repowered Unit 2 is expected to achieve an approximate 50 percent increase in maximum power generation with the externally fired combined cycle technology (73 megawatts versus 48 megawatts) with a 90 percent sulfer dioxide removal efficiency. Because the externally fired combined cycle 
technology is more efficient, this increase in power generation would be achieved using nearly the same amount of coal per hour as the existing Unit 2. However, annual operating time for the repowered Unit 2 is expected to increase by about 60 percent over that for the existing Unit 2 .

During operation, pulverized coal (25 tons per hour) would be fed into a new three-stage combustor, under controlled conditions to limit oxides of nitrogen emissions and optimize carbon burn-out, thus lowering carbon monoxide emissions. The hot combustion gas exits the lower section of the combustor and enters a slag screen, which is composed of an array of ceramic rods. As the combustion gas flows through the slag screen, ash particles larger than 10 microns impact and stick to the ceramic rods, which are then periodically cleaned of the ash buildup.

The hot combustion gas exits the slag screen and enters the ceramic heat exchanger, which is the central feature of the externally fired combined cycle technology. Here, the combustion gas heats ceramic tubes containing outside pressurized air. This creates a clean, hot, pressurized air stream that is expanded through a new gas turbine to generate 25 megawatts of electricity. By using this indirectly heated air, turbine components are protected from the corrosive and abrasive substances in the combustor exhaust gas. For added efficiency, the exhaust air from the gas turbine is returned to the combustor as 
preheated air. Hot combustion gas discharged from the ceramic heat exchanger enters the heat recovery steam generator where it is used to generate steam, which is then expanded in the existing steam turbine (Unit 2) to generate 48 megawatts of electricity. Combustion gas exiting the heat recovery steam generator enters the flue gas desulferization dry scrubber where it reacts with lime to form calcium sulfate and calcium sulfite, which are removed at the bottom of the scrubber. The gas then passes through the pulse-jet fabric filter baghouse to remove any remaining particulate matter, before exiting the stack.

Facility Inputs: Materials and resources required by the proposed project include an increase in coal from 115,300 tons for the existing Unit 2 to 185,500 tons for the repowered Unit 2, which when added to the requirements for Unit 1 $(114,100$ tons) would yield a new station total of 299,600 tons per year. Water requirements would include 58,800 gallons per minute withdrawn from the Allegheny River for the condensers (no change from current use); however, a decrease in sluice water to the ash ponds would result because the fly ash from Unit 2 would be dry and transported directly to the ash disposal area. An additional 53 gallons per minute of water for the flue gas desulferization scrubber would be required; the Unit 2 evaporator requiring 18 gallons per minute would be replaced by a demineralizer requiring an additional 72 gallons per minute from the Pennsylvania American Water Company (PAWC). Approximately $14,000,000$ cubic feet per year of natural gas would be used 
during testing and startup of the combustor and gas turbine the first year and decreasing in subsequent years. Other new materials required include 10,000 tons per year of lime for the flue gas desulferization scrubber, and 33 tons per year of sulfuric acid (equivalent to 5,110 gallons) and 135 tons per year of sodium hydroxide for the demineralizer. Annual use of hydrazine (40 gallons), sodium phosphate ( 80 gallons), and morpholine ( 200 pounds) in the boiler feedwater treatment system would remain unchanged. Aluminum sulfate usage to clarify house water would increase to 1.5 tons per year ( 50 percent increase), but bentonite clay and rock salt use would each decrease 50 percent.

ENVIRONMENTAL IMPACTS: Impacts to the environment associated with both construction and operation of the proposed demonstration project were considered. Detailed analyses in the Environmental Assessment focused on the expected level of impacts associated with atmospheric resources, water resources, and waste management. The remaining topics were analyzed to a lesser extent, commensurate with the potential for impacts on the resource area. Review of the available environmental information indicates that no significant environmental impacts are expected to occur as a result of the proposed project.

Impacts of Construction: The proposed project's 21-month construction period is expected to begin in August 1995. Employment of construction workers would 
last about 18 months with a work force ranging from 75 to 250 workers, peaking in 1996.

The proposed project would be constructed at Penelec's Warren Station on approximately 1 acre, with an additional 5 acres used for construction laydown. All project construction, including associated buildings and equipment, would occur within the existing 96 -acre plant boundaries. Most of the externally fired combined cycle components would be housed in a new addition adjoining the existing building housing Units 1 and 2, which was constructed in 1948. A new water treatment facility would adjoin this new addition. New generator transformers would be located near the existing substation. The project would use the existing coal storage and receiving facilities, with an extension from the existing coal-handling system to the new equipment. No land acquisition would be necessary for the proposed project.

Air quality effects of construction would be limited to temporary and localized fugitive dust and vehicular/equipment exhaust fumes, thus resulting in minimal impacts to air quality during the construction period. No impact to surface water or groundwater is anticipated from project construction. Also, project construction (and operation) would occur above the 500-year floodplain and would not disturb the existing wetland; therefore, no impacts on these resources are expected. 
The small acreage affected by construction activities has been previously disturbed and has no important plant or animal resource. Construction would not affect the relatively undisturbed habitats on the site. Erosion and sediment control measures and prompt cleanup of accidental spills would minimize the movement of these substances into the river; therefore, these materials would not affect water quality or aquatic species. Construction activities would have minimal impacts on terrestrial and aquatic species; therefore, the impact on biodiversity would be negligible. No prime farmland is located on the Warren station site. No off-site impacts on land use are expected during construction.

Construction wastes such as wood, cardboard, and glass are transported to the McKean County landfill, which has sufficient unfilled capacity for these wastes. Licensed contractors handle and dispose of solvents, waste oils, fuel oil spills, and other miscellaneous liquid wastes in accordance with federal and state liquid waste regulations. Quantities of liquid wastes generated during construction and operation of the proposed project would not add appreciably to the quantities now being produced at Warren Station (approximately one 55gallon drum per month).

An ongoing archaeological investigation has identified significant occupations near the eastern boundary of the Warren Station site. Construction of the proposed project would not affect this site. A cultural resources survey was 
performed on the areas to be disturbed by construction and laydown, and further testing was done on part of the proposed laydown areas as recommended by the study. One proposed laydown area was removed from consideration because of its proximity to the archaeological site. The survey and testing of these areas indicated extensive prior disturbance. No prehistoric or historic remains were found, and no additional work was recommended. The Pennsylvania Bureau for Historic Preservation reviewed and concurred with the survey recommendations.

Construction of the proposed project would have little or no effect on aesthetics, noise or human health and safety. The most visible structure on site is the 200 -foot stack, which would be raised to 312 feet. The new buildings and raised stack would be aesthetically compatible with the existing power plant, which is a long-time feature of the area. Ambient noise levels would increase temporarily in the immediate vicinity of the Warren Station, but are not expected to be major because construction activities would occur during daylight hours. Physical hazards associated with construction of the facility would be considered standard industrial hazards. Public health would not be threatened by construction activities.

Impacts of Operation: The demonstration period of the proposed project is expected to last for 30 months, beginning in May 1997. During the 
demonstration, annual air emissions from the repowered Unit 2, as compared with the existing Unit 2, are expected to decrease by 79 percent for sulfer dioxide, 32 percent for oxides of nitrogen, 62 percent for particulate matter, and 27 percent for volatile organic compounds, but increase by 71 percent for carbon dioxide. Combined operation of the repowered Unit 2 and the existing Unit 1 (total station operations) are also expected to show decreases in air emissions and ambient air concentrations of criteria pollutants (sulfer dioxide, oxides of nitrogen, and particulate matter), except for carbon dioxide which would increase by 36 percent (equivalent to 0.0001 percent of the annual total emitted by global fossil fuel combustion). However, due to increased operating time of the repowered Unit 2, annual mercury emissions, which parallel the amount of coal burned, would increase from 32 grams to 43 grams. These emissions are small and would result in ground-level concentrations well below Environmental Protection Agency's mercury guideline. Ambient concentrations of other pollutants, including air toxics, resulting from the proposed project should be minimal. On an overall basis, the proposed project is expected to improve the air quality of the surrounding region.

Water consumption would increase by 107 gallons per minute during operation of the proposed project. About two-thirds of this would come from the PAWC, with the remainder from the Allegheny River. No groundwater would be withdrawn directly by Penelec for the proposed project. Groundwater usage 
would be indirect as supplied by PAWC which currently has excess capacity. The increased withdrawal from the river would negligibly impact its flow because of the regulated minimum flow of 224,000 gallons per minute from Kinzua Dam.

Discharges from Warren Station to the Allegheny River include non-contact cooling water and clarified water from the ash ponds. Once-through cooling water is withdrawn from the Allegheny River, run through the condensers at the rate of 58,800 gallons per minute, and returned to the river at the north bank. The proposed project would not affect this rate nor the temperature of the discharge. The thermal plume resulting from the heated effluent discharge would not change in areal extent. However, the repowered Unit 2 is expected to operate 60 percent more of the time than the original Unit 2, which would result in the discharge occurring over a more prolonged period of time. An analysis was performed using a steady-flow energy balance that accounts for the heat that the proposed facility would reject to the river. Even though the larger main channel is to the north of Mead Island, a conservative analysis was used which presumed the 10-year, 7-day low flow $(260,000$ gallons per minute) was equally divided by Mead Island. The analysis showed that water temperatures in the main channel would occasionally exceed 87 degrees Fahrenheit and could reach a maximum of 91 degrees Fahrenheit. However, temperatures exceeding 87 degrees Fahrenheit would rarely be reached because 
the majority of the river's flow is to the north of Mead Island and the annual average flow above Warren Station (as evidenced by data during the years of 1989-1991) was 3,068,000 gallons per minute.

Two ash ponds currently discharge 1,600 gallons per minute of supernatant into the Allegheny River in accordance with National Pollutant Discharge Elimination System permit limitations. The ash ponds receive inflow from the ash sluicing system (bottom ash and fly ash), runoff from the ash disposal area, neutralized coal pile runoff, neutralized demineralizer wastewater, and plant general sump collections. The discharge from the ash ponds is expected to decrease as a result of the proposed project because the fly ash from Unit 2 (50 percent of the total produced) would be a dry waste taken directly to the ash disposal area. The amount of trace inorganics released from the ash ponds would correspondingly decrease 50 percent because of the reduction in fly ash entering the ash ponds.

Under the new requirements of Pennsylvania Department of Environmental Resources for waste disposal, Penelec plans to place liners at the active ash disposal site and ash ponds in the year of 1996 and 1997 respectively. The ash disposal area would be lined prior to start of the proposed project. The installation of liners at the facilities should is designed to constituents from leaching into groundwater. Reduced impacts are expected because groundwater 
quality would improve after Penelec meets the new disposal requirements. Because the increased coal consumption would change only the number of truckloads per week and not increase the size of the storage area, no change in impacts to groundwater is anticipated from coal pile runoff.

The quantity of solid waste generated annually at Warren Station would increase from about 21,000 tons to about 45,700 tons. The solid waste would be comprised of fly ash, bottom ash, and scrubber residuals. Except for scrubber residuals, the on-site landfill is permitted for disposal of these wastes in addition to pyritic refuse, coal pile drainage sludge, asphalt, stones, rock, concrete, brick and soil. The solid waste resulting from the annual cleaning of the ash ponds is also transported to the on-site landfill for disposal. The externally fired combined cycle scrubber residuals, consisting of hydrated calcium sulfite, calcium sulfate, calcium hydroxide and various inert solids could also be disposed in the on-site landfill with permit modification. The capacity of the on-site landfill would accommodate the increased solid waste during the project demonstration period. Continued operation as a commercial unit through the year of 2012 would also be accommodated on site by converting one of the ash ponds for solid waste disposal. If Penelec chooses to continue operation beyond the year of 2012 , disposal would be accommodated through purchasing and permitting additional land for disposal or transporting the waste to a commercial landfill. There are currently several permitted 
landfills within a 60-mile radius of Warren Station that have capacity for the solid waste.

Impacts to ecological resources are not expected to change with operation of the proposed project. Operation of the proposed project would not cause appreciable changes in land use or terrestrial habitats on the Warren Station; the area used for ash disposal activities is expected to increase only slightly. Any effect on terrestrial plant and animal resources resulting from noise and air emissions from project operation would be negligible. Withdrawal of an additional 35 gallons per minute from the Allegheny River represents about a 0.06 percent increase, which is expected to result in only a slight increase in impingement or entrainment of aquatic organisms. The water temperature in the outfall channel and the narrow channel close to the north shore currently exceeds the 85 degrees Fahrenheit - 88 degrees Fahrenheit maximum thermal tolerance of aquatic species in the area occasionally. Because the thermal plume extends downstream on the north side of the main channel only and cools rapidly, aquatic species preferring cold-water habitats can avoid the plume by staying in the unaffected portion of the main channel. No incidents to aquatic life have been reported as a consequence of the existing thermal plume in over 40 years of Warren Station operation. No appreciable change is expected from increased annual exposure of the aquatic species to the thermal plume. 
The Allegheny River in the vicinity of Warren Station is within the range of two federally endangered species, the northern riffleshell and clubshell mussels. Also the state protected Ohio lamprey, tippecanoe darter, bluebreast darter and channel darter may occur in the vicinity of Warren Station. A mussel survey conducted in the area found no endangered species; however, several nonendangered mussel species were found in the river channel south of Mead Island and in the outfall channel itself. Protected fish species and the Ohio lamprey, which may occur in the river, should be able to avoid the thermal plume. Therefore, the proposed project would have no impact on threatened or endangered species. The U.S. Fish and Wildlife Service has concurred with this finding.

The principal socioeconomic effects from the proposed project would be increased traffic during construction and operation and increased taxes paid by Warren Station. Increased delivery of coal from 210- to 280- trucks per week would be accommodated by increasing the number of delivery days, rather than the number of trucks per day; therefore, no impact on traffic is anticipated. To the extent that this project would allow Warren Station to continue operating, it would sustain the existing employment and income benefits and help stabilize declining population levels. Only 0.6 percent of Warren County's population is non-white. Also, while average income in Warren County is somewhat lower than for the United States or the Commonwealth of Pennsylvania, the county 
also has a lower rate of households with income below the poverty level. This suggests that any effects from the project within Warren County would not adversely and disproportionately impact minority or low-income groups.

Operation of the proposed project would have no effect on cultural resources, aesthetics, noise or human health and safety. The proposed project would introduce new equipment that would contribute a new, steady, broadband sound source which should blend into the background sound level. Because emissions of particulate matter (including adhered heavy metals), acid gases, and organics are expected to decrease, the public should experience no adverse human health effects from airborne emissions due to the proposed project. Impacts are not expected from other exposure pathways such as drinking water, food-chain uptake, and direct contact.

There are no known projects that in combination with the proposed project would result in appreciable cumulative effects. Replacement of the existing Unit 2 with the proposed project would reduce air quality impacts on the surrounding area, regardless of existing and future emissions from the nearby United Refinery and any new major emission sources that may be constructed in the region. Additional water quality impacts are not anticipated. 
Alternatives to THE PROposed aCtion: Alternatives to the proposed action include alternative technologies, alternatives sites, and the no-action alternative. In the Environmental Assessment, only the proposed action and the no-action alternatives were considered. Given the nature of the Clean Coal Technology selection process, DOE is limited to either accepting or rejecting a selected demonstration project as proposed by the participant, including the proposed technology and site. Therefore, the only technology and site addressed in the Environmental Assessment are those proposed by Penelec.

Under the no-action alternative, DOE would not provide cost-shared federal funding to demonstrate the externally fired combined cycle technology proposed by Penelec. Without DOE participation, the Penelec project would be canceled, and the technology would not be demonstrated elsewhere because there are no other similar projects in the Clean Coal Technology Program. If the project were canceled, the new equipment would not be installed at Warren Station, and the facility would continue to operate without change. Project cancellation would result in the project not contributing to the objectives of the Clean Coal Technology program.

PUBLIC OUTREACH: In accordance with DOE's regulations implementing NEPA (10 CFR 1021.301), DOE sent copies of the pre-approval Environmental Assessment to the states of Pennsylvania and New York and the Seneca Nation for review and comment in February 1995, prior to final approval. On February 22 and 25, 1995, DOE also 
published a notice in the Warren Times Observer, a newspaper of general circulation in Warren County, Pennsylvania, that copies of the pre-approval Environmental Assessment were available for review and comment, either upon request from DOE or at local public reading rooms for a period of 30 days. Copies of the final Environmental Assessment and the FONSI will be distributed to all persons and agencies known to be interested in or affected by the proposed action or alternatives, including appropriate agencies in the states of Pennsylvania and New York, and the Seneca Nation. Additional copies of the Environmental Assessment and FONSI are available on request from the Morgantown Energy Technology Center at the address given above. 
DETERMINATION: Based upon the information and analyses provided in the Environmental Assessment, DOE has determined that the proposed Penelec project titled "Warren Station Externally Fired Combined Cycle Demonstration Project" at Warren, Pennsylvania is not a major Federal action significantly affecting the quality of the human environment within the meaning of NEPA. Therefore, an Environmental Impact Statement is not required.

ISSUED IN MORGANTOWN, WEST VIRGINIA, THIS 18 TIMDAY OF 1999

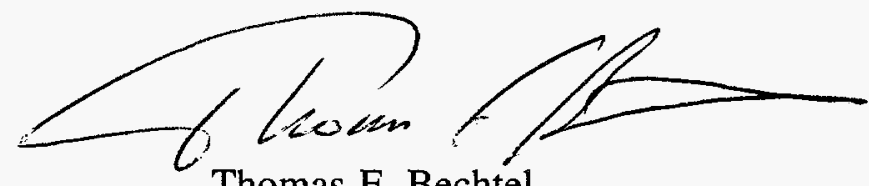

Thomas F. Bechtel

Director

Morgantown Energy Technology Center U.S. Department of Energy 